
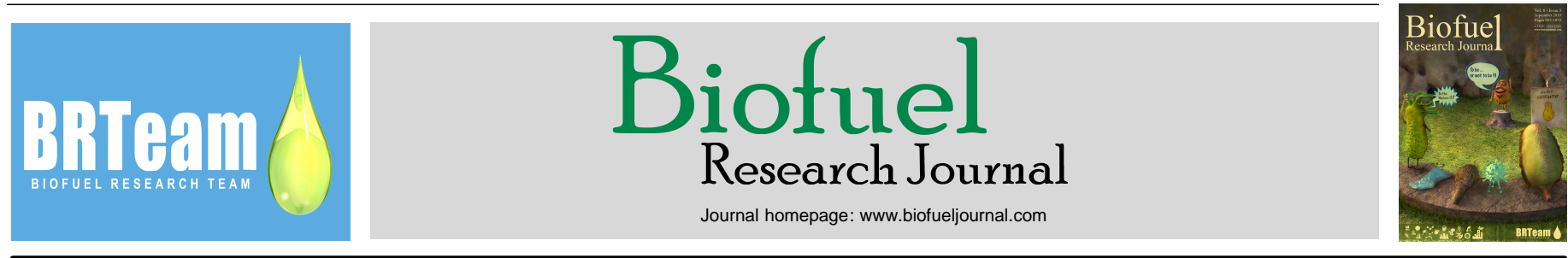

Review Paper

\title{
A review on green liquid fuels for the transportation sector: a prospect of microbial solutions to climate change
}

\author{
Hamed Kazemi Shariat Panahi ${ }^{1,2}$, Mona Dehhaghi ${ }^{1,2}$, James E. Kinder ${ }^{3}$, Thaddeus Chukwuemeka Ezeji ${ }^{3, *}$
}

${ }^{1}$ Faculty of Medicine and Health Sciences, Macquarie University, NSW, Australia.

${ }^{2}$ Department of Microbial Biotechnology, School of Biology and Centre of Excellence in Phylogeny of Living Organisms, College of Science, University of

Tehran, Tehran, Iran.

${ }^{3}$ Department of Animal Sciences, Ohio State Agricultural Research and Development Center (OARDC), The Ohio State University, Wooster, USA.

\section{HIGHLIGHTS}

$>$ Microbial-based biofuel as a promising waste-toenergy technology has been scrutinized.

$>$ Microbial production of bio-jet fuel is possible through DSHC, AtJ, and GtL.

$>$ Future application of ammonia as bio-fuel requires special design of ICE.

$>$ Cons and pros of microbial liquid fuels over gasoline have been outlined.

$\rightarrow$ Conversion of microbial liquid fuel into fuel

derivatives has been discussed.

\section{GRAPHICAL ABSTRACT}

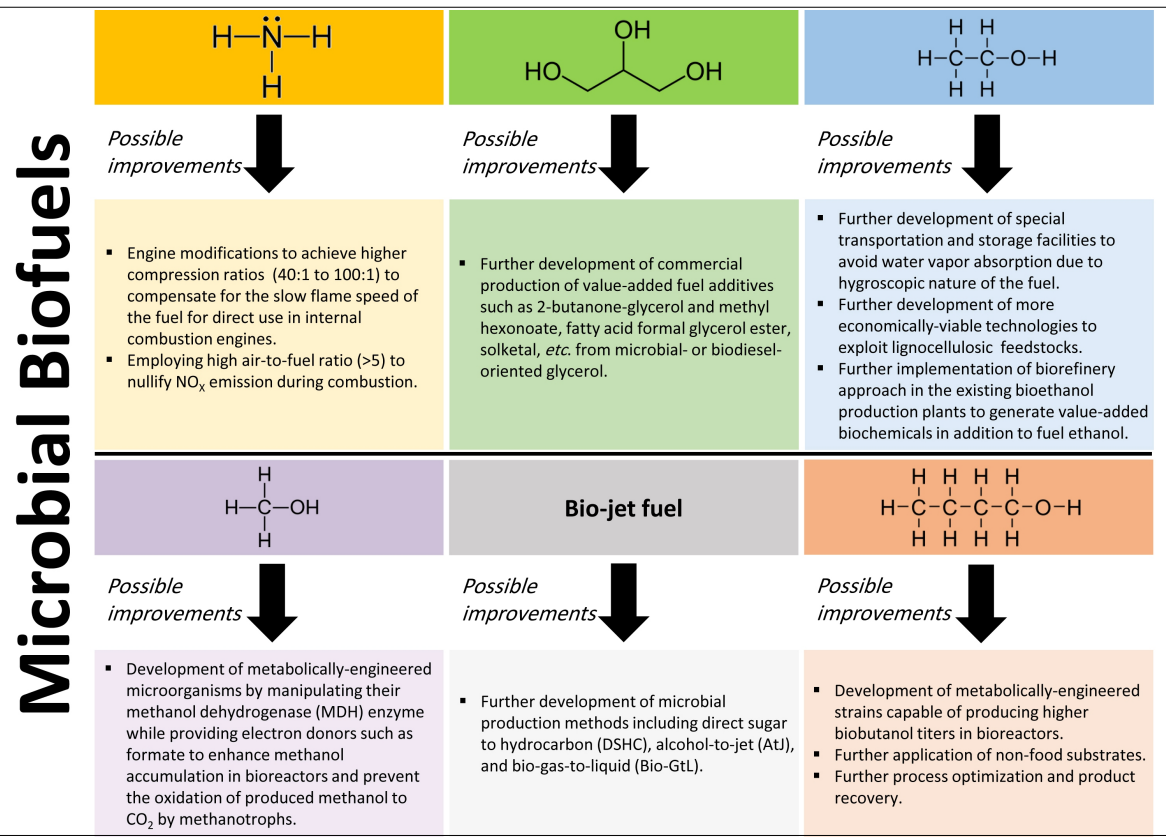

\section{ARTICLE INFO}

Article history:

Received 12 July 2019

Received in revised form 18 August 2019

Accepted 20 August 2019

Available online 1 September 2019

\section{Keywords:}

Biofuel

Microbial metabolite

Bioethanol

Biobutanol

Bio-jet fuel

Sustainable energy

Fuel additive

\begin{abstract}
Environmental deterioration, global climate change, and consequent increases in pollution-related health problems among populations have been attributed to growing consumption of fossil fuels in particular by the transportation sector. Hence, replacing these energy carriers, also known as major contributors of greenhouse gas emissions, with biofuels have been regarded as a solution to mitigate the above-mentioned challenges. On the other hand, efforts have been put into limiting the utilization of edible feedstocks for biofuels production, i.e., first generation biofuels, by promoting higher generations of these eco-friendly alternatives. In light of that, the present review is aimed at comprehensively assessing the role and importance of microorganisms such as bacteria and yeasts as catalysts for sustainable production of liquid biofuels including bioethanol, biomethanol, biobutanol, bio-ammonia, biokerosene, and bioglycerol. Various aspects of these biofuels, i.e., background, chemical synthesis, microbial production (including exploitation of wild and metabolically-engineered species), and product recovery as well as the derivatives produced from these biofuels which are used as fuel additives are thoroughly covered and critically discussed. Furthermore, the industrial features of these green liquid fuels including the industrial practices reported in the literature and the challenges faced as well as possible approaches to enhance these practices are presented.
\end{abstract}

(C) 2019 BRTeam. All rights reserved.

* Corresponding author at: Tel.: +1-330-263-3796

E-mail address: ezeji.1@osu.edu

Please cite this article as: Kazemi Shariat Panahi H., Dehhaghi M., Kinder J.E., Ezeji T.C. A review on green liquid fuels for the transportation sector: a prospect of microbial solutions to climate change. Biofuel Research Journal 23 (2019) 995-1024. DOI: 10.18331/BRJ2019.6.3.2 


\section{Contents}

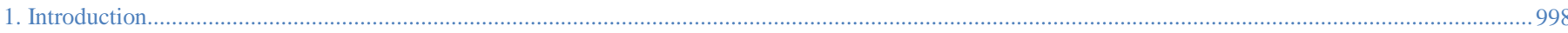

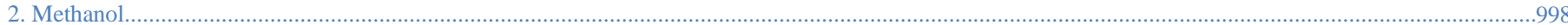

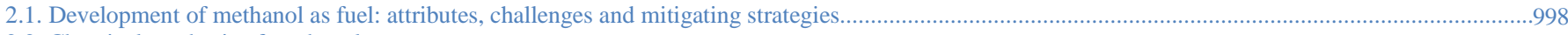

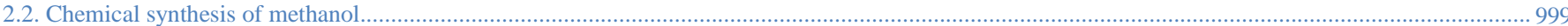

2.3. Biological production of methanol: significance of $\mathrm{CH}_{4}$ in methanol-producing microorganisms............................................................................1000

2.4. Methanol derivatives as fuel components: production, application, and performance........................................................................................... 1001

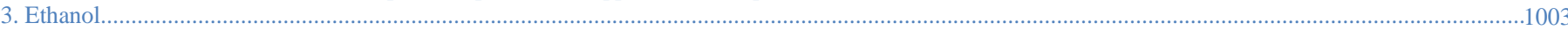

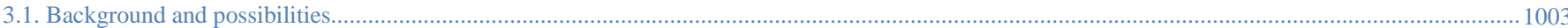

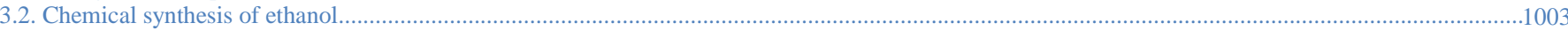

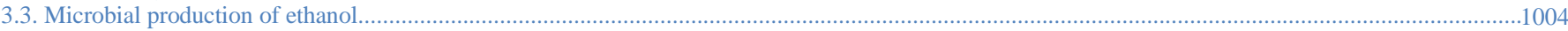

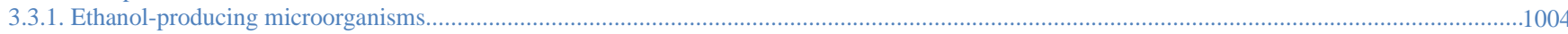

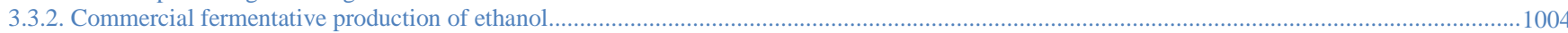

3.4. Ethanol derivatives as fuel components: production, applications, and performance

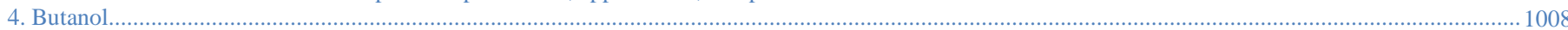

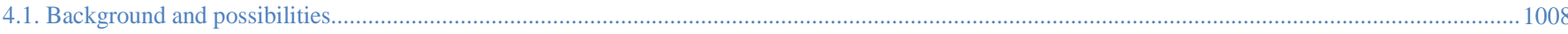

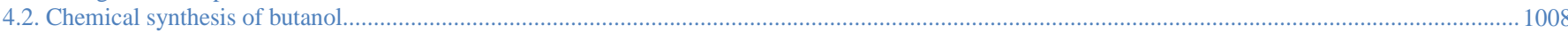

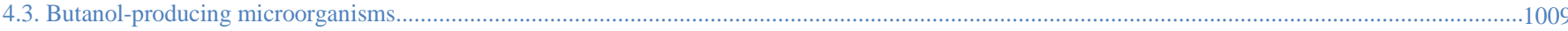

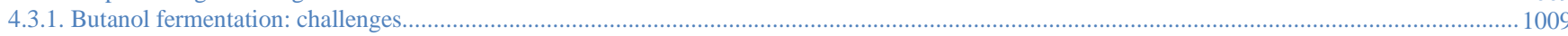

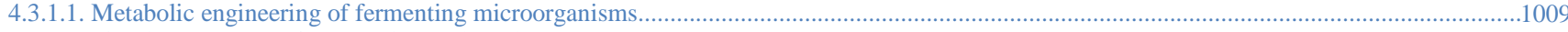

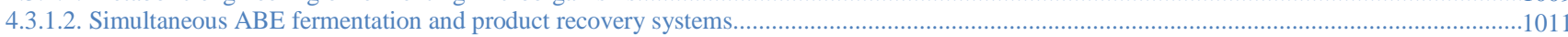

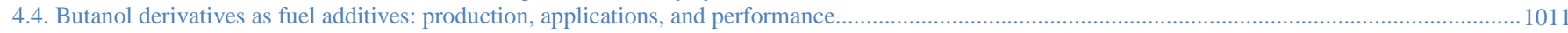

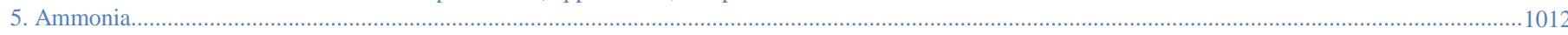

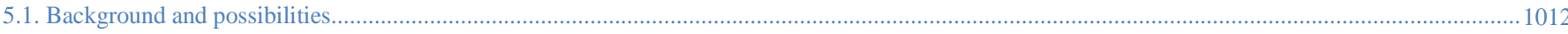

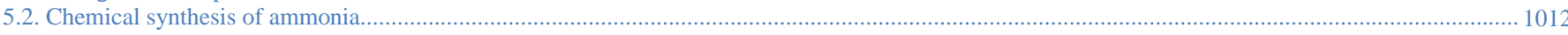

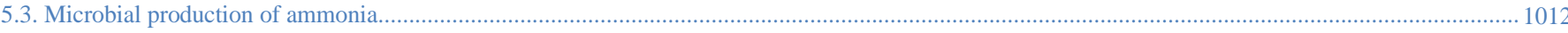

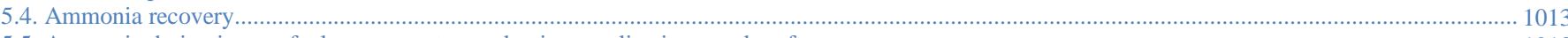

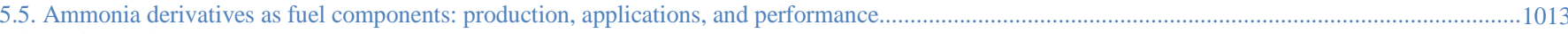

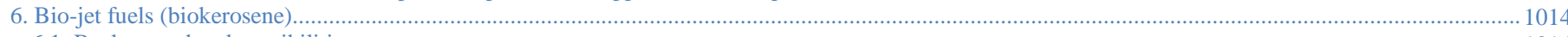

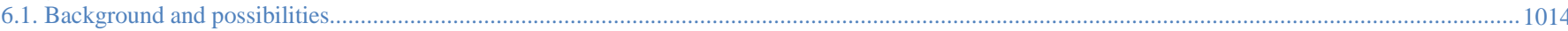

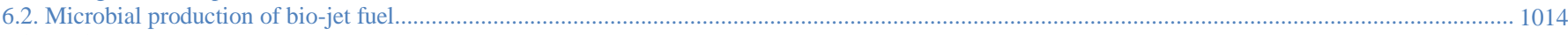

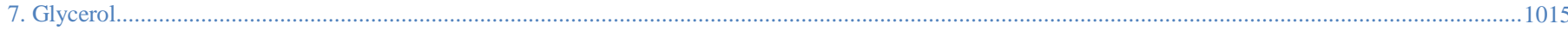

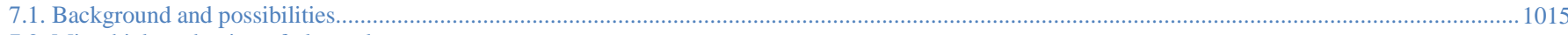

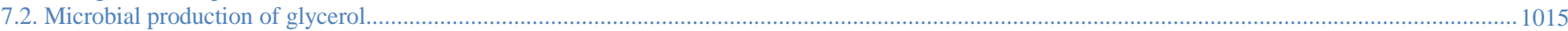

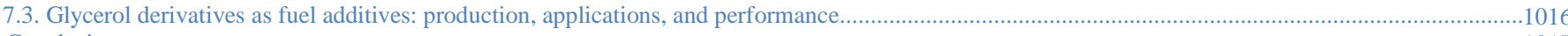

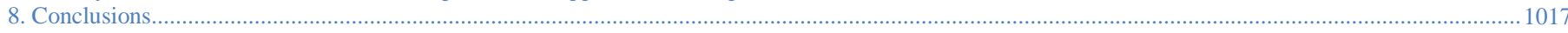

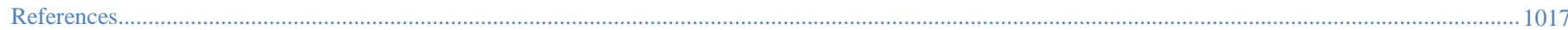

\begin{tabular}{|c|c|c|c|}
\hline \multicolumn{4}{|l|}{ Abbreviations } \\
\hline 2BGMH & 2-Butanone-Glycerol and Methyl Hexonoate & DDEFC & Direct Dimethyl Ether Fuel Cell \\
\hline $2 \mathrm{EH}$ & 2-Ethylhexyl & DEA & Diethanolamine \\
\hline $2 \mathrm{EHN}$ & 2-Ethylhexyl Nitrate & DEFC & Direct Ethanol Fuel Cell \\
\hline $2 \mathrm{M} 1 \mathrm{~B}$ & 2-Methyl-1-Butene & DEGEE & Diethylene Glycol Ethyl Ether \\
\hline 2M2B & 2-Methyl-2-Butene & DHAP & Dihydroxyacetone Phosphate \\
\hline AA & Acetic Acid & DEGME & Diethylene Glycol Monomethyl Ether \\
\hline $\mathrm{ABE}$ & Acetone-Butanol-Ethanol & DGME & Diethylene Glycol Methyl Ether \\
\hline $\mathrm{AD}$ & Anaerobic Digester & DMA & Dimethylamine \\
\hline AMO & NH3 Mono-Oxygenase & DMA-HCl & Dimethylamine Hydrochloride \\
\hline $\mathrm{AOB}$ & Ammonia-Oxidizing Bacteria & DMAPA & Dimethylaminopropylamine \\
\hline ASTM & American Society for Testing and Materials & DMC & Direct Microbial Conversion \\
\hline ATAEA & Activities of Total Amount of Enzyme Added & DME & Dimethyl Ether \\
\hline AtJ & Alcohol-to-Jet & DMFC & Direct Methanol Fuel Cell \\
\hline ATR & Autothermal Reforming & DMM & Dimethoxymethane \\
\hline B. subtilis & Bacillus subtilis & DMNA & Dimethylnitrosamine \\
\hline BGE & Butyl Glycerol Ether & DSHC & Direct Sugar to Hydrocarbon \\
\hline BGL-IU & $\beta$-glucosidase-International Unit Activity & E85 & A Mixture of $85 \%$ Ethanol and $15 \%$ Gasoline \\
\hline C. glycerinogenes & Candida glycerinogenes & E85 & by Volume \\
\hline CBP & Consolidated Bioprocessing & E. coli & Escherichia coli \\
\hline $\mathrm{CF} / \mathrm{S}$ & Chemical Formula/Symbol & ED & Entner-Doudoroff \\
\hline C. acetobutylicum & Clostridium acetobutylicum & EGBE & Monoethylene Glycol Butyl Ether \\
\hline C. beijerinckii & Clostridium beijerinckii & EGEE & Monoethylene Glycol Ethyl Ether \\
\hline $\mathrm{CN}$ & Chemical Name & ETBE & Ethyl Tert-Butyl Ether \\
\hline DBE & Dibutyl Ether & FAGE & Fatty Acid Formal Glycerol Ester \\
\hline DBG & Dibutoxy Glycerol & FABE & Fatty Acid Butyl Ester \\
\hline
\end{tabular}

Please cite this article as: Kazemi Shariat Panahi H., Dehhaghi M., Kinder J.E., Ezeji T.C. A review on green liquid fuels for the transportation sector: a prospect of microbial solutions to climate change. Biofuel Research Journal 23 (2019) 995-1024. DOI: 10.18331/BRJ2019.6.3.2 


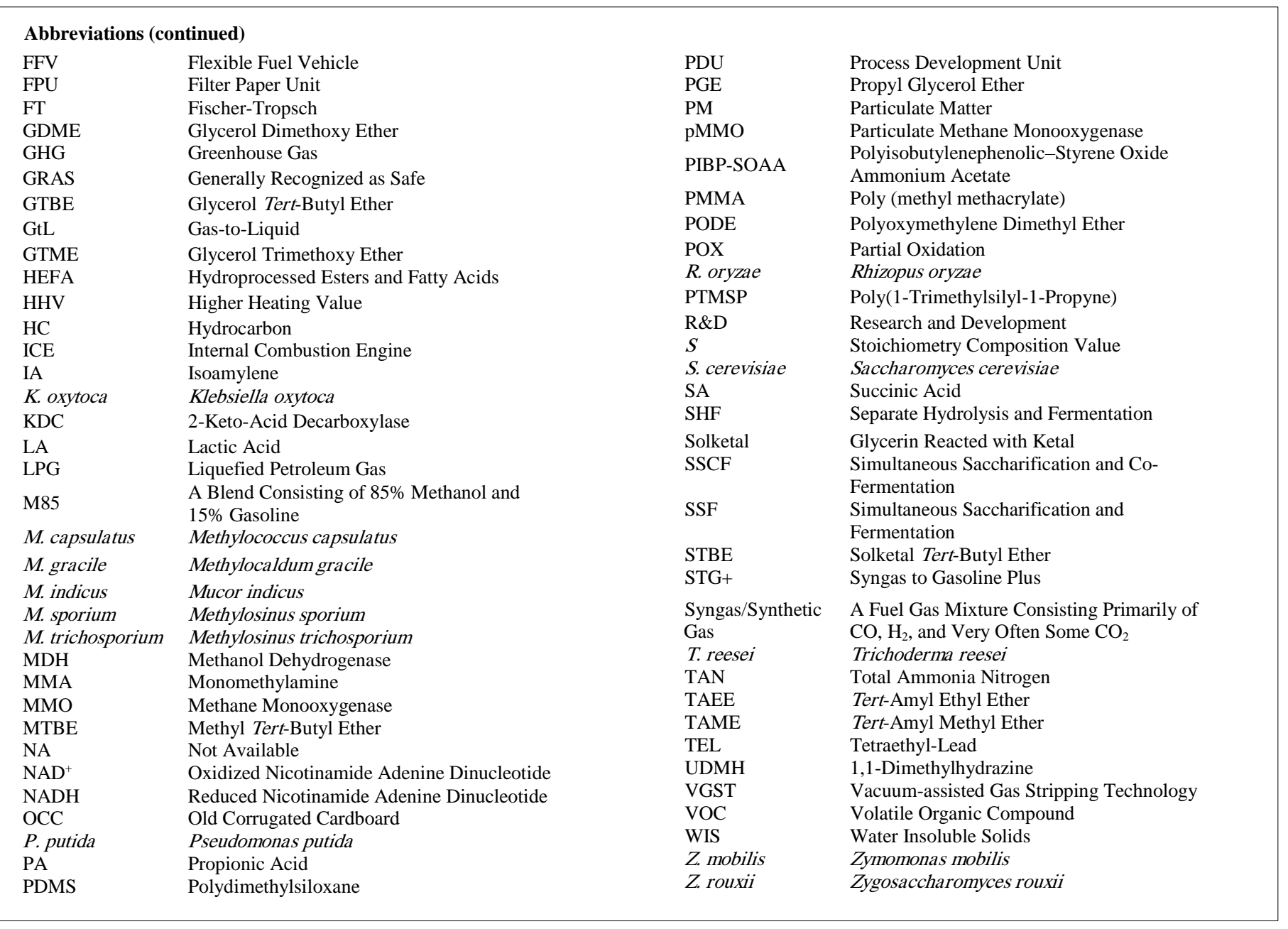

List of chemical formulas and symbols with their chemical names

\begin{tabular}{|c|c|c|c|c|c|}
\hline $\mathbf{C F} / \mathbf{S}^{\mathbf{a}}$ & $\mathbf{C N}^{\mathbf{b}}$ & CF/S & $\mathbf{C N}$ & CF/S & $\mathbf{C N}$ \\
\hline $\mathrm{Al}$ & Aluminum & $\mathrm{FeCl}_{3}$ & Ferric Chloride & $\mathrm{NaOH}$ & Sodium Hydroxide \\
\hline $\mathrm{Al}_{2} \mathrm{O}_{5} \mathrm{Si}$ & Aluminosilicate & $\mathrm{H}_{2}$ & Hydrogen Gas & $\mathrm{NaNO}_{3}$ & Sodium Nitrate \\
\hline $\mathrm{CHO}$ & Formyl Group & $\mathrm{HCl}$ & Hydrochloric Acid & $\mathrm{NH}_{2} \mathrm{Cl}$ & Chloramine \\
\hline $\mathrm{CH}_{3} \mathrm{ONa}$ & Sodium Methoxide & $\mathrm{H}_{3} \mathrm{PO}_{4}$ & Phosphoric Acid & $\mathrm{NH}_{4} \mathrm{NO}_{3}$ & Ammonium Nitrate \\
\hline $\mathrm{CH}_{4}$ & Methane & $\mathrm{H}_{2} \mathrm{~S}$ & Hydrogen Sulfide & $\mathrm{Ni}$ & Nickel \\
\hline $\mathrm{CO}$ & Carbon Monoxide & $\mathrm{H}_{2} \mathrm{SO}_{4}$ & Sulfuric Acid & $\mathrm{O}_{2}$ & Oxygen Gas \\
\hline $\mathrm{C}_{2} \mathrm{H}_{4}$ & Ethylene & $\mathrm{KOH}$ & Potassium Hydroxide & $\mathrm{O}_{3}$ & Ozone \\
\hline $\mathrm{C}_{3} \mathrm{H}_{3} \mathrm{~N}$ & Acrylonitrile & $\mathrm{K}_{2} \mathrm{PO}_{4}$ & Dipotassium Hydrogen Phosphate & $\mathrm{Pd}$ & Palladium \\
\hline $\mathrm{C}_{3} \mathrm{H}_{6}$ & Propylene & $\mathrm{K}_{2} \mathrm{SO}_{4}$ & Potassium Sulfate & $\mathrm{Pt}$ & Platinum \\
\hline $\mathrm{C}_{4} \mathrm{H}_{8}$ & Isobutene & $\mathrm{Mg}$ & Magnesium & $\mathrm{PtO}_{2}$ & Platinum Oxide \\
\hline $\mathrm{C}_{4} \mathrm{H}_{10}$ & Butane & $\mathrm{Mn}$ & Manganese & $\mathrm{Rh}$ & Rhodium \\
\hline $\mathrm{C}_{5} \mathrm{H}_{12}$ & Pentane & $\mathrm{NH}_{2} \mathrm{OH}$ & Hydroxylamine & $\mathrm{Ru}$ & Ruthenium \\
\hline $\mathrm{C}_{6} \mathrm{H}_{5} \mathrm{Cl}$ & Chlorobenzene & $\mathrm{NH}_{3}$ & Ammonia & $\mathrm{S}$ & Sulfur \\
\hline $\mathrm{C}_{15} \mathrm{H}_{24}$ & Farnesene & $\mathrm{NH}_{4}{ }^{+}$ & Ammonium Ion & $\mathrm{SO}_{\mathrm{X}}$ & Sulfur Oxides \\
\hline $\mathrm{C}_{15} \mathrm{H}_{32}$ & Farnesane & $\mathrm{NO}_{2}^{-}$ & Nitrite Ion & $\mathrm{SO}_{2}$ & Sulfur Dioxide \\
\hline $\mathrm{Cl}$ & Chlorine & $\mathrm{NO}_{X}$ & Nitrogen Oxides & $\mathrm{SO}_{4}^{2-}$ & Sulfate Ion \\
\hline $\mathrm{Co}$ & Cobalt & $\mathrm{N}_{2}$ & Nitrogen Gas & $\mathrm{Ti}(\mathrm{OBu}) 4 / \mathrm{AlEt}_{3}$ & Titanium Butoxide/Triethylaluminium \\
\hline $\mathrm{CuSO}_{4}$ & Copper Sulfate & $\mathrm{N}_{2} \mathrm{O}$ & Nitrous Oxide & $\mathrm{Zn}$ & Zinc \\
\hline $\mathrm{Cu}-\mathrm{ZnO}$ & Copper-Zinc Oxide & $\mathrm{NaCl}$ & Sodium Chloride & & \\
\hline
\end{tabular}




\section{Introduction}

Mortality from air pollution is greater than that from AIDS/HIV, tuberculosis, and road accidents combined. Indeed, as many as 6.5 million deaths occur annually worldwide from air pollution related illnesses, of which 3 million deaths are attributable to outdoor pollution, and number of deaths due to this pollution is expected to be 4.5 million by 2040 (Lancet, 2016; Kazemi Shariat Panahi et al., 2019a). For example, an estimated 50,000 people die annually from air pollution related diseases in Britain (Vidal, 2015). A recent estimate released by experts of the World Bank indicates that premature deaths associated with air pollution, fine particulate matter (PM) and ozone $\left(\mathrm{O}_{3}\right)$, account for US\$ 225 billion and US\$ 5.11 trillion in loss of income and reduced personnel welfare, respectively, thus, reducing productivity in the workforce (World Bank, 2016; Kazemi Shariat Panahi et al., 2019a). These loses are greater than the gross domestic products of many industrialized countries, including Canada and India (World Bank and Institute for Health Metrics and Evaluation, 2016). The cost of losses due to compromised environmental quality could be greater if a wider range of pollutants and associated effects on health were considered (Amini and Sowlat, 2014).

Emissions from industrial facilities, power plants, and transportation vehicles are major source of outdoor pollution. Because air pollution cannot be constrained by borders, implementation of effective mitigation strategies requires coordinated efforts across organizations and nations (Kazemi Shariat Panahi et al., 2019a). For example, scientists and politicians of different nationalities urged the leadership of all countries to have a unified approach in addressing global air pollution problems and detrimental effects for animal and plant habitation on the earth during the Paris climate summit (Kazemi Shariat Panahi et al., 2019a). Although emissions can be reduced through the use of post-combustion control techniques, the generation of forms of energy that do not result in high levels of pollution provides for a more sustainable and effective solution to pollution problems (Aghbashlo et al., 2018; Rahimzadeh et al., 2018).

On the other hand, population growth and lifestyle changes result in greater pollution with development and growth of cities and the resulting energy use in concentrated physical locations. For example, $85 \%$ of air pollution generated in 2013 in Tehran, Iran, a city of 8.2-million residents, came from transportation vehicles, whereas emissions from industries, energy conversion, households, and terminals accounted for the remaining portion (Shahbazi et al., 2016). The pollutants include carbon monoxide (CO), nitrogen oxides $\left(\mathrm{NO}_{\mathrm{X}}\right)$, $\mathrm{PM}$, sulfur oxides $\left(\mathrm{SO}_{\mathrm{x}}\right)$, methane $\left(\mathrm{CH}_{4}\right)$, and volatile organic compounds (VOCs). The mobile nature of air pollutants poses even greater risks to people in developing countries than those living in the developed world, given the high mortality rate in these countries typically caused by poverty as well as poor infrastructure and medical care. In addition to health problems, these pollutants contribute to a global warming effect (Kazemi Shariat Panahi et al., 2019c). Indeed, pollution due to transportation resulted in generation of $7.0 \mathrm{GtCO}_{2} \mathrm{eq}$ of direct greenhouse gas (GHG) emissions (non- $\mathrm{CO}_{2}$ gases included) in 2010, hence is responsible for approximately $23 \%$ of total energy-related $\mathrm{CO}_{2}$ emissions (United Nations, 2015). Accordingly, the calculated values for GHGs emissions over a 40-year period indicate a 2.5-fold increase from 1970 to 2010 , with the emission from the road transportation sector accounting for almost three quarters of these emissions.

While electricity generation from natural resources such as solar, wave, and wind (which will result in less air pollution) has the potential to replace the energy from coal-burning power plants, the technology for retrofitting the physical infrastructure of the transportation sector to use such renewable energy carriers has not been developed yet, is inefficient, and/or expensive. Consequently, the current number of 1.2 billion vehicles on roads worldwide continue to result in a huge reliance on fossil fuels for operation if cogent progress is not made in the area of alternative non-fossil based production of fuels (Kazemi Shariat Panahi et al., 2019c). On the other hand, there are estimates that the total number of road vehicles worldwide will increase to 2 billion by 2035 (Voelcker, 2015). If the environmental and health effects of air pollution as a result of GHGs emission are not addressed through a cohesive strategic plan which includes gradual replacement of fossil-fuels with liquid biofuels (such as butanol, ethanol, methanol, biokerosene, etc.), the detrimental effects of fossil-based fuels emissions will continue to contribute to environmental demise. In addition to pollution concerns, energy sources such as crude oil and gas that are the main feedstock for the production of different fuels and chemicals are not renewable. This concern has been expressed by scientists, as well as leaders of many countries, who have long-term energy strategic plans.

Microorganisms are potent producers of various value-added bioproducts through assimilation of cheap residues and wastes (Hamedi et al., 2015b; Mohammadipanah et al., 2015). At present, the application of microbial-based technologies has significantly contributed to solving various problems encountered by humans, ranging from antibiotic and enzyme production to bioremediation and even disease prevention (Hamedi et al., 2015a; Mohammadipanah et al., 2016; Panahi et al., 2016; Dehhaghi and Mohammadipanah, 2017; Dehhaghi et al., 2018a and b; Sajedi et al., 2018; Dehhaghi et al., 2019). In line with this, the present review comprehensive presents and discusses chemicals with promising liquid fuel properties produced using fermentation of biomass by bacteria and yeasts. The focus is on production, fuel properties, and derivatization of chemicals with biotechnological significance. Factors are also identified that impede commercial fermentative production of chemicals, and approaches are recommended to address feasibility challenges for bio-production of these compounds. For reference purposes, gasoline properties (Table 1) will serve as the standard for comparing biofuels that are addressed in this review.

Table 1.

Fuel properties of gasoline.

\begin{tabular}{ll}
\hline Chemical formula & Hydrocarbons with 4 to 12 carbon atoms \\
Boiling point $\left({ }^{\circ} \mathrm{C}\right)$ & $100-400$ \\
Composition, weight \% C & $85-88$ \\
Density $\left(\mathrm{kg} / \mathrm{m}^{3}\right)$ & $719-760$ \\
Ignition temperature $\left({ }^{\circ} \mathrm{C}\right)$ & $247-280$ \\
Thermal expansion coefficient $\left(\mathrm{K}^{-1}\right)$ & $900 \times 10^{-6}$ \\
Viscosity $\left(\mathrm{m}^{2} / \mathrm{s}\right)$ & $0.5 \times 10^{-6}$ \\
Flammability limits, vol \%, lower, higher & $1.4,7.6$ \\
Air-fuel ratio $(\mathrm{kg} / \mathrm{kg})$ & 14.7 \\
Heat of vaporization $(\mathrm{MJ} / \mathrm{kg})$ & 0.36 \\
Calorific value $(\mathrm{MJ} / \mathrm{kg})$ & 46.7 \\
Research octane No. & $90-98$ \\
Motor octane No. & $85-87$ \\
Cetane No. & $5-20$ \\
\hline
\end{tabular}

\section{Methanol}

\subsection{Development of methanol as fuel: attributes, challenges and mitigating strategies}

The use of alcohols (i.e., methanol or ethanol) as fuel has been considered an option since the time of development of the internal combustion engine (ICE) because some of the engines were designed to operate with alcohol as fuel with the aim of upgrading steam engines as the technology of engine design improved (Olah et al., 2011). Methanol has been the fuel of choice for Indianapolis-type racecars (Indianapolis, Indiana State, USA) since the 1960s due to its superior performance as well as safety attributes (Table 2). Methanol, however, lost favor as a major fuel mainly due to discovery of petroleum deposits from which energy could be derived that was more economical. Interest in the use of alcohols as fuel was rekindled during the 1973 oil crisis when the Organization of Arab Petroleum Exporting Countries (OAPEC) sanctioned some western countries for the support of Israel, which resulted in an increase in cost of petroleum-derived products. Consequently, a study was conducted in 1973 through which an engine was developed with very desirable gas mileages and relatively lesser pollution when a methanol-gasoline blend was used as an energy source (Reed and Lerner, 1973). Soon after, in 1975, Volkswagen conducted a field test with 45 vehicles where engines were slightly modified to operate with use of a $15 \%$ blend of methanol-gasoline (Hal et al., 1982). Interestingly, the use of methanol as an energy source resulted in a greater octane rating of the engine fuel and there was a greater 
Table 2.

Fuel properties of methanol.

Chemical formula

$\mathrm{CH}_{3} \mathrm{OH}$

Structure

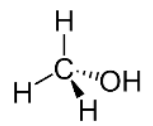

\begin{tabular}{ll} 
Molar mass $(\mathrm{g} / \mathrm{mol})$ & 32.04 \\
Boiling point $\left({ }^{\circ} \mathrm{C}\right)$ & 64.7 \\
Melting point $\left({ }^{\circ} \mathrm{C}\right)$ & -97.6 \\
Composition, weight $\% \mathrm{C}$ & 37.5 \\
Density $\left(\mathrm{kg} / \mathrm{m}^{3}\right)$ & 792 \\
Ignition temperature $\left({ }^{\circ} \mathrm{C}\right)$ & 470 \\
Flash point $\left({ }^{\circ} \mathrm{C}\right)$ & $11-12$ \\
Thermal expansion coefficient $\left(\mathrm{K}^{-1}\right)$ & 0.00149 \\
Viscosity $\left(\mathrm{m}^{2} / \mathrm{s}\right)$ & $7.37 \times 10^{-7}$ at $20^{\circ} \mathrm{C}$ \\
Flammability limits, vol.\%, lower, higher & $7.3,36$ \\
Calorific value $(\mathrm{MJ} / \mathrm{kg})$ & 22.7 \\
Air-fuel ratio $(\mathrm{kg} / \mathrm{kg})$ & 6.4 \\
Vapor pressure & $32 \mathrm{kPa}$ \\
Heat of vaporization $(\mathrm{MJ} / \mathrm{kg})$ & 1.2 \\
Research octane No. & 108.7 \\
Motor octane No. & 88.6 \\
Cetane No. & 5 \\
\hline
\end{tabular}

amount of engine power than with use of pure gasoline. Similarly, 84 vehicles were operated with pure methanol as fuel in a partnership involving Ford and Volkswagen Motor companies, and the engines of the vehicles had a greater efficiency and durability than the engines of gasoline-powered vehicles (Perry and Perry, 1990). There were efforts by the California State Government in promotion of M85 fuel, which is a blend consisting of $85 \%$ methanol and $15 \%$ gasoline (Olah et al., 2011), that resulted in the production of approximately 20,000 units of FFVs by 1997 (Energy Information Administration, 1988) which indicates the desirable fuel properties of methanol. The introduction of FFVs with the capacity to operate when any blend of alcohol with gasoline or alcohol alone was used, indicates that methanol is a credible liquid fuel (Olah et al., 2011).

Use of methanol as transportation liquid fuel has some challenges and shortfalls. Indeed, methanol has different physicochemical characteristics such as a relatively greater dipole moment and dielectric constant, and being miscible with water compared to gasoline. Furthermore, when methanol concentration exceeds $10 \%$ in gasoline-methanol blends, the fuel may be incompatible with some of the engine components such as the distributor, connector, as well as fuel storage and delivery system in gasoline-powered automobiles. Another shortfall with use of methanol is the corrosion of some metals such as aluminum ( $\mathrm{Al})$, magnesium $(\mathrm{Mg})$, and zinc $(\mathrm{Zn})$ components of automobiles (Bechtold, 1997) while the problematic reaction of methanol with some plastics, gaskets, rubbers, engine oil and greases must also be considered before use to avoid leaks or system malfunctions (Olah et al., 2011). To mitigate these limitations, methanol-resistant compounds such as steel and cast iron must be used for building components of systems that have direct contact with methanol. These modifications are assumed to be only a marginal limitation from use of methanol as these alterations do not significantly increase the overall production cost of the system (Olah et al., 2011). Meanwhile, there is "cold-start" problem associated with use of pure methanol as an energy source for engines. This problem can be mitigated with either addition of small amounts of highly volatile compounds (e.g., butane $\left[\mathrm{C}_{4} \mathrm{H}_{10}\right]$, isobutene $\left[\mathrm{C}_{4} \mathrm{H}_{8}\right]$, or pentane $\left[\mathrm{C}_{5} \mathrm{H}_{12}\right]$ ) (Cheng and Kung, 1994) or installation of a device that can atomize or vaporize methanol into easily-ignited minute droplets (Olah et al., 2011). It should be noted that "cold-start" problems have not been observed when M85 fuel is used in FFVs even in the coldest climates (Olah et al., 2011).

Interestingly, a tri-flex-fuel car (Exige 270E) with the capacity for use of mixtures of ethanol, gasoline and methanol was unveiled in 2006 by the Lotus Car Company (News Release Lotus Engineering, 2008). The company emphasized on the fuel properties of methanol and its suitability for ICEs in terms of performance, thermal efficiencies, and pressurecharging (News Release Lotus Engineering, 2008) as corroborated with combustion properties presented in Table 2. Compared to gasoline (Table 1), methanol has a greater research octane rating of about 109; allowing less compression of the air-to-fuel mixture before ignition by the sparkplug. The latent heat of vaporization of methanol allows the removal of generated heat from engines through possible application of air-cooled radiators instead of water-cooled systems. There are some highly positive attributes of optimized methanol-powered engines such as greater acceleration and mileage with use of smaller and lighter engine blocks that require lesser cooling, as compared to gasoline engines, while at the same time there is less overall air pollutant emissions such as hydrocarbons (HCs), particulates, $\mathrm{NO}_{\mathrm{x}}$, and sulfur dioxide $\left(\mathrm{SO}_{2}\right)$ (Nowell, 1994; Olah et al., 2011). These advantages compensate for the lesser energy density of methanol, which is about half of that of gasoline (Olah et al., 2011).

Methanol can be dehydrated to dimethyl ether (DME), which was first introduced as a diesel fuel during the 1990s. Methanol is commonly used for transesterification of oils and fats derived from vegetable matter, animal tissues, and microorganisms (Tabatabaei et al., 2019a) (see Section 7), and it is an excellent carrier for hydrogen $\left(\mathrm{H}_{2}\right)$ fuel as each liter of methanol at ambient temperatures contains approximately $99 \mathrm{~g}$ of $\mathrm{H}_{2}$, compared to $71 \mathrm{~g}$ with liquid $\mathrm{H}_{2}$ at $-253{ }^{\circ} \mathrm{C}$ (Olah et al., 2011). The absence of C-C bonds, which are not easily broken, significantly facilitates in situ steam transformation of methanol at 250 to $350{ }^{\circ} \mathrm{C}$ to high purity $(80-90 \%$ efficiency) $\mathrm{H}_{2}$, with no $\mathrm{NO}_{\mathrm{x}}$ generation (Romm, 2004; Olah et al., 2011). In addition to transportation and other mobile applications, methanol can be used for static applications such as electricity and heat generation. In this regard, using methanol as an energy source can occur in gas turbines of transport vehicles more efficiently than natural gas or light petroleum distillate fractions while there is less generation of $\mathrm{NO}_{\mathrm{x}}$ and zero $\mathrm{SO}_{2}$ emissions (Temchin, 2003; Olah et al., 2011). It is also easier to use and safer to transport than natural gas

When there is a fire and/or explosion, methanol gas concentration in air must be four times greater than that of gasoline for ignition to occur, whereas its rapidity of burning is almost four times less while there is a release of one-eighth the heat, compared to gasoline (Olah et al., 2011). The methanol has a lesser radiant heat output and, therefore, a fire is less likely to spread to nearby flammable materials than is the situation with gasoline fuel. The relative risk of flammability with use of gasoline- and methanolpowered cars was tested and it was revealed that with gasoline-powered cars, ignition of the fuel was more rapid and entirely within minutes when the leaked fuel was subjected to an open flame. In contrast, with methanol there was no flammability for a three-fold longer time and the fire was restricted to only the rear of the car (Cheng and Kung, 1994). Based on this study, the Environmental Protection Agency concluded that substitution of gasoline with methanol would decrease the fuel-related fire incidents by 90\%. Additionally, methanol burns more cleanly, reducing the risks of smoke inhalation associated injuries, and more clearly, resulting in a ligh blue flame that is visible in most situations and is easily distinguishable.

\subsection{Chemical synthesis of methanol}

While there are various potential techniques to produce methanol, almost all methanol that is currently marketed is exclusively produced from carbon oxides $\left(\mathrm{CO}\right.$ and $\left.\mathrm{CO}_{2}\right)$ and $\mathrm{H}_{2}$ in an ideal stoichiometry composition value $(S)$ of about two (Eq. 1) through use of a syngas production process. These gases, known as syngas or synthesis gas, are derived from $\mathrm{CH}_{4}$ sourced through natural gas, coal, petroleum resources, and biogas. These processes may be conducted at different temperatures and pressures such as: (i) 800 to $1000{ }^{\circ} \mathrm{C}, 2$ or $3 \mathrm{MPa}$ with a nickel (Ni) based catalyst addition for steam reforming; (ii) 800 to $1500{ }^{\circ} \mathrm{C}, 0.5$ to $4 \mathrm{MPa}$ with/without a catalyst for partial oxidation (POX); and (iii) a process developed by Johnson Matthey (formerly ICI Synetix) which operates at 200 to $300{ }^{\circ} \mathrm{C}, 5$ to $10 \mathrm{MPa}$ with addition of a copper-zinc oxide- $(\mathrm{Cu}-\mathrm{ZnO})$ based catalyst (Kochloefl, 1997; 
Fiedler et al., 2003; Choudhary and Choudhary, 2008). Using these processes, a $99.8 \%$ methanol selectivity and energy efficiency as high as $75 \%$ may be obtained (Olah et al., 2011). Currently, the most commonly used feedstock for the production of methanol is natural gas, for example, mega-methanol plants in Iran produce methanol at USD100/t. It should be noted that transformation of other feedstocks such as coal, petroleum oil, and long-chain HCs to methanol is relatively expensive as generation and purification costs to remove impurities such as sulfur that destroys catalyst systems from the intermediate product, i.e., syngas, increase the cost of production. Indeed, syngas generation generally accounts for as much as $70 \%$ to $80 \%$ of the total investment for syngas-based methanol-producing plants, depending on the type of feedstock (Hansen, 1997).

$S=\frac{\left(\text { moles } \mathrm{H}_{2}-\text { moles } \mathrm{CO}_{2}\right)}{\left(\text { moles } \mathrm{CO}+\text { moles } \mathrm{CO}_{2}\right)}$

\subsection{Biological production of methanol: significance of $\mathrm{CH}_{4}$ in methanol- producing microorganisms}

Two groups of bacteria, methanotrophic and ammonia-oxidizing bacteria (AOB), can convert $\mathrm{CH}_{4}$ to methanol in aerobic conditions (Hanson and Hanson, 1996; Taher and Chandran, 2013). Methanotrophic bacteria can function to activate and oxidize the stable $\mathrm{C}-\mathrm{H}$ bond of $\mathrm{CH}_{4}$ as a result of the action of the $\mathrm{CH}_{4}$ monooxygenase (MMO) enzyme, thus, facilitating the use of $\mathrm{CH}_{4}$ as a carbon (C) source. In the AOB, there can be use of ammonia $\left(\mathrm{NH}_{3}\right)$ as the nitrogen $(\mathrm{N})$ source in a process that results in partial oxidation of $\mathrm{CH}_{4}$ to methanol. Additionally, some methanotrophic bacteria and archaea have the capacity to produce methanol through anaerobic oxidation of $\mathrm{CH}_{4}$ coupled with the reduction of nitrite $\left(\mathrm{NO}_{2}{ }^{-}\right)$and sulfate ions $\left(\mathrm{SO}_{4}{ }^{2-}\right)$, as well as manganese $(\mathrm{Mn})$, or iron $(\mathrm{Fe})$ in the growth medium (Boetius et al., 2000; Beal et al., 2009; Ettwig et al., 2010; Ge et al., 2014). Notably, no anaerobic methanotrophs have been isolated either in a consortium or in a pure culture (Haynes and Gonzalez, 2014). Aerobic methanotrophic bacteria are classified in two classes of Proteobacteria, i.e., $\alpha$-Proteobacteria and $\gamma$-Proteobacteria. These two classes of Proteobacteria comprise 16 genera that include Clonothrix, Crenothrix, Methylobacter, Methylocaldum, Methylocapsa, Methylocella, Methylococcus, Methylocystis, Methylohalobius, Methylomicrobium, Methylomonas, Methylosarcina, Methylosinus, Methylosoma, Methylosphaera, and Methylothermus (Semrau et al., 2010; Ge et al., 2014). Methanotrophs can also be categorized into two groups, i.e., facultative and obligate. For facultative methanotrophs, the primary $\mathrm{C}$ or energy source is generally $\mathrm{C} 1$ substrates of which $\mathrm{CH}_{4}$ is the most common substrate type, whereas obligate methanotrophs assimilate $\mathrm{C} 1$ as well as multi-C substrates (Theisen and Murrell, 2005). For example, Methylocapsa aurea, Methylocella sp., and Methylocyctis sp. are facultative methanotrophs (Dedysh et al., 2005; Dunfield et al., 2010). It should be noted that the most precisely characterized methanotrophic strains are obligate methanotrophs with the exception of Methylocella silvestris BL2, which is a facultative methanotroph (Ge et al., 2014). The identified AOB are classified into five genera of Nitrosomonas, Nitrosococcus, Nitrosolobus, Nitrosospira, and Nitrosovibrio. All these genera belong to the class $\beta$ Proteobacteria, except Nitrosococcus that are of the $\gamma$-Proteobacteria class. These bacteria co-oxidize $\mathrm{CH}_{4}$ and $\mathrm{NH}_{3}$ with catalytic action of $\mathrm{NH}_{3}$ monooxygenase (AMO) during a two-step process that oxidizes $\mathrm{NH}_{3}$ to $\mathrm{NO}_{2}{ }^{-}$or to hydroxylamine $\left(\mathrm{NH}_{2} \mathrm{OH}\right)$; subsequently, hydroxylamine is oxidized to $\mathrm{NO}_{2}^{-}$by $\mathrm{NH}_{2} \mathrm{OH}$ oxidoreductase. Compared to methanotrophs, the efficiency of bioconversion of $\mathrm{CH}_{4}$ to methanol by AOB is less. Furthermore, a major disadvantage of AOB is the capacity to produce nitrous oxide $\left(\mathrm{N}_{2} \mathrm{O}\right)$, one of the four main GHGs with the greatest contamination capacity as it has more than 300 times the GHG effect of $\mathrm{CO}_{2}$ (Stein and Yung, 2003).

The $\mathrm{CH}_{4}$ compound is the major component of natural gas (up to $98 \%$ ) with 194 trillion $\mathrm{m}^{3}$ of global reserves reported to exist in 2012 (Ge et al., 2014). Microbial conversion of $\mathrm{CH}_{4}$ to methanol is an environmentally compatible processing option for conversion of gas into liquid fuel. Additionally, $\mathrm{CH}_{4}$ constitutes the major component of biogas $(60 \%-70 \%$, v/v) produced using anaerobic digestion of organic wastes (Jingura and Kamusoko, 2017; Shirzad et al., 2019; Tabatabaei et al., 2019b). Although $\mathbf{C H}_{4}$ is a high quality fuel source, it is difficult to store and transport, and there is often requirements for considerable energy inputs and large capital expenditures for its transport to the final consumer. Furthermore, emission of $\mathrm{CH}_{4}$ to the atmosphere is hazardous as it is believed to account for $17 \%$ of the global warming effect of emissions (Stocker et al., 2013). To address these issues, $\mathrm{CH}_{4}$ can be efficiently converted into a fuel (such as methanol) that is environmentally compatible with use of chemical and microbial processes. Use of biogas (i.e., $\mathrm{CH}_{4}$ ), instead of natural gas, as a feedstock for biological production of methanol is receiving considerable attention because the process allows the conversion of decomposing organic wastes into valuable products and facilitates the attainment of long-term energy sustainability (Ge et al., 2014). Furthermore, the biological $\mathrm{CH}_{4}$ to methanol conversion process can be implemented for use of impure $\mathrm{CH}_{4}$ as a feedstock, unlike the chemical process where pure $\mathrm{CH}_{4}$ is required without having impurities such as hydrogen sulfide $\left(\mathrm{H}_{2} \mathrm{~S}\right), \mathrm{NH}_{3}$, and siloxane. With the chemical process, there needs to be economically costly inactivation of these impurities through use of metal catalysts that facilitate the use of this conversion process.

For example, biogas may contain as much as $1000 \mathrm{ppm} \mathrm{H}_{2} \mathrm{~S}$ depending on the abundance of $\mathrm{SO}_{4}{ }^{2-}$-reducing bacteria that reduce $\mathrm{SO}_{4}{ }^{2-}$ to $\mathrm{H}_{2} \mathrm{~S}$ in the anaerobic digester. Notably, $\mathrm{H}_{2} \mathrm{~S}$ and $\mathrm{NH}_{3}$ can inhibit the growth of methanotrophs (such as Methylosinus trichosporium OB3b) if concentration of these compounds in the bioreactor exceed optimal threshold (typically 0.13 and $0.05 \%$, respectively) (Ge et al., 2014). Some pure and mixed cultures of methanotrophic bacteria are capable of metabolizing crude biogas. Indeed in the presence of crude biogas, there is an increase in density and optimal growth rate in cultures of Methylocystus parvus OBBP, Methylocaldum sp. 14B, and Methylocaldum gracile SAD2; and two methanotrophic consortia, (i) a consortium of Methylosinus sporium NCIMB 11126, M. trichosporium OB3b and Methylococcus capsulatus, and (ii) a thermotolerant methanotrophic consortium otherwise known as MC-AD3 (Criddle et al., 2012; Han et al., 2013; Sheets et al. 2016; Zhang et al., 2016; Su et al., 2017). The capacity of these bacteria to metabolize $\mathrm{CH}_{4}$ in crude biogas is noteworthy because the cost of $\mathrm{H}_{2} \mathrm{~S}$ removal from biogas may be as high as USD $0.38 / \mathrm{m}^{3} \mathrm{CH}_{4}$. Some aerobic methanotrophs can oxidize $\mathrm{H}_{2} \mathrm{~S}$ in biogas when these microbes are exposed to small amounts of air in an anaerobic digestion system (Ge et al., 2014). The biogas can also be purified using $\mathrm{NH}_{3}$ stripping processes to separate $\mathrm{NH}_{3}$ (Walker et al., 2011). Nevertheless, $\mathrm{H}_{2} \mathrm{~S}$ - and/or $\mathrm{NH}_{3}$-tolerant methanotrophs such as M. gracile SAD2, Methylomicrobium album, and Methylocystis sp. have also been isolated (Cáceres et al., 2014; Zhang et al., 2016).

Overall, $M$. trichosporium is the most studied of the methanotrophic microbes for methanol biosynthesis. M. trichosporium has high specific activities of soluble methane monooxygenase of $85 \mathrm{nmol} / \mathrm{min} / \mathrm{mg}$ protein [reductant, $5 \mathrm{mM}$ reduced nicotinamide adenine dinucleotide (NADH); substrate, $\mathrm{CH}_{4}$; and absence of $\mathrm{Cu}$ and $93.5 \mathrm{nmol} / \mathrm{min} / \mathrm{mg}$ protein [(reductant, $1 \mathrm{mM}$ duroquinol; substrate, propylene $\left.\left(\mathrm{C}_{3} \mathrm{H}_{6}\right)\right]$, and particulate methane monooxygenase [(pMMO) activity of $13.3 \mathrm{~mol} / \mathrm{mol} \mathrm{Cu} / \mathrm{protein})]$ (Colby et al., 1977; Chan et al., 2011). Notably, the presence of $\mathrm{Cu}^{2+}(10$ $\mu \mathrm{M}$ ) improves specific growth rate of $M$. trichosporium OB3b (Park et al. 1992), and the use of paraffin oil (5\% v/v) as substrate results in a greater growth rate and cell density of methanotrophs because it increases mass transfer of $\mathrm{CH}_{4}$ between the gas and aqueous phases (Han et al., 2009). Beyond pure cultures of methanotrophs, mixed cultures have also been studied (Han et al., 2013). Two of the most important mixed cultures ever studied are a three-bacterial-association of $M$. sporium NCIMB 11126, $M$. trichosporium OB3b, and $M$. capsulatus, and the thermotolerant methanotrophic consortium, i.e., MC-AD3 (Han et al., 2013; Su et al., 2017).

Because MMO is a very important enzyme for function of these microorganisms in the catalysis of $\mathrm{CH}_{4}$ to methanol, cloning and expression of the gene for this enzyme in Escherichia coli and the subsequent use of the generated recombinant $E$. coli or enzyme in methanol biosynthesis seems to be an attractive opportunity. The cofactor requirements for MMO catalysis and problems associated with MMO instability, however, make the utilization of pure MMO difficult, an impediment that does not exist when methanotrophs (i.e., whole cells) are used. Nonetheless, methanotrophs often oxidize methanol to $\mathrm{CO}_{2}$ through transfer of an electron from methanol to cytochrome $\mathrm{C}_{\mathrm{L}}$ (Anthony, 1992). Methanol dehydrogenase $(\mathrm{MDH})$, a pyrroloquinoline-containing enzyme, is the enzyme responsible for the catalytic oxidation of methanol to $\mathrm{CO}_{2}$. By distorting the active site of $\mathrm{MDH}$ and adding formate to the medium to serve as an electron donor for maintenance of cell viability (Ge et al., 2014), oxidation of methanol to $\mathrm{CO}_{2}$ may be prevented and thus, facilitating the accumulation of methanol in the bioreactor. However, one of the main 
constraints on the way of commercial exploitation of this approach is that application of formate for this purpose renders the industrial production of methanol not economically feasible. Therefore, there is the need to develop alternative approaches that are less economically costly to meet the electron donor requirement for methanol production (Ge et al., 2014). On this basis, the use of facultative aerobic methanotrophs for the production of methanol have been suggested because these microbes have the capacity to utilize mono- or multi-C compounds such as acetate and other volatile fatty acids as the energy source for growth and methanol production (Dedysh and Dunfield, 2011). Alternatively, electrotrophic methanotrophs, which have the capacity to accept electrons from electrodes, could be investigated as useful microbes for methanol production. Indeed, formate could be produced through electrochemical $\mathrm{CO}_{2}$ reduction coupled with $\mathrm{H}_{2} \mathrm{O}$ oxidation utilizing tungstencontaining formate dehydrogenase (Reda et al., 2008). The generation of formate by microbial electrosynthesis is an economically viable prospect for formate production (Ge et al., 2014).

Likewise, supplementation of the growth medium with ethylenediaminetetraacetic acid or ethylene glycol tetraacetic acid (EGTA) is a plausible strategy for chelating the $\mathrm{Ca}^{2+}$ in the $\mathrm{MDH}$ structure and detorting its active site. In fact, the conformation of the active site of MDH is maintained by $\mathrm{Ca}^{2+}$ (Zheng and Bruice, 1997). Interestingly, relatively greater titers of monovalent cations $(50-200 \mathrm{mM})$ such as dipotassium hydrogen phosphate $\left(\mathrm{K}_{2} \mathrm{PO}_{4}\right)$, potassium sulfate $\left(\mathrm{K}_{2} \mathrm{SO}_{4}\right)$, and sodium chloride $(\mathrm{NaCl})$ have been reported to be potent reducers of the activity of $\mathrm{MDH}$ and obstruction of methanol oxidation (Cox et al., 1992). Additionally, cyclopropanol in amounts as small as $3 \mu \mathrm{M}$ (Takeguchi et al., 1997) inhibit the activity of MDH by as much as $50 \%$ through interaction with pyrroloquinoline quinone (free or bonded). Cyclopropanol undergoes an irreversible reaction with $\mathrm{MDH}$ to form a stable C5 3-propanal adduct of pyrroloquinoline quinone (Frank et al., 1989). The greatest disadvantage of using cyclopropanol for the inhibition of MDH, however, is the susceptibility of the compound to oxygen- $\left(\mathrm{O}_{2}\right)$ and instability in aerobic conditions (Han et al., 2013). Nevertheless, significant progress on microbial conversion of biogas to methanol is needed to produce methanol at titers that justify industrial scale production. There has been no commercial microbial-based methanol plants constructed or operational because of the impediments described above, thus, emphasizing the need for an enhanced research focus on these realms.

\subsection{Methanol derivatives as fuel components: production, application, and performance}

Methanol is a feedstock alcohol that can easily be converted into other fuels and fuel additives (Fig. 1). Direct conversion of methanol into ethanol can occur using a two-step process. The first step involves reductive carbonylation of methanol to acetaldehyde in the presence of rhodium- (Rh) based catalysts. In the second step, acetaldehyde is reduced to ethanol with the incorporation of ruthenium $(\mathrm{Ru})$ as a co-catalyst.

Some commercial gasoline detergents that improve vehicle fuel economy by functioning as cleaning agents of intake valves, can also be produced using methanol as the major feedstock (Fig. 1). For example, the styrene oxide which is used in polyisobutylenephenolic-styrene oxide ammonium acetate (PIBPSOAA) production can be prepared by reacting methanol-derived formaldehyde with toluene to form styrene in separate reactors followed by epoxidation of styrene with peroxybenzoic acid in the Prilezhaev reaction (Butler and Pelati, 2010; DeRosa, 2012). The DME compound can be derived by dehydration of methanol utilizing a mildly acidic catalyst with no need for isobutylene inclusion. The DME compound is an eco-friendly chemical, noncorrosive, non-carcinogenic, and non-toxic, which is superior and contains greater amounts of calorific fuel than methanol, and can be used to operate diesel engines. Similar to liquefied petroleum gas (LPG), DME is generally stored in liquid state in pressurized tanks. The exhaust gas from DME burning contains no black smoke, soot, or $\mathrm{SO}_{2}$ and there is only the release of very small amounts of $\mathrm{NO}_{\mathrm{x}}$ and other emissions (Olah et al., 2011). Additionally, DME can be used as a fuel additive for gasoline or diesel fuel.

Methyl tert-butyl ethers (MTBE) have been produced at a commercial scale since the 1970s for fuel industry application. In the 1980s, MTBE was increasingly utilized as an octane booster and an "antiknock" additive for gasoline following the phasing out of the use of toxic and harmful tetraethyllead (TEL) (Kazemi Shariat Panahi et al., 2019a). The TEL compound was obtained by processing ethyl chloride, a compound derived from ethanol after

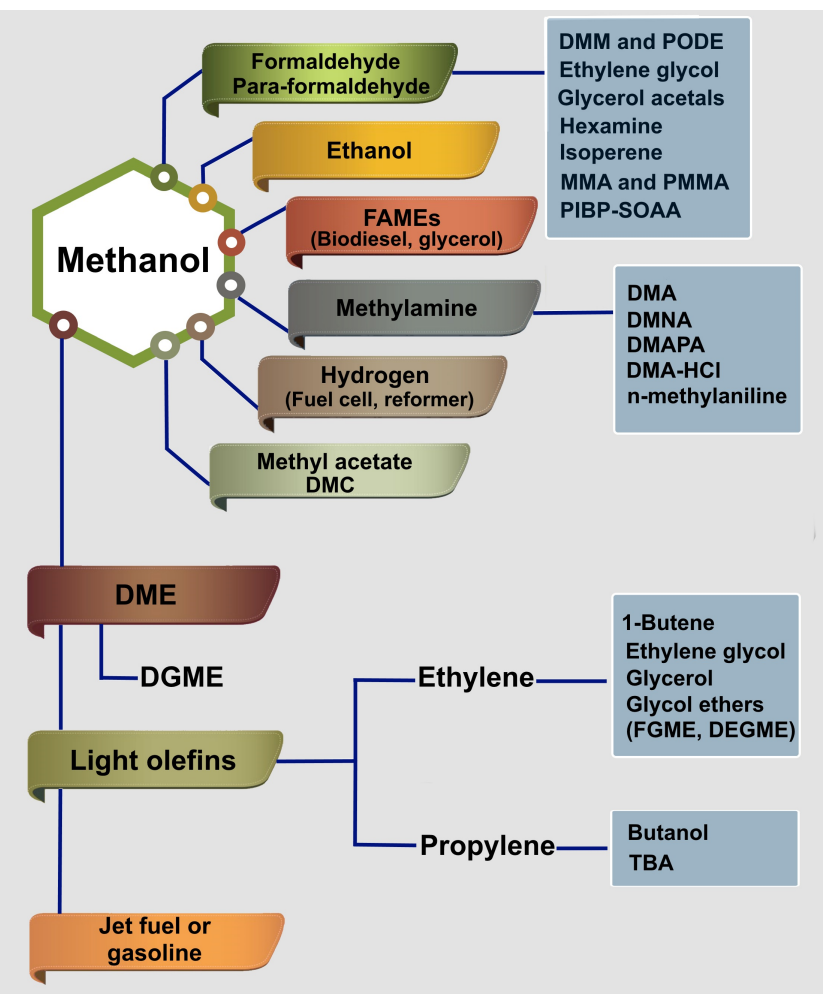

Fig. 1. Methanol-derived compounds for potential use as fuel, fuel additives, and feedstock for fuel production, which include: diethylene glycol monomethyl ether (DEGME), ethylene glycol monomethyl ether (DGME), dimethylamine (DMA), dimethylamine hydrochloride (DMA-HCl), dimethylaminopropylamine (DMAPA), dimethyl carbonate (DMC), dimethyl ether (DME), dimethoxymethane (DMM), dimethylnitrosamine (DMNA), monoethylene glycol butyl ether (EGBE), monomethylamine (MMA), fatty acid methyl ester (FAME) polyisobutylenephenolic-styrene oxide ammonium acetate (PIBP-SOAA), methyl tert-butyl ethers (MTBE), poly(methyl methacrylate, polyoxymethylene dimethyl ether (PODE), and tert-butyl alcohol.

reaction with acid. Gasoline supplemented with MTBE had a relatively greater octane rating and it was a viable alternative for other aromatic-based octane boosters such as benzene and toluene, which are toxic and carcinogenic (Olah et al., 2011; Kazemi Shariat Panahi et al., 2019a). Like all oxygenated compounds, the addition of MTBE to gasoline allows for a reduction in emissions of $\mathrm{CO}, \mathrm{HCs}$, and $\mathrm{O}_{3}$ into the atmosphere.

Meanwhile, MTBE is synthesized by the reaction of methanol with isobutylene at about $100{ }^{\circ} \mathrm{C}$ in the presence of a mildly acidic catalyst such as polymeric acidic resins. Another compound similar to MTBE, tert-amyl methyl ether (TAME), is synthesized by reacting a mixture of isoamylene (IA), such as 2-methyl-1-butene (2M1B) or 2-methyl-2-butene (2M2B) with methanol in the presence of sulfuric acid $\left(\mathrm{H}_{2} \mathrm{SO}_{4}\right)$ resin. The unique advantage of TAME is that it satisfies three major characteristics of reformulated gasoline fuel namely oxygenation, reduction of volatility, and elimination of photochemically reactive and volatile olefins (Arteconi et al., 2011). While substitution of a MTBE blend ( 2 wt. $\%$ of $\left.\mathrm{O}_{2}\right)$ with an equivalent amount of TAME in gasoline resulted in similar exhaust gases (i.e., $\mathrm{CO}, \mathrm{HC}$, and $\mathrm{NO}_{\mathrm{x}}$ ) emissions, VOCs and evaporative toxic air pollutants (i.e., 1,3-butadiene, acetaldehyde, benzene), total toxic emissions, evaporative hot soak and formaldehyde emissions, were increased by $28 \%$ (Koehl et al., 1993).

Furthermore, dimethyl carbonate (DMC), a derivative of methanol, is a diesel additive that when combined with diesel fuel, there are improvements in emissions and performance. The DMC compound is synthesized through transesterification of ethylene carbonate with methanol. While DMC has no effect on $\mathrm{HC}$ emissions with its use as a fuel additive, there is a decrease in $\mathrm{CO}$ and $\mathrm{NO}_{\mathrm{X}}$ emissions from combustion of 
diesel as well as soot production (Lï et al., 2005; Westbrook et al., 2006). Overall, combustion of DMC-diesel blends resulted in production of less emission. Generation of particulate matters (PMs) increased when DMC was included in amounts of greater than 5\% (Lü et al., 2005; Nibin et al., 2005; Arteconi et al., 2011). Diethylene glycol methyl ether (DGME) or diglyme is a diesel cetane booster and oxygenate that can be manufactured through catalytic transformation of DME and ethylene oxide at 1-1.5 MPa at a temperature of 50 to $60{ }^{\circ} \mathrm{C}$ (Mangelsdorf et al., 2002). There, however, have been many reports that DGME is a toxic compound. The major impediment for using DGME in a fuel blend is the toxicity of the compound to humans and its high critical solubility temperature that hampers miscibility with diesel resulting in phase separation even at temperatures of less than $0{ }^{\circ} \mathrm{C}$.

Dimethoxymethane (DMM) is commercially produced by acetalization of formaldehyde and methanol at high temperatures utilizing a complicated multistep process. Alternatively, DMM can be manufactured using a one-step selective oxidation process for methanol conversion to formaldehyde followed by acetalization of formaldehyde with another methanol molecule in the presence of an acidic catalyst (Dehghani et al., 2018). The DMM compound is a stable pro-cetane that enhances the cetane number and $\mathrm{O}_{2}$ content of diesel that when used (at a $30 \%$ blend) results in a reduction in both $\mathrm{NO}_{\mathrm{x}}$ and $\mathrm{PM}$ emissions in direct-injection diesel engines. The use of DMM-diesel blend requires no alterations in the fuel supply and combustion systems of diesel engines (Zhu et al., 2008). Zhu et al. (2008) reported that conventional diesel engines powered with DMM-diesel blend (v/v, 30\%) had less CO and smoke emissions with no effect on $\mathrm{NO}_{\mathrm{x}}$ emission.

A higher homologue of DMM, polyoxymethylene dimethyl ethers $\left(\mathrm{PODE}_{n}\right.$, $n>1$ ), is available with relatively similar $\mathrm{O}_{2}$ content but a greater cetane number and lesser vapor pressure than DMM. These desirable characteristics make $\mathrm{PODE}_{3-5}$ safe green additives to diesel fuel. The $\mathrm{PODE}_{3-5}$ compounds can be synthesized from the end-group $\left(-\mathrm{CH}_{3}\right)$ and chain-group $\left(-\mathrm{CH}_{2} \mathrm{O}-\right)$ of DMM or methanol and formaldehyde or paraformaldehyde donors, respectively, in the presence of an acidic ionic catalyst, cation exchange resins, hydrochloric acid $(\mathrm{HCl}) /$ sulfuric acid $\mathrm{H}_{2} \mathrm{SO}_{4}$, or molecular sieves (Schelling et al., 2005; Burger et al., 2010; Qi et al., 2011; Zheng et al., 2013). Paraformaldehyde is a derivative of formaldehyde, which is commercially produced through evaporation of a 37 to $44 \%$ aqueous solution of formaldehyde in an elaborate vacuum distillation unit to prevent extensive loss of formaldehyde. The highly concentrated solution is cooled, flaked, dried, ground, and packed. Paraformaldehyde can be also produced by passing a vapor feed of high formaldehyde content (60-90\% by weight of formaldehyde) through a formaldehyde-immiscible organic liquid quenching medium containing acidic or alkaline material as polymerization catalyst. The quenching medium is then fed to a settling chamber to separate the condensed and polymerized formaldehyde i.e., paraformaldehyde (Sze, 1966). Hexamine or hexamethylenetetramine, a reaction product of formaldehyde and $\mathrm{NH}_{3}$, is the main component of hexamine fuel tablet. This high-density solid fuel burns without smoke, does not liquefy when burning, and leaves no ashes.

It is commonly accepted that traditional liquid and solid rocket motors suffer from certain issues such as difficulties with thrust control and termination in these types of engines (Novozhilov et al., 2011). Although, liquid systems provide high performance, they require sophisticated and expensive plumbing. On the other hand, solid systems require uniform mixing of fuel and oxidizer, which makes them unsafe. An alternative to such systems is hybrid systems that execute combustion in diffusion mode with initial separation of fuel and oxidizer that are generally in solid and liquid states, respectively. This arrangement or its modifications provide operationally flexible and safe solution at reasonable price. Polymers can be used as solid fuels in hybrid engines. When subjected to an external heat source for sufficient length of time, polymers undergo thermal degradation with random chain cleavage, producing different products in various concentrations. Poly (methyl methacrylate) (PMMA), the polymeric form of methyl methacrylate, exhibits a heat release capacity and total heat released of 376-514 J/g/K and $23.2 \mathrm{~kJ} / \mathrm{g}$, respectively, with material melting and volatilizing so that no residues left (Novozhilov et al., 2011). The high flammability of PMMA is due to its efficient depolymerization to produce monomers (>90\% yield). The complete combustion of the pyrolysis products is assisted by the $\mathrm{O}_{2}$ of the ester group, which also contributes to the formation of low volume of smoke. To produce MMA, acetone and hydrogen cyanide are first reacted to synthesize acetone cyanohydrin. Cyanohydrin is converted to methacrylamide sulfate by $\mathrm{H}_{2} \mathrm{SO}_{4}$, which is then reacted with a methanol/ $\mathrm{H}_{2} \mathrm{O}$ mixture and heated. A process called "Alpha" has been developed by Lucite International, which utilizes $\mathrm{CO}, \mathrm{C}_{2} \mathrm{H}_{4}$, and methanol. The Alpha process reduces the MMA production cost by up to $40 \%$ and includes a total of three major steps; two separate catalytic reactions and a complex series of distillations in the final product separation stage. In the first step, the feedstocks are reacted in the liquid phase at $1 \mathrm{MPa}$ and $100{ }^{\circ} \mathrm{C}$ in the presence of a homogeneous palladiumbased phosphine ligand catalyst. The product of this step, methylpropionate, is reacted with formaldehyde in the gaseous phase over a fixed bed heterogeneous catalyst in the presence of methanol to form MMA and $\mathrm{H}_{2} \mathrm{O}$ in the second step. MMA is then separated and purified using six distillation steps.

Isoprene is commercially produced from $\mathrm{C}_{4} \mathrm{H}_{8}$-containing $\mathrm{C}_{4}$ fractions and formaldehyde, which includes either the gas-phase high-temperature decomposition of 4,4-dimethyl-1,3-dioxane or concurrent liquid-phase decomposition of intermediate products. The latter decomposition is performed in a column reactor in the presence of an aqueous solution of phosphoric acid $\left(\mathrm{H}_{3} \mathrm{PO}_{4}\right)$ at about $160{ }^{\circ} \mathrm{C}$ and allows for a decrease in the cost of isoprene production by 1.5 times (Pavlov et al., 2011). Isoprene can be selectively oligomerized to produce a distribution of branched chain HCs. High density cyclic jet or diesel fuels can be generated by combination of an oligomerization catalyst with a metathesis catalyst Isoprene-derived fuels exhibit performance advantages, including increased density and volumetric net heat of combustion, compared to their conventional petroleum-based counterparts (Harvey, 2016).

Furthermore, the transesterification of a large variety of vegetable oils and animal fats containing fatty acid esters with methanol leads to the formation of fatty acid methyl esters (FAME), the constituents of biodiesel, and glycerol as the main by-product (Rahimzadeh et al., 2018; Tabatabaei et al., 2019a). Biodiesel can be blended with regular diesel fuel in any proportions to reduce the emission of $\mathrm{CO}, \mathrm{CO}_{2}, \mathrm{PM}, \mathrm{S}$ compounds as well as HCs that were not combusted. Limited availability of economically feasible feedstocks for the production of biodiesel continues to be a major challenge for the biodiesel industry (Hajjari et al., 2017; Rahimzadeh et al., 2018; Tabatabaei et al., 2019a). This limitation may be overcome by the production of ethylene $\left(\mathrm{C}_{2} \mathrm{H}_{4}\right)$ and $\mathrm{C}_{3} \mathrm{H}_{6}$ from ethanol or methanol, which can be processed together with petroleum oil feedstocks to produce fuels with reduced GHG emissions (Olah et al., 2011)

Additionally, the energy in methanol, ethanol, and DME fuels can be converted into electrical energy through electrochemical reactions of the hydrogen fuel with an oxidizing agent in an electrochemical cell, a technology known as fuel cells. Fuels cells such as direct dimethyl ether fuel cells (DDEFC), direct ethanol fuel cells (DEFC), and direct methanol fuel cells (DMFC) are currently the prototypes that are closest to being commercially available sources of liquid fuel that may function at ambient temperature (Serov and Kwak, 2010; James et al., 2018; McDonald and Hamdan, 2019; Schechter et al., 2019). Although the time for potential scale-up and commercialization of DMFC appears to be nearing, the application of platinum (Pt) and $\mathrm{Pt}$ alloys on both sides of the membrane electrode assemblies makes the final fuel cell device expensive and, therefore, the competitiveness with existing technologies is questionable. The toxicity, high flammability, ease of crossover of methanol from the anode to the cathode side of the fuel cell device are other impediments for large scale DMFC commercial development. In recent decade, there has been a newer type of fuel cell developed that has the capacity for operation with polyols as an energy source, which have some advantages when compared to the use of methanol in fuel cells (Serov and Kwak, 2010; Lamy and Coutanceau, 2012). Some of the advantages of polyol use include a $17 \%$ greater theoretical capacity (4.8 against $4 \mathrm{Ah} / \mathrm{mL}$ for methanol) and higher boiling point (198 compared to $65{ }^{\circ} \mathrm{C}$ for methanol), and consequently, greater safety. Furthermore, each $\mathrm{C}$ of EG and glycerol carries an alcohol group, the partial oxidation of which to oxalate and mesoxalate in alkaline medium and oxalic and mesoxalic acids in acid medium without $\mathrm{CO}_{2}$ or carbonate ion $\left(\mathrm{CO}_{3}^{2-}\right)$ emission, i.e., without $\mathrm{C}-\mathrm{C}$ bond breaking, exchanges eight and 10 electrons, respectively. In contrast, their complete oxidation to $\mathrm{CO}_{2}$ or $\mathrm{CO}_{3}^{2-}$ involves 10 and 14 exchanged electrons for EG and glycerol, respectively, against six electrons during complete oxidation of the simplest alcohol, i.e., methanol, to $\mathrm{CO}_{2}$. This property allows the utilization of up to $80 \%$ of whole energy available in these compounds without breaking $\mathrm{C}-\mathrm{C}$ bonds. 


\section{Ethanol}

\subsection{Background and possibilities}

Ethanol, a biofuel, is the only alcohol that is used as human beverage unless it is denatured. The use of ethanol as an illuminant in lamp oil as well as heating source dates back to the $17^{\text {th }}$ century (Kazemi Shariat Panahi et al., 2019a). Thereafter, ethanol was used as fuel in the first American ICE prototype designed by Samuel Morey and that designed by the German engineer, Nikolas August Otto, in 1826 and 1860, respectively (Cummins, 1989; Hardenberg and Morey, 1992; Kazemi Shariat Panahi et al., 2019a). In 1896, Henry Ford and colleagues built their first quadricycle automobile that had an ethanol-powered engine (Kazemi Shariat Panahi et al., 2019a). Since that time, various ethanol blends have been used in different types of gasoline-powered vehicles (Balat et al., 2008; Kazemi Shariat Panahi et al., 2019a). Numbers of gasoline-powered automobiles that were built exceeded those of the alcohol-powered counterparts mainly due to discovery of oil deposits that led to gasoline being at an economically competitive advantage in countries with oil deposits as compared to use of ethanol as a fuel source.

The circumstances of World Wars and oil crises due to trade barriers highlighted the importance of the alcohol industry for energy independence and sustainability (Kazemi Shariat Panahi et al., 2019a). Indeed, interests in using ethanol as a transportation fuel were revived in the 1970s due to an increase in oil prices as a result of international trade impediments, simplicity and availability of ethanol production and distillation technologies, as well as compatibility of ethanol with ICE (Olah et al., 2011; Kazemi Shariat Panahi et al., 2019a). More specifically, ethanol provides for a greater compression ratio, shorter burn time, and greater lean burn in ICE than gasoline. These advantages (Table 3) result from the broader ethanol flammability, higher octane number, greater flame speeds and heats of vaporization (MacLean and Lave, 2003). It is worth to mention that octane number is a standard measure of quality that indicates anti-knock properties of a given fuel. The higher the octane number, the less is the susceptibility of the fuel to explosion due to premature burning in the cylinder. Ethanol, however, has only $65 \%$ of the energy density of gasoline (albeit 25\% greater energy content than methanol), lesser vapor pressure (making "cold starts" difficult), and lesser flame luminosity (MacLean and Lave, 2003). Other disadvantages of ethanol include corrosiveness and unlimited miscibility with water (MacLean and Lave, 2003; Rahimpour et al., 2019). While engine "cold starting" can be greatly improved by blending ethanol with gasoline, the increase in the volatility of ethanol (Reid vapor pressure) can result in increase in evaporative emissions after combustion (MacLean and Lave, 2003).

Currently, ethanol is used as a fuel or gasoline extender, also known as gasohol and octane booster. It is used in reformulated fuel programs to oxygenate gasoline in winter months, replacing MTBE. Traditionally, ethanol is blended with gasoline $(5.7 \%, \mathrm{v} / \mathrm{v})$ to generate $2 \%$ by weight of $\mathrm{O}_{2}$ but currently, $7.7 \%$ to $10 \%$ ethanol is blended with gasoline (Kazemi Shariat Panahi et al., 2019a). In the USA, gasohol or E10 is a blend of gasoline and ethanol at the ratio percentage of 90:10 (v/v) whereas gasohol in Brazil contains a greater amount of ethanol (24\%, v/v) (Dias De Oliveira et al., 2005). Indeed, in flexible fuel vehicles (FFVs), which have port fuel injection type of engines and a spark ignition system, gasoline-ethanol blends with ethanol contents as high as $85 \%$ (E85) can be used as a fuel (MacLean and Lave, 2003). Gasolineethanol blend programs have been developed in countries other than the USA including Australia, Canada, China, Columbia, India, Paraguay, Peru, Sweden, and Thailand (Balat et al., 2008).

Approximately $80 \%$ of the global production of ethanol comes from fermentations while the remaining $20 \%$ comes from chemical synthesis via hydration of $\mathrm{C}_{2} \mathrm{H}_{4}$ from natural gas and petroleum. In 2018, total global ethanol production was approximately 108.14 billion L mainly from corn and sugarcane fermentations that was about a $118 \%$ increase in production when compared to the amount produced in 2007 (Fig. 2). The total amount of biofuel production reached 143 billion liters in 2017 ( 9 times increased compared to its production in 2000) with the ethanol as the largest biofuel (accounting for about 95\% of global biofuel production in 2008) (Balat et al., 2008; WBA, 2018). The world leading fuel bioethanol producers are the USA and Brazil producing more than $85 \%$ of the total amount of bioethanol produced globally from 2007 to 2018 (AFDC, 2018; RFA, 2019). China is the fourth largest
Table 3.

Fuel properties of ethanol.

\begin{tabular}{ll}
\hline Chemical formula & \\
Structure & 46.068 \\
& 78.37 \\
Molar mass $(\mathrm{g} / \mathrm{mol})$ & -114.1 \\
Boiling point $\left({ }^{\circ} \mathrm{C}\right)$ & 52.2 \\
Melting point $\left({ }^{\circ} \mathrm{C}\right)$ & 789 \\
Composition, weight $\% \mathrm{C}$ & 365 \\
Density $\left(\mathrm{kg} / \mathrm{m}^{3}\right)$ & 17 \\
Ignition temperature $\left({ }^{\circ} \mathrm{C}\right)$ & $11.2 \times 10^{-4}$ \\
Flash point $\left({ }^{\circ} \mathrm{C}\right)$ & $1.4 \times 10^{-6}$ \\
Thermal expansion coefficient $(\mathrm{K}-1)$ & $4.3,19$ \\
Viscosity $\left(\mathrm{m}^{2} / \mathrm{s}\right)$ & 29.7 \\
Flammability limits, vol.\%, lower, higher & 9 \\
Calorific value $(\mathrm{MJ} / \mathrm{kg})$ & 5.95 \\
Air-fuel ratio $(\mathrm{kg} / \mathrm{kg})$ & 0.92 \\
Vapor pressure & 108.6 \\
Heat of vaporization $(\mathrm{MJ} / \mathrm{kg})$ & \\
Research octane $\mathrm{No}$. &
\end{tabular}

ethanol producer with the amount produced being only $2.7 \%$ of the global ethanol production in the same period (AFDC, 2018). However, China improved its production share in 2018 reaching $4 \%$ of global fuel ethanol while the USA and Brazil roughly kept the similar global share as 2007 2018 (i.e., 84\%) (RFA, 2019) (Fig. 2).This marked difference in productivity between USA-Brazil and China may be due to feedstock availability and cost. The abundance of sugarcane and corn in Brazil and the USA, respectively, appear to facilitate the production of bioethanol in both countries.

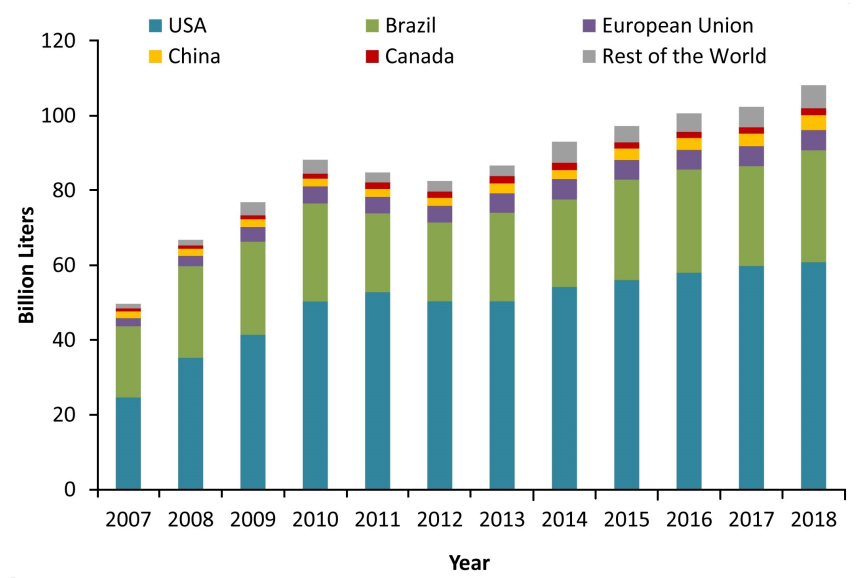

Fig. 2. Global ethanol production (billion liters) from 2007 to 2018. Source: AFDC (2018) and RFA (2019).

\subsection{Chemical synthesis of ethanol}

Ethanol can be manufactured through chemical synthesis by hydration of $\mathrm{C}_{2} \mathrm{H}_{4}$ from natural gas, syngas, and cracking of crude oil. The substrate, $\mathrm{C}_{2} \mathrm{H}_{4}$, is converted to ethanol using steam and a catalyst, which often results in generation of toxic by-products and requires purification to remove undesirable by-products and $\mathrm{H}_{2} \mathrm{O}$. The utilization of $\mathrm{C}_{2} \mathrm{H}_{4}$ for ethanol 
production is unattractive due to the crude oil prices; however, use of lignocellulosic biomass and coal as feedstocks for chemical synthesis of ethanol is generating some interests. The lignocellulosic biomass and coal feedstocks can be converted into ethanol through use of three methods (Subramani and Gangwal, 2008): (i) gasification of lignocellulosic biomass and coal to syngas, followed by direct conversion of syngas into ethanol in a process that involves selective hydrogenation of $\mathrm{CO}$ to ethanol in the presence of a catalyst; (ii) conversion of syngas (i.e., $\mathrm{CO}$, and $\mathrm{H}_{2}$ ) into methanol followed by methanol homologation, which involves reductive carbonylation of methanol in the presence of a redox catalyst, a C-C bond formation process, to generate ethanol; and (iii) a multistep ENSOL process, in which syngas is first transformed into methanol in the presence of a commercial methanol synthesis catalyst, followed by carbonylation of methanol into acetic acid in the second step, and hydrogenation of acetic acid to ethanol. While methanol homologation and ENSOL processes for chemical synthesis of ethanol have been scaled up to pilot scale (Subramani and Gangwal, 2008), both technologies are plagued with product yields in small amounts and selectivity, and high operating cost due to the great amount of energy consumption and use of expensive catalysts such as Rh.

\subsection{Microbial production of ethanol}

Commercial fermentative production of ethanol has a long history and is a common practice, which is mainly dependent on edible source of sugar or starch. However, fuel application of this ethanol also known as the first generation bioethanol has sparked severe debates on its sustainability aspects including its adverse impacts on food availability as well as the prices of food commodities. Therefore, efforts have been put in developing the second generation ethanol from lignocellulosic feedstocks.

\subsubsection{Ethanol-producing microorganisms}

Native and engineered strains of microorganisms used for ethanol production are the ethanologens: Candida brassicae, Candida shehatae, Clostridium sordelli, Clostridium sphenoides, Clostridium sporogenes, E. coli, Erwinia amylovora, Klebsiella aerogenes, Klebsiella oxytoca, Kluyveromyces fragilis, Mucor indicus, Pachysolen tannophilus, Pichia stipitis, Saccharomyces cerevisiae, Spirochaeta aurantia, Spirochaeta litoralis, Spirochaeta stenostrepta, and Zymomonas mobilis. Efficient ethanologenic microorganisms can be precisely described based on values for fermentation performance variables such as ethanol production and tolerance $(>40 \mathrm{~g} / \mathrm{L})$, genetic stability, inhibitor tolerance, growth rate, tolerance towards osmotic stress/more acidic $\mathrm{pH} / \mathrm{higher}$ temperature values, productivity $(>1 \mathrm{~g} / \mathrm{L} / \mathrm{h})$ and yield ( $>90 \%$ of theoretical), and specificity range (Dien et al., 2003; Balat et al., 2008). Some common and efficient ethanologenic microorganisms along with the advantages and limitations associated with their use are reported in Table 4.

Although the use of S. cerevisiae for ethanol production from starch derived sugars and sugarcane derived sucrose has been commercially dominant, the opposite is the case for sugars derived from lignocellulosic feedstocks. Even though there is a long history and great characteristics of $S$. cerevisiae for ethanol fermentation, the wild-type $S$. cerevisiae does not metabolize xylose. This limitation is significant because xylose is the second most common fermentable sugar after glucose in lignocellulose hydrolysates. Consequently, the yield of ethanol from lignocellulosic hydrolysate is poor when the biocatalyst is $S$. cerevisiae, thus, highlighting the need for the generation and use of engineered $S$. cerevisiae with improved xylose metabolism characteristics for ethanol fermentation with lignocellulosic biomass hydrolysates (Matsushika et al., 2009). Currently, E coli, K. oxytoca, and Z. mobilis are the most promising bacteria for commercial production of ethanol (Alia et al., 2019; Kumar et al., 2019). E. coli and $K$. oxytoca are the first two species that can utilize a broad range of substrates including pentose and hexose sugars. Native forms of these bacteria, however, do not function to produce ethanol selectively (Table 4). In contrast, $Z$. mobilis can quickly uptake sugars and is not inhibited by high concentrations of ethanol. The major impediment for the commercial application of this microorganism in production of ethanol is its narrow-range of substrate and the production of high concentrations of by-products (Table 4). Interestingly, Z. mobilis is the only microorganism that metabolizes glucose anaerobically via the Entner-Doudoroff (ED) instead of the glycolytic or Embden-Meyerhoff-Parnas pathway (Dien et al., 2003).
Compared to Z. mobilis, there is utilization by E. coli of pyruvate formatelyase and lactate dehydrogenase to channel pyruvate toward a mixture of fermentation products such as ethanol, acetic acid (AA), lactic, succinic, and formic acid. Notably, the key issue in fermentation is the regeneration of the oxidized form (NAD+) of NADH so that glycolysis may be sustained. With use of $E$. coli, therefore, there is generation of by-products such as AA and succinic acid (SA) to maintain the redox balance during growth and fermentation (Dien et al., 2003).

There are basically two approaches to increase utilization of pentose sugars and improve ethanol production from lignocellulosic feedstock (Dien et al., 2003; Jeffries and Jin, 2004). With the first approach, there is the aim to introduce the pentose metabolic pathway into ethanologens that lack the capacity to metabolize pentose sugars whereas with the second approach the aim is to improve ethanol yields in microorganisms with the natural capacity to ferment both 5- and 6-C sugars to ethanol. To facilitate metabolic modifications in fermenting microorganisms and enhance pentose sugars utilization as well as ethanol productivity and yield, functional genomics including transcriptomics, proteomics, metabolomics, and fluxomics have been utilized. More specifically, these fields of molecular biology provide very useful approaches in understanding the indepth physiology of these microorganisms as well as making relevant metabolic alterations for improvements in microbe functionality for these fermentation purposes (Matsushika et al., 2009). Recently, more sophisticated and efficient approaches for genome editing such as CRISPR/Cas9 are being used to modify Z . mobilis and other fermenting microorganisms to enhance fermentation performance (Borodina and Nielsen, 2014; Yang et al., 2016).

\subsubsection{Commercial fermentative production of ethanol}

The first demonstration lignocellulosic ethanol plant has been in operation in Canada since 2004 (Tampier et al., 2004). Since then many pilot or commercial lignocellulosic ethanol plants have been constructed and are in operation in different parts of the world. In the SEKAB Company located in Ornskoldsvik, Sweden, there is use of acid (i.e., $\mathrm{H}_{2} \mathrm{SO}_{4}$ or $\mathrm{SO}_{2}$ ) and steam pretreatment (i.e., $200{ }^{\circ} \mathrm{C}$ ) technologies to de-lignify lignocellulose and release hemicellulose derived sugars from wood chips and sugarcane bagasse. Subsequently, solid residues (i.e., cellulose and lignin) are separated and subjected to enzymatic hydrolysis to release the remaining sugars from the cellulose component of the solid residue. The low pH slurry (containing pentose and hexose sugars) is neutralized and subjected to simultaneous saccharification and fermentation (SSF) or separate hydrolysis and fermentation (SHF) to produce ethanol using recombinant $S$. cerevisiae. At the end of the process, ethanol is recovered by use of a distillation process while solid residues, mainly lignin, are used as a biofuel or are refined into other products. Remnants of ethanol fermentation, solubles or extractives, may be degraded by microorganisms for production of biogas, which may be used for energy generation in the ethanol plant or marketed to power plants to generate additional revenues (http://www.sekab.com/biorefinery/e-tech-process/).

Some lignocellulose-based ethanol plants that are currently operating or have operated in the past at pilot or commercial scales include: Abengoa in Hugoton, KS (enzymatic hydrolysis of corn stover to ethanol); Beta Renewables in Sampson County, NC (enzymatic hydrolysis of arundo and switchgrass to ethanol); DuPont Biofuel Solutions in Nevada, IA (enzymatic hydrolysis of corn stover to ethanol); and POET in Emmetsburg, IA (enzymatic hydrolysis of corn stover and corn cobs to ethanol). Currently, breakdown of lignocellulose to sugars and subsequent fermentation to ethanol costs as much as three times more than sugar- and starch-containing feedstocks when capital costs are considered. Additionally, the economic cost for current technology for delignification of lignocellulose and hydrolysis of cellulose to fermentable sugars cannot be offset by the lesser economic cost of lignocellulose as a feedstock. It, however, is envisaged that knowledge gained from the commercial/pilot plants that are currently operational with regard to cost, feedstock handling and logistics, product yield and productivities, challenges and proffered solutions, will be eventually be used to help reduce production cost of cellulosic-produced ethanol. 
Table 4.

Advantages and limitations of ethanologens for commercial production of bioethanol.

\begin{tabular}{|c|c|c|c|}
\hline Microorganism & Advantages & Limitations & Reference \\
\hline \multicolumn{4}{|l|}{ Yeast } \\
\hline Saccharomyces cerevisiae & $\begin{array}{l}\text {-High bioethanol production from } 6 \text {-carbon sugars } \\
\text {-High tolerance to inhibitors }(\geq 10 \% \mathrm{v} / \mathrm{v} \text {, ethanol included) such } \\
\text { as compounds in the acid hydrolysates of lignocellulosic } \\
\text { feedstocks } \\
\text {-Application of residual cell mass as animal feed additive } \\
\text {-Commercial application for non-lignocellulosic feedstocks } \\
\text {-GRAS a } \\
\text {-High alcohol yield (typically } 90 \%) \\
\text {-Amenability to genetic engineering }\end{array}$ & $\begin{array}{l}\text {-Unable to consume 5-carbon sugars, such as arabinose } \\
\text { and xylose } \\
\text {-Unable to consume celloligosaccharides } \\
\text {-Inadequate yield of ethanol from lignocellulosic } \\
\text { hydrolysates } \\
\text {-Susceptible to high temperatures of enzyme hydrolysis } \\
\text { (in case of SSF) }\end{array}$ & $\begin{array}{l}\text { Hahn-Hägerdal et al. (2006) } \\
\text { Katahira et al. (2006) } \\
\text { Balat et al. (2008) } \\
\text { Kazemi Shariat Panahi et al. (2019b) } \\
\text { Kumar et al. (2019) }\end{array}$ \\
\hline
\end{tabular}

Bacteria

-Rapid and efficient production of ethanol with yields and
concentrations up to $97 \%$ and $120 \mathrm{~g} / \mathrm{L}(12 \% \mathrm{w} / \mathrm{v})$, respectively
-A unique energy-uncoupled growth
-High tolerance to ethanol $(\mathrm{v} / \mathrm{v}, \geq 14 \%)$ due to hopanoids-
containing plasma
-Higher ethanol yield (5-10\% more ethanol per fermented
glucose) and specific productivity (up to $2.5-5 \times)$ than $S$.
cerevisiae
-No requirement for controlling $\mathrm{O}_{2}$ addition during fermentation
-Simple nutritional needs and some strains require only
pantothenate and biotin for growth
-Successful industrial scaled trials
-GRAS
-Amenability to genetic engineering

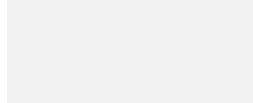

Klebsiella oxytoca

$$
\begin{aligned}
& \text {-Ethanol production at yields approaching theoretical maxima } \\
& \text {-Capable of growing at a pH at least as low as } 5.0 \text { and } \\
& \text { temperatures as high as } 35^{\circ} \mathrm{C} \\
& \text {-Required less than half of the fungal enzymes required by } S \text {. } \\
& \text { cerevisiae to achieve equivalent fermentation rates and yields } \\
& \text {-Broad substrate range (pentoses, hexoses, cellobiose, } \\
& \text { cellotriose, xylobiose, xylotriose, and arabinosides) } \\
& \text {-Minimal by-products formation and nutritional requirements } \\
& \text {-Reduction of the process cost by growth medium alteration and } \\
& \text { reduction of the demand for supplemental enzymes. }
\end{aligned}
$$

-Unable to consume 5-carbon sugars, such as arabinose and xylose

-Intolerance to inhibitory compounds as well as AA in the acid hydrolysates of lignocellulosic feedstocks -Low ethanol yield and productivity of recombinant strains in presence of mixed sugars and inhibitors -Limited substrate range (glucose, fructose, and sucrose)

-Formation of levan polymer and by-products such as AA, acetoin, glycerol, and sorbitol

-Less hardy cultures, compared to $S$. cerevisiae -Narrow $\mathrm{pH}$ (neutral) range

-No commercial plant

-Lack the pathway required for the production of ethanol as the main fermentation product

-Narrow temperature and $\mathrm{pH}(6.0-8.0)$ growth ranges

-Less hardy cultures, compared to $S$. cerevisiae

-Negative public perceptions (the danger of E. coli strains)

-Formation of by-products such as acetic and succinic acids

-The lack of data on the use of residual E. coli cell mass as an ingredient in animal feed

-Interference of co-fermentation by repression catabolism

-Limited tolerance for inhibitors (ethanol included)

-Not yet proven genetic stability

-No commercial plant

-Lack the pathway required for production of ethanol as the main fermentation product.

-No commercial plant
Swings and De Ley (1977)

Gunasekaran and Raj (1999)

Joachimsthal and Rogers (2000)

Dien et al. (2003)

Doran-Peterson et al. (2008)

Agrawal et al. (2011)

Alia et al. (2019)

Dien et al. (2003)

Kazemi Shariat Panahi et al. (2019b) Kumar et al. (2019)

${ }^{\mathrm{a}}$ Generally recognized as safe

\section{- Fermentation of lignocellulosic biomass and product recovery}

Thermotolerant microorganisms capable of generating optimal ethanol yields and productivity, tolerating high ethanol titers and lignocellulose derived microbial inhibitory compounds such as furfural, hydroxylmethyl furfural (HMF), ferulic acid, vanillin, and coumaric acid in fermentation broth, are ideal for lignocellulose-based bioethanol industry (Ezeji et al., 2007; Okonkwo et al., 2016). Indeed, different processes and metabolic engineering strategies are being developed to facilitate complete utilization of sugars present in lignocellulosic biomass hydrolysates and conversion into target products such as ethanol (Sarkar et al., 2012; Kazemi Shariat Panahi et al., 2019a). Based on the enzymatic-fermentation approach, the fermentation of pretreated lignocellulosic feedstocks can be performed by either using SHF or SSF (Table 5). The use of unconventional method, SSF, allows for generation of desirable yields of ethanol because sugars generated by enzymes are fermented to ethanol in real-time, thereby alleviating end-product inhibition by cellobiose, glucose, and xylose during enzymatic hydrolysis of pretreated lignocellulosic feedstocks (Kazemi Shariat Panahi et al., 2019b). Suboptimal temperatures for cellulase activity, however, are typically imposed for SSF processing involving $S$. cerevisiae and Trichoderma reesei derived cellulase with an optimal temperature for activity being $55^{\circ} \mathrm{C}$. The SSF is typically performed at $37^{\circ} \mathrm{C}$ to improve cellulase activity at this temperature resulting in lesser ethanol tolerance and greater distillation costs due to the relatively lesser ethanol concentration in the fermentation broth (Hamelinck et al., 2005). While bacteria function is optimal at a narrow $\mathrm{pH}$ range of 6.0 and 7.5, fungi and yeast function at a wider $\mathrm{pH}$ range and tolerate an acidic $\mathrm{pH}$ as low as 3.5 (Aminifarshidmehr, 1996). In contrast, optimal temperature conditions for cellulase enzymes for hydrolysis of pretreated lignocellulose and fermentation of reducing sugars to ethanol can be applied conveniently with conventional methods (i.e., SHF) (Bjerre et al., 1996; Hamelinck et al., 2005; Kazemi Shariat Panahi et al., 2019b). For example, cellulase preparations obtained from T. reesei have an optimal activity at $\mathrm{pH} 4.5$ and $55^{\circ} \mathrm{C}$. To mitigate disparity in the SSF process conditions and enhance ethanol productivity, there should be 
Table 5.

Advantages and limitations of separate hydrolysis and fermentation (SHF) or simultaneous saccharification and fermentation (SSF) for production of ethanol.

\begin{tabular}{|c|c|c|}
\hline Configuration & Advantages & Limitations \\
\hline $\mathrm{SHF}^{\mathrm{a}}$ & $\begin{array}{l}\text {-Minimized inter-steps interactions } \\
\text {-Optimum operating condition for each step }\end{array}$ & $\begin{array}{l}\text {-Lower yields of reducing sugar due to end-product inhibition } \\
\text {-Higher chance of contamination due to prolonged process } \\
\text {-Higher costs and higher enzyme consumption } \\
\text {-Two-stage bioethanol production from pentose and hexose sugars at different reactors }\end{array}$ \\
\hline $\operatorname{SSF}^{\mathbf{b}}$ or SSCF ${ }^{\mathbf{c}}$ & $\begin{array}{l}\text {-Lower costs } \\
\text {-Reduction in the number and the volume of the required reactors } \\
\text {-Overcoming the end-product inhibition of saccharification step } \\
\text {-Higher yields of hydrolysis with lower enzyme requirement } \\
\text {-Higher yields of ethanol (about } 5 \mathrm{wt} \% \text { ) } \\
\text {-Lower requirement for sterile conditions due to immediate consumption of } \\
\text { generated glucose for bioethanol production } \\
\text {-Shorter process time } \\
\text {-Simultaneous consumption of pentose and hexose sugar at a same reactor } \\
\text { (SSCF) }\end{array}$ & $\begin{array}{l}\text {-No optimum temperature conditions for the best results of both saccharification and fermentation } \\
\text { can be reached at the same time. } \\
\text {-Low } \mathrm{pH}(<5) \text { and high temperature }\left(>40^{\circ} \mathrm{C}\right) \text { which is favorable for enzymatic hydrolysis can } \\
\text { inhibit the formation of lactic acid and may adversely affect the yeast cell growth }\end{array}$ \\
\hline
\end{tabular}

${ }^{\text {a }}$ Separate hydrolysis and fermentation

${ }^{\mathbf{b}}$ Simultaneous saccharification and fermentation

${ }^{c}$ Simultaneous saccharification and co-fermentation

use of thermotolerant microorganisms such as Candida lusitaniae, Kluyveromyces marxianus, or Z. mobilis for the fermentation of generated sugars to ethanol (Bjerre et al., 1996; Hamelinck et al., 2005; Balat et al., 2008; Sarkar et al., 2012; Kazemi Shariat Panahi et al., 2019a and b). These microorganisms, however, are not as robust and ethanologenic as $S$. cerevisiae.

The SSF process involves simultaneous fermentation of 5- and 6-carbon sugars with a process termed simultaneous saccharification and cofermentation (SSCF) (Kazemi Shariat Panahi et al., 2019b). The SSCF process is efficient and designed to sustain glucose concentrations in the bioreactor low, reduce catabolite repression of microbial function, and enhance xylose conversion into target products (Liu and Chen, 2016). While little to no data from a pilot scale plant are available, there is a closely related process known as consolidated bioprocessing (CBP) or direct microbial conversion (DMC) in which cellulase production, hydrolysis of pretreated lignocellulosic feedstock, and ethanol fermentation take place in a single reactor (Bjerre et al., 1996; Kazemi Shariat Panahi et al., 2019b). Microorganisms such as Aspergillus sp., Clostridium thermocellum, Fusarium oxyporum, Neurospora crassa, Paecilomyces sp., and Zygosaccharomyces rouxii, have been used either in mono- or co-culture forms in CBP processes. Although CBP is less capital intensive than the conventional process due to savings from enzyme purchases, the process is not efficient because of the long fermentation time (3-12 d), small ethanol concentrations (0.8-60 g/L), and large amounts of unwanted byproducts such as AA and lactic acid (LA) (Szczodrak and Fiedurek, 1996; Kazemi Shariat Panahi et al., 2019b). As a result, the pilot plant based on CBP configuration operated by Mascoma Corporation headquartered in Lebanon New Hampshire, USA, with a capital cost of USD 232 million to turn hardwood pulp directly to ethanol is sub-optimal as compared to the installation capacity. Some examples of conversion of various lignocellulosic feedstocks to ethanol using CBP processing configurations are presented in Table 6.

\subsection{Ethanol derivatives as fuel components: production, applications, and performance}

Although ethanol is a fuel additive for gasoline, its hygroscopic nature creates problems during transportation, especially in moist environments such as marine motor fuels. While ethanol has been transported via pipelines in the USA and Brazil, its corrosive nature and tendency to absorb water and impurities in the pipelines often result in excessive corrosion of the pipeline system. Use of stainless steel pipes has been recommended as a viable strategy to mitigate corrosion in fuel pipelines that are used to transport ethanol and gasoline-ethanol blend fuels. Even stainless steel pipelines, however, have stress corrosion cracking after use for a considerable length of time. Consequently, gasoline is blended with ethanol in a designated facility and transported to dispensing gas (filling) stations using tanker trucks. Cost effective conversion of ethanol to other fuel chemicals (Fig. 3), however, may be a more effective strategy for addressing ethanol induced corrosion problems.

Ethanol can either be acid esterified or dehydrated in the presence of a $\mathrm{Cu}$ catalyst at high temperatures to generate ethyl acetate, which has a greater heat of combustion than ethanol (Jones, 2011). The stability and octane rating of gasoline-ethanol blends (with ethanol contents as high as E20) is considerably improved by the addition of ethyl acetate (Amine et al., 2017). The addition of other esters such as iso-butyl acetate, $n$-butyl acetate, or methyl acetate to gasoline resulted in improvement of its octane number and oxidation stability. This is a desirable characteristic that contributes to an enhancement in fuel storage capacity and stability of fuel vapor pressure (Amine et al., 2013; Dabbagh et al., 2013). Notably, with use of these esters, there is a reduction in emissions of aldehydes, $\mathrm{CO}$, and ketones due to the high oxidation state of these compounds allowing for use in automobiles with no requirements for engine modifications (Dabbagh et al., 2013).

Ethanol can also be converted into $\mathrm{C}_{2} \mathrm{H}_{4}$ in the presence of an aluminabased catalyst in a tubular fixed bed reactor at a temperature range between 240 and $450{ }^{\circ} \mathrm{C}$ or with addition of $\mathrm{TiO}_{2} / \mathrm{Al}_{2} \mathrm{O}_{3}$ catalysts in a microchanne reactor (Chen et al., 2007; Morschbacker, 2009; Kagyrmanova et al., 2011). The produced $\mathrm{C}_{2} \mathrm{H}_{4}$ could then be converted into several fuel additive compounds such as diethanolamine (DEA), EG, glycerol, and glycol ethers (Fig. 3). Notably, fuel lubricating and anti-wear additives have been made from DEA or its derivatives for diesel or biodiesel fuels (Ball et al., 1999; Jung et al., 2016; Lagona and Loper, 2017; Levine et al., 2018). Glycol ethers are potential fuels that react with alcohols such as butanol, ethanol, methanol, or phenol, generating products with excellent fuel additive properties. An investigation by Gómez Cuenca et al. (2011) on effects of ethylene glycol ethers such as monoethylene glycol ethyl ether (EGEE) and diethylene glycol ethyl ether (DEGEE) on diesel fuel properties and emissions in diesel engines revealed that the addition of these compounds to fuels at $4 \mathrm{wt} . \%(\mathrm{v} / \mathrm{v})$ improved both lubricity and viscosity of diesel fuel. While the inclusion of EGEE resulted in a decrease in the cetane number of the diesel fuel, the inclusion of DEGEE increased the number.

The MTBE compound used to be preferred for oxygenating gasoline due to its superb vaporization properties, however, the relatively greater solubility of MTBE in $\mathrm{H}_{2} \mathrm{O}$ and slow degradation in the environment detracted its use and resulted in increased use of bioethanol and its derivative, ethyl tert-butyl ether (ETBE), as oxygenated additives for gasoline (Olah et al., 2011; Kazemi Shariat Panahi et al., 2019a). The reaction of isobutylene with ethanol in the presence of an acid catalyst results in the production of ETBE. The reaction, however, is reversible and when this occurs, there is a side reaction involving dimerization of isobutylene and production of diisobutene (Françoisse and Thyrion, 1991) 
Table 6.

Conversion of different lignocellulosic feedstocks to bioethanol using different fermentation configurations.

\begin{tabular}{|c|c|c|c|c|c|c|c|}
\hline Configuration & Strain & Lignocellulosic substrate & Pretreatment method & Enzymatic hydrolysis & $\begin{array}{l}\text { Ethanol } \\
\text { yield }\end{array}$ & Scale & Reference \\
\hline \multirow{2}{*}{$\operatorname{SSCF}^{\mathrm{a}}$} & \multirow{2}{*}{$\begin{array}{l}\text { Saccharomyces } \\
\text { cerevisiae KE6-12 }\end{array}$} & \multirow{2}{*}{$\begin{array}{l}\text { Corncobs slurry } \\
\text { (WIS }{ }^{\mathbf{b}} \text { content of } 15 \% \text { ) }\end{array}$} & \multirow{2}{*}{$\begin{array}{l}\text { Dilute acid } \\
\left(0.6 \%{ }^{\mathbf{c}} \mathrm{SO}_{2}, 185^{\circ} \mathrm{C}, 5 \mathrm{~min}\right)\end{array}$} & \multirow{2}{*}{$\begin{array}{l}\text { Cellic Ctec-2 (95-CA-FPU d/g } \\
\text { enzyme and } 590 \text { BGL-IU } / g \text { enzyme) }\end{array}$} & $68 \%$ & $\begin{array}{l}30-\mathrm{L} \\
\mathrm{PDU}^{\mathrm{f}}\end{array}$ & \multirow{2}{*}{ Koppram et al. (2013) } \\
\hline & & & & & $56 \%$ & $\begin{array}{l}10-m^{3} \\
\text { Demo }\end{array}$ & \\
\hline SSCF & S. cerevisiae IPE003 & $\begin{array}{l}\text { Corn stover } \\
\text { (WIS content of 20\%) }\end{array}$ & Steam explosion & $\operatorname{ATAEA}^{\mathrm{g}}$ (15 FPU/g glucan) & $75.3 \%$ & Flask & Liu and Chen (2016) \\
\hline \multirow[t]{2}{*}{ SSCF } & \multirow[t]{2}{*}{$\begin{array}{l}\text { S. cerevisiae } \\
\text { TMB } 3400\end{array}$} & \multirow[t]{2}{*}{$\begin{array}{l}\text { Wheat straw } \\
\text { (WIS content of } 11 \% \text { ) }\end{array}$} & $\begin{array}{l}\text { Acid }\left(0.2 \% \mathrm{H}_{2} \mathrm{SO}_{4} \text {, room }\right. \\
\text { temperature, overnight, then } \\
\text { pressed to } 30 \mathrm{MPa})\end{array}$ & $\begin{array}{l}\text { Xylanase XL ( } 44 \text { FPU/g and BGL-37 } \\
\text { IU/g) } \\
\text { Novozyme } 188 \text { ( } 342 \text { BGL-IU/g) }\end{array}$ & $69 \%$ & $\begin{array}{l}2.5-\mathrm{L} \\
\text { bioreactor }\end{array}$ & Olofsson et al. (2010) \\
\hline & & & $\begin{array}{l}\text { Steam-pretreatment } \\
\left(190^{\circ} \mathrm{C}, 10 \mathrm{~min}\right)\end{array}$ & $\begin{array}{l}\text { ATAEA ( } 36 \mathrm{FPU} / \mathrm{g} \text { total glucan and } \\
78 \mathrm{BGL}-\mathrm{IU} / \mathrm{g} \text { total glucan) }\end{array}$ & & & \\
\hline \multirow{3}{*}{ SSCF } & \multirow{3}{*}{$\begin{array}{l}\text { S. cerevisiae } \\
\text { TMB3400 }\end{array}$} & \multirow{3}{*}{$\begin{array}{l}\text { Spruce wood } \\
\text { (WIS content of } 10 \% \text { ) }\end{array}$} & Acid $\left(2.5 \% \mathrm{SO}_{2}, 20 \mathrm{~min}\right)$ & $\begin{array}{l}\text { Celluclast ( } 35 \text { FPU/g and } 20 \text { BGL- } \\
\text { IU/g) }\end{array}$ & & & \\
\hline & & & \multirow[b]{2}{*}{ Steam $\left(210^{\circ} \mathrm{C}, 5 \mathrm{~min}\right)$} & Novozyme 188 (339 BGL-IU/g) & $85 \%$ & $\begin{array}{l}2.5-\mathrm{L} \\
\text { bioreactor }\end{array}$ & Bertilsson et al. (2009) \\
\hline & & & & $\begin{array}{l}\text { ATAEA ( } 30 \mathrm{FPU} / \mathrm{g} \text { total glucan and } \\
60 \mathrm{BGL}-\mathrm{IU} / \mathrm{g} \text { total glucan) }\end{array}$ & & & \\
\hline \multirow{3}{*}{$\operatorname{SSF}^{\mathbf{h}}$} & \multirow{3}{*}{ S. cerevisiae } & \multirow{3}{*}{$\begin{array}{l}\text { Salix chips } \\
\text { (WIS content of 9\%) }\end{array}$} & \multirow[t]{2}{*}{$\begin{array}{l}\text { Acid } \\
\left(2 \% \mathrm{SO}_{2}, 205^{\circ} \mathrm{C}, 5 \mathrm{~min}\right)\end{array}$} & $\begin{array}{l}\text { Celluclast } 1.5 \mathrm{~L} \text { ( } 65 \text { FPU/g and } 17 \\
\text { BGL-IU/g) }\end{array}$ & & & \\
\hline & & & & Novozym 188 (376 BGL-IU/g) & $76 \%$ & $\begin{array}{l}\text { 4-L } \\
\text { bioreactor }\end{array}$ & Sassner et al. (2006) \\
\hline & & & Steam $\left(210^{\circ} \mathrm{C}, 14 \mathrm{~min}\right)$ & $\begin{array}{l}\text { ATAEA ( } 15 \text { FPU/g WIS and } 23 \\
\text { BGL-IU/g WIS) }\end{array}$ & & & \\
\hline \multirow{2}{*}{ SSF } & & \multirow{2}{*}{$\begin{array}{l}\text { Rice straw } \\
\text { (WIS content of 5\%) }\end{array}$} & $\begin{array}{l}\text { Dilute-acid } \\
\left(0.5 \% \mathrm{H}_{2} \mathrm{SO}_{4}, 20 \mathrm{~h}\right)\end{array}$ & $\begin{array}{l}\text { BTXL ( } 55 \mathrm{FPU} / \mathrm{mL} \text { and } 112 \text { BGL- } \\
\mathrm{IU} / \mathrm{mL} \text { ) }\end{array}$ & $68-74 \%$ & $10-\mathrm{L}$ & Karimi et al (2006) \\
\hline & Rhizopus oryzae & & Steam (1.5 min, $1.5 \mathrm{MPa})$ & $\begin{array}{l}\text { ATAEA ( } 15 \text { FPU/g cellulose and } 50 \\
\text { BGL-IU/g WIS) }\end{array}$ & & bioreactor & \\
\hline \multirow{3}{*}{ SSF } & \multirow{3}{*}{$\begin{array}{l}\text { S. cerevisiae/ } \\
\text { Kluyveromyces } \\
\text { marxianus Y01070 }\end{array}$} & $\begin{array}{l}\text { Solka Floc } \\
\text { (WIS content of } 6 \% \text { ) }\end{array}$ & \multirow{3}{*}{$\mathrm{NA}^{\mathrm{i}}$} & $\begin{array}{l}\text { Celluclast } \\
1.51(75.8 \mathrm{FPU} / \mathrm{mL} \text { and } 38.5 \mathrm{BGL}- \\
\mathrm{IU} / \mathrm{mL})\end{array}$ & $56-61 \%$ & \multirow{3}{*}{ E-flask } & \multirow{3}{*}{ Kádár et al. (2004) } \\
\hline & & $\begin{array}{l}\mathrm{OCC}^{\mathbf{j}} \\
\text { (WIS content of } 6 \% \text { ) }\end{array}$ & & $\begin{array}{l}\text { Iogen Cellulase }(99.8 \mathrm{FPU} / \mathrm{mL} \text { and } \\
114.9 \mathrm{BGL}-\mathrm{IU} / \mathrm{mL})\end{array}$ & $55-56 \%$ & & \\
\hline & & $\begin{array}{l}\text { Paper sludge } \\
\text { (WIS content of } 6 \% \text { ) }\end{array}$ & & $\begin{array}{l}\text { Novozym } 188 \text { (421 BGL-IU/mL) } \\
\text { ATAEA (15 FPU/g WIS and } \\
15 \text { BGL-IU/g per g WIS) }\end{array}$ & $58-60 \%$ & & \\
\hline $\mathrm{SHF}^{\mathbf{k}}$ & S. cerevisiae GIM-2 & Paper sludge & NA & $\begin{array}{l}\text { Novozym } 342 \text { (50 FPU/mL) } \\
\text { ATAEA (18.1 FPU/g substrate) }\end{array}$ & $56.3 \%$ & Flask & Peng and Chen (2011) \\
\hline \multirow[t]{2}{*}{ SHF } & \multirow{2}{*}{$\begin{array}{l}\text { M. indicus/ } \\
\text { R. oryzael } \\
\text { S. cerevisiae }\end{array}$} & \multirow[t]{2}{*}{ Rice straw } & \multirow{2}{*}{$\begin{array}{l}\text { Dilute acid } \\
\left(0.5 \% \mathrm{H}_{2} \mathrm{SO}_{4}, 20 \mathrm{~h}\right) \\
\text { Steam }(1.5 \mathrm{~min}, 1.5 \mathrm{MPa})\end{array}$} & $\begin{array}{l}\text { BTXL ( } 55 \text { FPU/mL) } \\
\text { Novozym } 188 \text { (608 BGL-IU/mL) }\end{array}$ & \multirow[t]{2}{*}{$\begin{array}{l}0.33-0.45 \\
\mathrm{~g} / \mathrm{g}\end{array}$} & \multirow[t]{2}{*}{ Flask } & \multirow[t]{2}{*}{ Abedinifar et al. (2009) } \\
\hline & & & & $\begin{array}{l}\text { ATAEA ( } 15 \mathrm{FPU} / \mathrm{g} \text { cellulose and } 50 \\
\text { BGL-IU/g WIS) }\end{array}$ & & & \\
\hline \multirow{3}{*}{ SHF } & & & & Commercial cellulase (6.5 FPU/mg) & & & \\
\hline & $\begin{array}{l}\text { Pichia stipites/ } \\
\text { S. cerevisiae }\end{array}$ & $\begin{array}{l}\text { Prosopis juliflora } \\
\text { (Mesquite) }\end{array}$ & $\begin{array}{l}\text { Dilute acid } \\
\left(3 \% \mathrm{H}_{2} \mathrm{SO}_{4}, 120^{\circ} \mathrm{C}, 1 \mathrm{~h}\right)\end{array}$ & $\begin{array}{l}\beta \text {-glucosidase (Novozyme 188) } \\
(250 \text { BGL-IU/g) }\end{array}$ & $\begin{array}{l}0.39-0.49 \\
\mathrm{~g} / \mathrm{g}\end{array}$ & $\begin{array}{l}\text { 13.5-L } \\
\text { fermenter }\end{array}$ & Gupta et al. (2009) \\
\hline & & & & $\begin{array}{l}\text { ATAEA ( } 3 \text { FPU/mL and } 9 \text { BGL- } \\
\text { IU/mL of citrate phosphate buffer) }\end{array}$ & & & \\
\hline
\end{tabular}

${ }^{\text {a }}$ Simultaneous saccharification and co-fermentation

b Water insoluble solids

c All acid concentrations are based on $\mathrm{v} / \mathrm{v}$

${ }^{\text {d }}$ Filter paper unit (cellulase activity)

e $\beta$-glucosidase international unit activity

${ }^{f}$ Process development unit

Activities of total amount of enzyme added

h Simultaneous saccharification and fermentation

${ }^{i}$ Not available

$\mathbf{j}$ Old corrugated cardboard

${ }^{\mathbf{k}}$ Separate hydrolysis and fermentation 


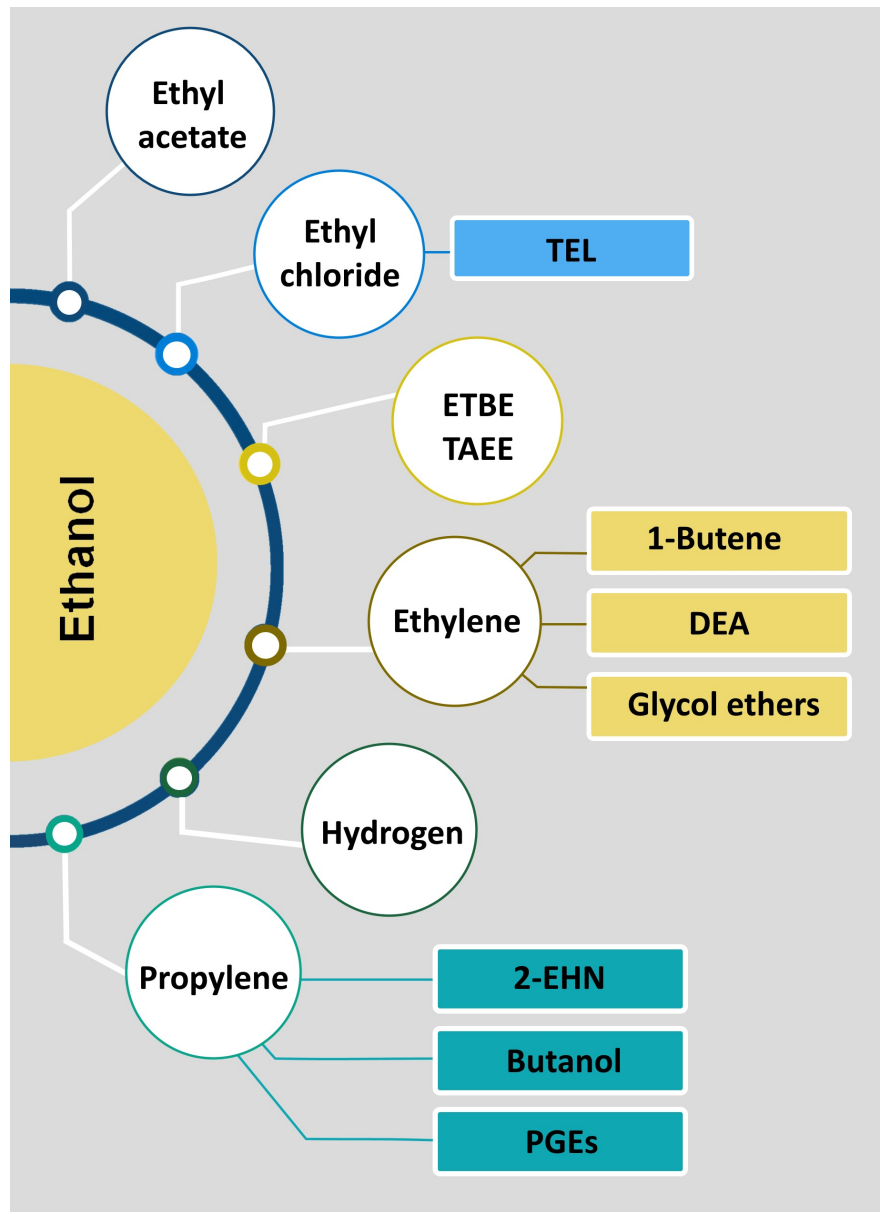

Fig. 3. Ethanol-derived chemicals with fuel and fuel additive properties; with optimal processing conditions and catalyst use, ethanol can be converted to chemicals that range from ethylene to butanol. 2EHN, 2-ethylhexyl nitrate; DEGEE, diethylene glycol ethyl ether; EGEE monoethylene glycol ethyl ether; ETBE, ethyl tert-butyl ether; PGE, propyl glycerol ether; TAEE, tert-amyl ethyl ether; and TEL, tetraethyl-lead.

\section{Butanol}

\subsection{Background and possibilities}

Butanol is a colorless four-carbon alcohol with a characteristic bananalike odor. The high energy content of butanol, its hydrophobicity and flash point, make it a potential substitute for gasoline and diesel as fuel sources. The other desirable qualities of this C4-liquid energy source includes: low volatility, miscibility, and octane-enhancement property (Schwarz and Gapes, 2006). The relatively greater heat of evaporation for butanol results in a lesser combustion temperature and reduced $\mathrm{NO}_{\mathrm{X}}$ emissions relative to many other energy sources (Rakopoulos et al., 2010). The branched forms (isomers) of butanol such as 2-methyl-1-butanol, 3-methyl-1-butanol, and isobutanol also have high octane numbers and desirable fuel and fuel additive properties (Atsumi et al., 2008b). The fuel properties of butanol isomers are provided in Table 7, some of which are superior to that of ethanol (Table 3), methanol (Table 2), or gasoline (Table 1).

A major limiting factor for the use of biobutanol as biofuel, however, is its low concentration in the bioreactor during acetone butanol ethanol (ABE) fermentation, which is 8 to 18 times less than that of ethano produced by yeast fermentation. The low butanol concentration in the fermentation broth upon completion of ABE fermentation is due to butanol toxicity to the fermenting microbes at low concentrations $(<1.5 \%)$. This impediment is probably the major reason why ethanol is still the liquid biofuel that continues to be most commercially available. Advances in metabolic engineering techniques have pushed commercialization of the fermentative production of butanol. However, further research in the areas of non-food substrates application, process optimization, and product recovery are still needed to sustain current commercialization efforts (Greene, 2004; Meadows et al., 2018). Butanol produced from fossil fuels and gases is presently commercially available as a solvent and for the production of butyl acrylate which is a primary chemical feedstock used for the production of water-based paints.

\subsection{Chemical synthesis of butanol}

Crotonaldehyde hydrogenation, oxo synthesis (hydroformylation), and Reppe synthesis (Fig. 4) are the three major chemical processes for butanol synthesis. Prior to 1950s, crotonaldehyde hydrogenation of acetaldehyde to butanol was the common production process. The crotonaldehyde hydrogenation process involves an aldo condensation of acetaldehyde at ambient temperatures and pressure in the presence of alkaline catalysts, which is followed by dehydration as a result of acidification with AA or

Table 7.

Properties of butanol isomers.

\begin{tabular}{|c|c|c|c|c|}
\hline Parameter & 1-butanol & 2-butanol & tert-butyl alcohol & Isobutanol \\
\hline Chemical formula & $\mathrm{C}_{4} \mathrm{H}_{10} \mathrm{O}$ & $\mathrm{C}_{4} \mathrm{H}_{10} \mathrm{O}$ & $\mathrm{C}_{4} \mathrm{H}_{10} \mathrm{O}$ & $\mathrm{C}_{4} \mathrm{H}_{10} \mathrm{O}$ \\
\hline Structure & & & $\mathrm{H}_{3} \mathrm{C} \overbrace{\mathrm{CH}_{3}}^{\mathrm{OH}}$ & $\mathrm{H}_{3} \mathrm{C}$ \\
\hline Boiling point $\left({ }^{\circ} \mathrm{C}\right)$ & 117.7 & 99.5 & 82.4 & 108 \\
\hline Melting point $\left({ }^{\circ} \mathrm{C}\right)$ & -89.8 & -114.7 & 25.4 & -108 \\
\hline Flash point $\left({ }^{\circ} \mathrm{C}\right)$ & 28.89 & 24 & 11 & 28 \\
\hline Viscosity (mPa s) & 2.544 & 3.096 & - & 4.312 \\
\hline Density $\left(\mathrm{kg} / \mathrm{m}^{3}\right)$ & 809.8 & 806.3 & 788.7 & 801.8 \\
\hline Flammability limits, vol.\% & $1.4-11.2$ & $1.7-9.6$ & $2.4-8$ & $1.2-10.9$ \\
\hline Ignition temperature $\left({ }^{\circ} \mathrm{C}\right)$ & 343 & 406.1 & 477.8 & 415.6 \\
\hline Vapor pressure (mmHg) & 7 & 18.3 & 40.7 & 10.4 \\
\hline Motor octane No. & 78 & 32 & 89 & 94 \\
\hline Research octane No. & 96 & 101 & 105 & 113 \\
\hline Calorific value (MJ/kg) & 36.1 & $-360 \times 10^{+5}$ & - & 36 \\
\hline
\end{tabular}

Please cite this article as: Kazemi Shariat Panahi H., Dehhaghi M., Kinder J.E., Ezeji T.C. A review on green liquid fuels for the transportation sector: a prospect of microbial solutions to climate change. Biofuel Research Journal 23 (2019) 995-1024. DOI: 10.18331/BRJ2019.6.3.2 
a)

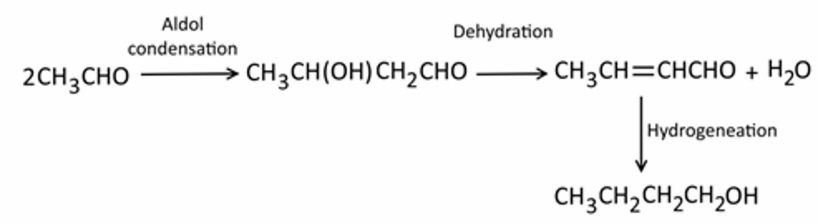

b)

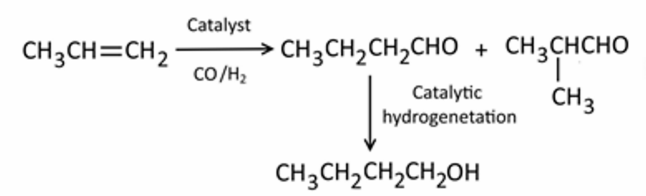

c)

$$
\mathrm{CH}_{3} \mathrm{CH}=\mathrm{CH}_{2} \underset{\mathrm{CO} / \mathrm{H}_{2} \mathrm{O}}{\stackrel{\text { Catalyst }}{\longrightarrow}} \mathrm{CH}_{3} \mathrm{CH}_{2} \mathrm{CH}_{2} \mathrm{CH}_{2} \mathrm{OH}+\underset{\mathrm{CH}_{3}}{\mathrm{CH}_{3}} \underset{\mathrm{CHCH}_{2} \mathrm{OH}}{\mathrm{CH}_{3}}+2 \mathrm{CO}_{2}
$$

Fig. 4. Chemical synthesis of butanol using the three major processes: (a) crotonaldehyde, (b) oxo synthesis, and (c) Reppe synthesis.

$\mathrm{H}_{3} \mathrm{PO}_{4}$. The resulting compound, crotonaldehyde, is distillated followed by hydrogenation at the gaseous or liquid phases in the presence of a $\mathrm{Cu}$ catalyst. Compared to hydroformylation and Reppe synthesis, crotonaldehyde hydrogenation does have complete reliance for a petroleum feedstock although biomass-derived ethanol can be used as feedstock. Thus, ethanol can be dehydrogenated into acetaldehyde as the starting feedstock for the crotonaldehyde hydrogenation process for butanol synthesis (Cotton et al., 1999; Lee et al., 2008; Uyttebroek et al., 2015). The invention of the oxo synthesis process, a variation of Fischer-Tropsch (FT) process of Ruhrchemie's Roelen, led to the demise of the use of the crotonaldehyde hydrogenation process because the oxo process is economically less expensive and more efficient from a productive perspective. The first step of oxo process of chemical butanol synthesis is the reaction between petroleum-derived olefins such as $\mathrm{C}_{2} \mathrm{H}_{4}$ and propylene $\left(\mathrm{C}_{3} \mathrm{H}_{6}\right)$ and carbon monoxide $(\mathrm{CO})$ in the presence of $\mathrm{Rh}$ or Ru catalyst for the production of intermediate compounds (aldehydes) with a formyl group $(\mathrm{CHO})$. The generated aldehydes have one more $\mathrm{C}$ atom than the starter compound, i.e., olefin. This process can be energy consuming as it is conducted at high temperatures $\left(80-200{ }^{\circ} \mathrm{C}\right)$ and pressures $(20-30 \mathrm{MPa})$ depending on the type of catalyst used. Following the production of the aldehyde mixture (1-butanal and 2-methylpropanal) in the first step of the reaction, the second step involves hydrogenation of the aldehydes in liquid or vapor phase using $\mathrm{Cu}, \mathrm{Ni}$, or the combination of the two to the corresponding alcohols (25\% 2-methyl-1-propanol or isobutanol and 75\% 1-butanol) (O'rourke et al., 1981).

The leading producers of butanol using this process are BASF, Dow Chemical Company, and Oxea Group (Uyttebroek et al., 2015). Furthermore, the Reppe process was developed in 1942 and involves carbonylation of $\mathrm{C}_{3} \mathrm{H}_{6}$ using $\mathrm{CO}$ and $\mathrm{H}_{2} \mathrm{O}$ with inclusion of a catalyst (tertiary ammonium salt or polynuclear iron carbonyl hydrides) at 0.5 to $2 \mathrm{MPa}$ and $100{ }^{\circ} \mathrm{C}$ to produce 1 butanol (Cotton et al., 1999; Uyttebroek et al., 2015). During the process, 1butanol and isobutanol are directly generated in a ratio of 43:7. Even though Reppe process has relatively moderate reaction conditions and generates greater yield of 1-butanol than with the oxo process, the Reppe process has not been commercially implemented because the process is economically impractical.

\subsection{Butanol-producing microorganisms}

Solventogenic Clostridium is best known for natural capacity to produce butanol (Lee et al., 2008; Ujor et al., 2016; Xin et al., 2018). Approximately 40 solventogenic Clostridium strains are available in public culture collections, an enormous pool of strains and resource for screening novel traits such as solventogenic Clostridium strains are available in public culture collections, an enormous pool of strains and resource for screening novel traits such as utilization of alternative substrates for butanol production, phage resistance, and hyper solvent-producing capacity (Zverlov et al., 2006). It is worth noting that with use of these strains, a combination of solvents, often including acetone, butanol, and ethanol could be produced Clostridium acetobutylicum ATCC 824 and Clostridium beijerincki NCIMB 8052 are the most studied solventogenic Clostridium species. Clostridium saccharobutylicum and Clostridium saccharoperbutylacetonium have been receiving attention recently for the production of large amounts of butanol during ABE fermentation (Dürre, 2005; Dong et al., 2018; Huang et al., 2018; Foulquier et al., 2019). Clostridium species such as Clostridium ljungdahlii and Clostridium butyricum have the capacity to utilize syngas and hemicellulose, respectively, for acetone and butanol production (Montoya et al., 2001). Through metabolic engineering, aerobic and/or facultative microorganisms such as Bacillus subtilis, E. coli, S. cerevisiae, and Bacillus sp., 15 have been developed to produce large amounts of solvents (Atsumi et al., 2008a, 2008b; Inui et al., 2008). Indeed, with use of Bacillus sp. 15, large amounts of butanol $(12.3 \mathrm{~g} / \mathrm{L})$, acetone $(5.05 \mathrm{~g} / \mathrm{L})$ and ethanol $(0.115 \mathrm{~g} / \mathrm{L})$ titers $(\mathrm{Ng}$ et al., 2016) could be produced comparable to those of solventogenic Clostridium species. While this research has not been replicated by an independent laboratory, the quest appears to be feasible for the development of a suitable aerobic platform for the production of butanol. Meanwhile, the cost of butanol recovery from fermentation broth is the second largest contributor to biobutanol production cost (about 16\%), the first being substrate cost, due to the formation of mixed solvents and the low butanol titer in $\mathrm{ABE}$ fermentation.

\subsubsection{Butanol fermentation: challenges}

The lack of butanol tolerance by fermenting microorganisms has been identified as the major factor that causes the lesser cell density and premature termination of fermentation during butanol production by solventogenic Clostridium microbes. To mitigate this problem, severa strategies such as metabolic engineering of microorganisms for improved butanol tolerance and production, and in-situ real-time butanol recovery to reduce solvent toxicity to the microorganisms and enhance butanol production have been proposed (Annous and Blaschek, 1991; Green et al., 1996; Harris et al., 2001; Tomas et al., 2003; Lee et al., 2008; Ezeji et al. 2010).

\subsubsection{Metabolic engineering of fermenting microorganisms}

Genetic improvements of ABE-producing strains generally include one of two approaches: (i) enhancement of $\mathrm{ABE}$ tolerance in solventogenic Clostridium spp. and (ii) metabolic engineering of well-characterized microorganisms such as E. coli and S. cerevisiae for ABE production (Ezeji et al., 2010). The overarching objective of these methods is to produce greater titers of butanol during fermentation. Notably, increasing the concentration of butanol from 10 to $40 \mathrm{~g} / \mathrm{L}$ results in a 6 -fold decrease in the amount of oil (energy) required to recover butanol from fermentation broth. Genetic strain improvement of solventogenic clostridia such as $C$. acetobutylicum and $C$. beijerinckii for greater solvent tolerance, production, and yield, and development of non-native butanol producing microorganisms as platforms for producing butanol are included in Table 8. Although native butanol producing solventogenic Clostridium microbes have some inherent advantages such as capacity to utilize a wide range of substrates and production of multiple products, there are also some inherent limitations of these microbes such as their obligate anaerobic nature, slow growth rates, and less tractability in terms of genetic engineering when compared to well-characterized microorganisms such as E. coli, B. subtilis, and $S$. cerevisiae. Development of well-characterized microorganisms such as E. coli and S. cerevisiae, therefore, as viable platforms for butanol production are being considered (Ezeji et al., 2010). Recently, microorganisms that have a natural capacity to tolerate relatively greater concentrations of butanol than the native butanol producers have been considered as viable platform for producing butanol (Table 8 , section $c$ ). 
Table 8.

Amelioration of solvent toxicity in acetone- and butanol-producing microorganisms with genetic strain improvements.

\begin{tabular}{|c|c|c|c|c|}
\hline Mutated Strain & Strain used for mutation & Method & Achievements & Reference \\
\hline \multicolumn{5}{|c|}{ a. Strategy: Enhancing $A B E^{\text {a }}$ resistance in solventogenic clostridia } \\
\hline SA-1 & \multirow{2}{*}{$\begin{array}{l}\text { Clostridium acetobutylicum } \\
\text { ATCC } 824\end{array}$} & \multirow{2}{*}{$\begin{array}{l}\text { Serial transfer into fresh media with increasing } \\
\text { concentrations of 1-butanol. }\end{array}$} & $\begin{array}{l}\text {-Higher butanol tolerance }(121 \%) \\
\text {-No increase in butanol yield }\end{array}$ & Lin and Blaschek (1983) \\
\hline SA-2 & & & $\begin{array}{l}\text {-Higher butanol tolerance ( } 27 \%) \\
\text {-No increase in butanol yield }\end{array}$ & Baer et al. (1987) \\
\hline PJC4BK & C. acetobutylicum ATCC 824 & Inactivation of butyrate kinase & $\begin{array}{l}\text {-Higher butanol production }(28 \%) \\
\text {-Enhance solvent tolerance }\end{array}$ & Green et al. (1996) \\
\hline SolRH & C. acetobutylicum ATCC 824 & Inactivation of solvent formation repressor solR & $\begin{array}{l}\text { Higher ABE production }(25 \%, 14 \% \text {, and } 81 \% \text {, } \\
\text { respectively, for butanol, acetone, and ethanol) }\end{array}$ & $\begin{array}{l}\text { Nair et al. (1999) } \\
\text { Harris et al. (2001) }\end{array}$ \\
\hline $\begin{array}{l}\text { SolRH } \\
\text { (pTAAD) }\end{array}$ & $\begin{array}{l}\text { C. acetobutylicum strain } \\
\text { SolRH }\end{array}$ & Overexpression of the alcohol dehydrogenase gene aad & $\begin{array}{l}\text {-Higher ABE production }(21 \%, 45 \% \text {, and } 62 \% \text {, } \\
\text { respectively, for butanol, acetone, and ethanol) } \\
\text {-Produced } 17.6 \text { and } 8.2 \mathrm{~g} / \mathrm{L} \text { butanol and acetone, } \\
\text { respectively }\end{array}$ & Harris et al. (2001) \\
\hline pGROE1 & C. acetobutylicum ATCC 824 & $\begin{array}{l}\text { Overexpressing of genes in the class I stress } \\
\text { response operon groESL }\end{array}$ & $\begin{array}{l}\text {-Less growth inhibition from butanol }(85 \%) \\
\text { Production of } 17.1 \mathrm{~g} / \mathrm{L} \text { butanol and } 8.6 \mathrm{~g} / \mathrm{L} \text { acetone. } \\
\text {-Longer active metabolism } \\
\text {-Increased expression of motility and chemotaxis } \\
\text { genes } \\
\text {-Decreased expression of main stress response genes }\end{array}$ & Tomas et al. (2003) \\
\hline $\begin{array}{l}\text { pCAC0003 and } \\
\text { pCAC } 1869\end{array}$ & C. acetobutylicum ATCC 824 & $\begin{array}{l}\text { Genomic library } \\
\text { Plasmids were inserted into wild type } C \text {. acetobutylicum } \\
\text { cells via electroporation, and the cells were challenged } \\
\text { with various } \\
\text { amounts of butanol }\end{array}$ & $\begin{array}{l}\text { Sixteen genes were identified as contributing to the } \\
\text { cells } \\
\text { ability to withstand greater concentrations of butanol } \\
\text { pCAC } 0003 \text { and pCAC1869 showed a } 24 \% \text { - and } \\
45 \% \text { - increase in tolerance }\end{array}$ & $\begin{array}{l}\text { Borden and Papoutsakis } \\
(2007)\end{array}$ \\
\hline BA101 & $\begin{array}{l}\text { Clostridium beijerinckii } \\
\text { NCIMB } 8052\end{array}$ & $\begin{array}{l}\text { Direct mutation with N-methyl-N-nitro-N- } \\
\text { nitrosoguanidine }\end{array}$ & $\begin{array}{l}\text {-Higher solvent production than any } C \text {. } \\
\text { acetobutylicum } \\
\text { strain engineered at that time } \\
\text {-Good stability } \\
\text {-Hyper-amylolytic and hyper-butanologenic (up to } 19 \\
\text { g/L) characteristics } \\
\text {-Total solvent concentration of } 29 \mathrm{~g} / \mathrm{L} \\
\text {-Higher butanol production }(2 \times) \text { and threshold }(2.1 \times) \\
\text { than wild type strain }\end{array}$ & $\begin{array}{l}\text { Annous and Blaschek } \\
(1991) \\
\text { Qureshi and Blaschek } \\
(2001)\end{array}$ \\
\hline
\end{tabular}

b. Strategy: Metabolic engineering of well-characterized microorganisms

\begin{tabular}{|c|c|c|c|c|}
\hline $\begin{array}{l}\text { ATCC } 11303 \\
(\mathrm{pACT})\end{array}$ & Escherichia coli & $\begin{array}{l}\text { Expression of four C. acetobutylicum } \\
\text { ATCC } 824 \text { genes (adc, ctfA, ctfB, and } t h l)\end{array}$ & $\begin{array}{l}\text { Higher acetone production }(5.4 \mathrm{~g} / \mathrm{L}) \text { comparable to } \\
\text { wild type } C \text {. acetobutylicum }\end{array}$ & Bermejo et al. (1998) \\
\hline
\end{tabular}

\begin{tabular}{|c|c|c|c|c|}
\hline JCL16 & E. coli & $\begin{array}{l}\text {-Overexpression of KDCs }{ }^{\mathbf{b}} \text { and ADHs } \\
\text {-Metabolic engineering of amino acid biosynthetic } \\
\text { pathway to enhance the production of the specific 2-keto } \\
\text { acid for improvement of desired alcohol production } \\
\text {-Deletion of genes corresponding to competing reactions } \\
\text {-Replacement of some native E. coli genes with more } \\
\text { active genes from other hosts }\end{array}$ & $\begin{array}{l}\text {-High-yield, and high-specificity production of } \\
\text { isobutanol }(22 \mathrm{~g} / \mathrm{L}) \text { from glucose }\end{array}$ & Atsumi et al. (2008b) \\
\hline $\mathrm{NA}^{\mathbf{d}}$ & Saccharomyces cerevisiae ${ }^{\mathbf{e}}$ & $\begin{array}{l}\text { Cloning the 1-butanol pathway and various isozymes } \\
\text { selected from C. beijerinckii }\end{array}$ & Production of $2.5 \mathrm{mg} / \mathrm{L}$ of 1-butanol & Steen et al. (2008) \\
\hline \multicolumn{5}{|c|}{ c. Strategy: Solvent-resistant microorganisms as potential acetone-butanol production hosts } \\
\hline $\mathrm{S} 12$ & Pseudomonas putida & Adaptation by serial transfer & Capable of growth on $6 \%$ butanol & Rühl et al. (2009) \\
\hline $\begin{array}{l}\text { PS1.0 } \\
\text { PS2.0 }\end{array}$ & P. putida strain $\mathrm{S} 12$ & Polycistronic expression of butanol biosynthetic genes & $\begin{array}{l}\text {-Production of } 44 \text { and } 50 \mathrm{mg} / \mathrm{L} \text { butanol, respectively, } \\
\text { when grown on glucose } \\
\text {-Production of } 122 \text { and } 112 \mathrm{mg} / \mathrm{L} \text { butanol, } \\
\text { respectively, when grown on glycerol. } \\
\text {-Capable of growth on } 6 \% \text { butanol }\end{array}$ & $\begin{array}{l}\text { Nielsen et al. (2009) } \\
\text { Rühl et al. (2009) }\end{array}$ \\
\hline
\end{tabular}

acetone, butanol, ethanol

$\mathbf{b}_{2 \text {-keto-acid decarboxylase }}$

c Alcohol dehydrogenase

${ }^{\text {d }}$ Not available

${ }^{\mathbf{e}}$ Can be also considered as solvent-resistant microorganisms 
Table 9.

Summary of techniques for simultaneous in situ recovery of butanol during fermentation.

\begin{tabular}{|c|c|c|c|c|c|}
\hline Technique & Extraction process & Recovery process & Achievements a & Limitations & Reference \\
\hline Gas stripping & $\begin{array}{l}\text { Sparging } \mathrm{O}_{2} \text {-free nitrogen or fermentation } \\
\text { gases }\left(\mathrm{CO}_{2} \text { and } \mathrm{H}_{2}\right) \text { through the } \\
\text { fermentation broth }\end{array}$ & $\begin{array}{l}\text { Enriched gas (or gases) with } \mathrm{ABE}^{\mathbf{b}} \\
\text { are cooled in a condenser to recover } \\
\text { ABE, then absorbent gases are } \\
\text { recycles }\end{array}$ & $\begin{array}{l}\text {-Increases productivity } \\
\text {-Increases yield } \\
\text {-Relieves toxicity }\end{array}$ & Low butanol stripping rate & $\begin{array}{l}\text { Qureshi et al. (1992) } \\
\text { Ezeji et al. (2010) }\end{array}$ \\
\hline $\begin{array}{l}\text { Liquid-liquid } \\
\text { extraction }\end{array}$ & $\begin{array}{l}\text { Butanol is extracted by organic (extractant) } \\
\text { solvent such as oleyl alcohols and dibutyl } \\
\text { phthalate }\end{array}$ & $\begin{array}{l}\text { ABE solvents are recovered by back } \\
\text { extraction into another organic } \\
\text { solvent or by distillation. }\end{array}$ & $\begin{array}{l}\text {-Increases productivity } \\
\text {-Relieves toxicity }\end{array}$ & $\begin{array}{l}\text {-Extractant toxicity to cells } \\
\text {-Formation of rag layer and } \\
\text { emulsion } \\
\text {-Loss of fermentation intermediate } \\
\text { products }\end{array}$ & Ezeji et al. (2010) \\
\hline Perstraction & $\begin{array}{l}\text { Membrane contactor in perstraction process } \\
\text { provides surface area where the two } \\
\text { immiscible phases can exchange the butanol }\end{array}$ & $\begin{array}{l}\text { Butanol is diffused across the } \\
\text { membrane }\end{array}$ & $\begin{array}{l}\text {-Increases productivity } \\
\text {-Relieves toxicity }\end{array}$ & $\begin{array}{l}\text {-Low butanol extraction rate due to } \\
\text { membrane fouling } \\
\text {-Loss of fermentation intermediate } \\
\text { product } \\
\text {-Expensive and complicated to } \\
\text { operate }\end{array}$ & $\begin{array}{l}\text { Qureshi et al. (1992) } \\
\text { Ezeji et al. (2010) }\end{array}$ \\
\hline Pervaporation & $\begin{array}{l}\text { ABE solvents are selectively adsorbed onto } \\
\text { surface of either hydrophilic or hydrophobic } \\
\text { membranes such as PDMS }{ }^{\mathbf{c}} \text {, PTMSP }{ }^{\mathbf{d}} \text {, and } \\
\text { composite membrane; and diffused through } \\
\text { them }\end{array}$ & $\begin{array}{l}\text { Dissolved solvents absorbed into } \\
\text { permeate evaporate at the } \\
\text { downstream surface of membrane }\end{array}$ & $\begin{array}{l}\text {-Increases productivity } \\
\text {-Relieves toxicity }\end{array}$ & $\begin{array}{l}\text {-Loss of fermentation intermediate } \\
\text { products due to diffusion across } \\
\text { membrane } \\
\text {-Membrane fouling }\end{array}$ & $\begin{array}{l}\text { Qureshi et al. (1992) } \\
\text { Vane (2005) } \\
\text { Shao and Huang (2007) } \\
\text { Ezeji et al. (2010) }\end{array}$ \\
\hline
\end{tabular}

${ }^{\mathrm{a}}$ In regard of butanol

${ }^{\text {b }}$ Acetone, butanol, and ethanol

c Polydimethylsiloxane

${ }^{\text {d }}$ Poly(1-trimethylsilyl-1-propyne)

\subsubsection{Simultaneous $A B E$ fermentation and product recovery systems}

Advanced fermentation technologies and downstream processing may be applied to overcome the low solvent tolerance of native or engineered ABEproducing microorganisms. A number of different in-situ recovery methods including adsorption, gas stripping, liquid-liquid extraction, perstraction, pervaporation, and reverse osmosis has been investigated for decreasing butanol microbial intolerance during ABE fermentation (Vane, 2005; Shao and Huang, 2007; Ezeji, 2010; Jiménez-Bonilla and Wang, 2018; Naidoo et al., 2018; Raganati et al., 2018; Azimi et al., 2019; Zhu et al., 2019). These realtime processes for removing butanol from the bioreactor during $\mathrm{ABE}$ fermentation have limitations that range from loss of nutrients to adsorbent, clogging, loss of fermentation (acetic and butyric acids) intermediates, and compatibility with utilization of only clean/pure substrates such as glucose and sucrose, thus, excluding the capacity for use of lignocellulosic biomass hydrolysates. Consequently, Ezeji's group at the Ohio State University, USA, have been developing a non-sparger, non-membrane-based vacuum-assisted gas stripping technology (VGST). Initial assessments indicated a 10-fold enhanced efficiency for real-time butanol recovery during fermentation compared to traditional gas stripping processes (Mariano et al., 2011; Mariano et al., 2012). With the VGST process, the fermentation is conducted at a reduced pressure in the bioreactor, causing butanol to boil off at the fermentation temperature (Mariano et al., 2012). It should be noted that the VGST process is compatible with the fermentation of impure fibrous or colloidal substrates as there are no problems with clogging or fouling. Even though there have been advances in these technologies, there is no known commercial application of any of these advanced fermentation technologies. In addition to the limitations highlighted in Table 9, the energy requirement for operating these advanced fermentation systems that enable simultaneous fermentation and in situ product recovery may be cost prohibitive, thus, impeding the commercialization of these processes.

4.4. Butanol derivatives as fuel additives: production, applications, and performance

Even though there is great potential of butanol as an automobile fuel, it has limited application as a high-performance military fuel. This is mainly because of the $\mathrm{O}_{2}$ content of butanol, which limits its net heat of combustion as well as relatively low flashpoint. To improve the fuel characteristics of butanol in this regard, a fully saturated fuel mixture can be produced through oligomerization of a derivative of butanol such as 1-butene, a linear alpha olefin, which can be generated with dehydration of butanol. Ethanol or methanol can also serve as a feedstock for the production of 1-butene by inducing $\mathrm{C}_{2} \mathrm{H}_{4}$ dimerization using Alphabutol process, which uses a metallacyclic mechanism involving titanium butoxide/triethylaluminium $\left[\mathrm{Ti}(\mathrm{OBu}) 4 / \mathrm{AlEt}_{3}\right]$ or zirconium alkoxides with optimal selectivity of about 93\% (McGuinness, 2011). Following distillation, 1-butene or its derivatives such as polyethylene or polypropylene can be used as fuel or as a fuel additive. Wright et al. (2008) produced a new jet fuel by subjecting 1butene and oligomers to a hydrogenation process in the presence of platinum oxides $\left(\mathrm{PtO}_{2}\right)$ at $0.01 \mathrm{MPa}$. The final product was a fully saturated fuel mixture $\left(\mathrm{C}_{12}-\mathrm{C}_{16}\right.$ oligomers $)$ with a flash point, viscosity and lubricity values of $59^{\circ} \mathrm{C}, 103 \mathrm{cSt}$, and $0.45 \mathrm{~mm}$, respectively.

Similar to FAME, fatty acid butyl esters (FABE) are produced after reactions between vegetable oils containing fatty acid esters and butanol in the presence of a catalyst (Tabatabaei et al., 2019a). This biodiesel, which decreases the emission of $\mathrm{HCs}$ and $\mathrm{NO}_{\mathrm{x}}$ as well as smoke production by diesel engines, can be blended with diesel without a change in performance. For example, combining esterified soybean and sunflower seed oils with butanol have resulted in a satisfactory performance and reduction in emissions when blended with diesel at $20 \%$ and used as fuel (Singh and Anbumani, 2011). Furthermore, biodiesel esters (i.e., butyl and methyl) have been produced and characterized from Afzelia africana, Cucirbita pepo, and Hura crepitans seed oils (Ogbu and Ajiwe, 2016).

Two gasoline octane enhancement compounds, i.e., $n$-butyl acetate and $n$-butyl acrylate have been respectively produced at industrial scales through esterification of $n$-butanol with AA in the presence of a suitable acid catalyst and the reaction of acrylic acid and $n$-butanol using strong acidic homogeneous catalysts. The treatment of butanol with $\mathrm{H}_{2} \mathrm{SO}_{4}$ or its catalytic dehydration in the presence of aluminosilicate $\left(\mathrm{Al}_{2} \mathrm{O}_{5} \mathrm{Si}\right)$, ferric chloride $\left(\mathrm{FeCl}_{3}\right)$, or copper sulfate $\left(\mathrm{CuSO}_{4}\right)$ at elevated temperatures is commonly used for the production of dibutyl ether (DBE), a diesel cetane oxygenate that improves self-ignition (Karas and Piel, 2005; Arteconi et al., 2011). Gómez Cuenca et al. (2011) reported that monoethylene glycol butyl ether (EGBE), a glycol ether, decreases cetane number and emissions (CO, $\mathrm{HC}, \mathrm{NO}_{\mathrm{x}}$ ); whereas improves fuel lubricity and viscosity when 


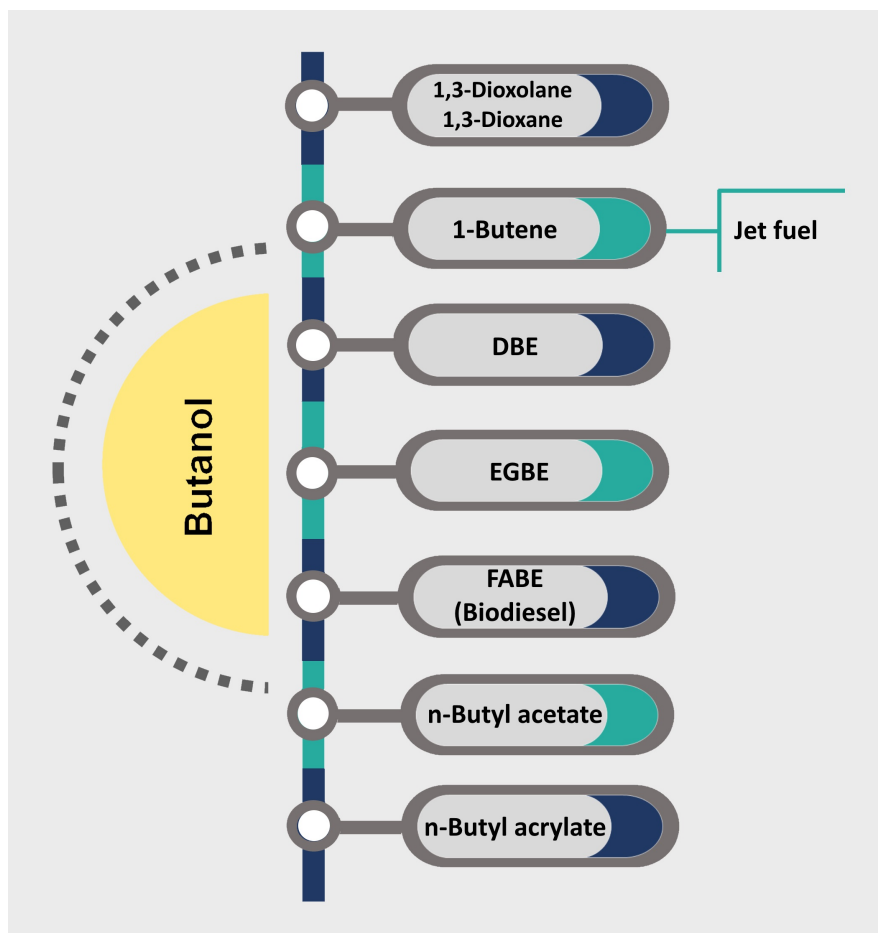

Fig. 5. Representative butanol-derivatives with fuel properties; DBE, dibutyl ether; EGBE, monoethylene glycol butyl ether; and FABE, fatty acid butyl esters.

applied as a diesel blend around $4 \mathrm{wt} . \%$. The butanol-derived fuel additives are shown in Figure 5.

\section{Ammonia \\ 5.1. Background and possibilities}

Although $\mathrm{NH}_{3}$ is gaseous at temperatures higher than $-33{ }^{\circ} \mathrm{C}$, it can easily be converted into a liquid state at a low pressure (about $0.1 \mathrm{MPa}$ ) without the use of special high-pressure tanks that are typically used for other gases such as $\mathrm{CO}_{2}$ and $\mathrm{H}_{2}$; thus justifying its consideration as a liquid fuel. Indeed, $\mathrm{NH}_{3}$ is a high-density non-petroleum environmentally compatible liquid fuel (Table 10) which releases energy rapidly upon combustion. While the fuel mileage with use of $\mathrm{NH}_{3}$ is half that of gasoline, it has no carbon emission when combusted. Interestingly, $\mathrm{NH}_{3}$ is a potent $\mathrm{H}_{2}$ storage carrier (17.6\%), which could solve different drawbacks of using $\mathrm{H}_{2}$ as fuel such as volatility and explosiveness. The idea of using $\mathrm{NH}_{3}$ as a biofuel was developed in the $1980 \mathrm{~s}$ (Strickland, 1981); however, investigations into using $\mathrm{NH}_{3}$ to power car engines dates back to 1905 when Fiat Company (Italy) obtained the first patent on $\mathrm{NH}_{3}$ fuel but subsequent vehicular applications by the Ammonia Cascale Company (Italy) were limited (Kroch, 1945; Stockes, 2007). In 1941 and 1942, $\mathrm{NH}_{3}$ was successfully used to operate a fleet of 100 buses in Belgium during a time of shortage of traditional fuels due to World War II (Kroch, 1945; Stockes, 2007). There are also records for existence of $\mathrm{NH}_{3}$ truck in 1933 (Holbroock, 2007), and more developed one that works on a mixture of $\mathrm{NH}_{3}$-gasoline with 4:1 ratio (Zamfirescu and Dincer, 2009). The availability of a distribution infrastructure, narrow range of flammability, rapid dissipation in air, and strong characteristic smell at even low concentrations for easy detection made $\mathrm{NH}_{3}$ a unique alternative to conventional fuels at the time (Christensen et al., 2006; Thomas and Parks, 2006).

Interestingly, since the $\mathrm{NH}_{3}$ molecule contains no $\mathrm{C}$, its complete combustion results in the formation of only nitrogen gas $\left(\mathrm{N}_{2}\right)$ and $\mathrm{H}_{2} \mathrm{O}$ vapor. Even though $\mathrm{NH}_{3}$ (Table 10) has high octane rating (i.e., 110-130), its flame speed is too slow to be directly used in ICE, thus necessitating engine modifications that feature compression ratios ranging from 40:1 to 100:1 (Van Blarigan, 2000; Feibelman and Stumpf, 2006), which are four times greater than that for regular ICEs. The presence of $\mathrm{H}_{2}$ in $\mathrm{NH}_{3}$ can boost the combustion process (Brandhorst et al., 2008). Moreover, $\mathrm{NH}_{3}$ can be thermally degraded into $\mathrm{N}_{2}$ and $\mathrm{H}_{2}$ by adsorption of approximately $12 \%$ of its higher heating value (HHV) (Jensen et al., 2007). The emission of $\mathrm{NO}_{\mathbf{x}}$ can be nullified when fuel-air ratio (excess air over five) is adjusted (Wend and Sternling, 1974). Another obstacle in application of $\mathrm{NH}_{3}$; i.e., toxicity has been previously addressed. For example, one method is passing $\mathrm{NH}_{3}$ over an anhydrous magnesium chloride powder at ambient temperature to adsorb porous metal ammine complexes from $\mathrm{NH}_{3}$ in the form of hexaamminemagnesium chloride $\left[\mathrm{Mg}\left(\mathrm{NH}_{3}\right)_{6} \mathrm{Cl}_{2}\right]$ (Zamfirescu and Dincer, 2009). A unique advantage of $\mathrm{NH}_{3}$ for on-board application is its cooling property that allows downsizing of engine cooling system and providing some air conditioning. This ability can efficiently compensate for any energy consumed for cooling purposes in regular engine machines working through burning fossil fuels (Zamfirescu and Dincer, 2009).

Table 10.

Fuel properties of ammonia.

\begin{tabular}{ll}
\hline Chemical formula & \\
Structure & 17.03 \\
Molar mass $(\mathrm{g} / \mathrm{mol})$ & -33.34 \\
Boiling point $\left({ }^{\circ} \mathrm{C}\right)$ & -77.73 \\
Melting point $\left({ }^{\circ} \mathrm{C}\right)$ & 0.73 \\
Density $\left(\mathrm{kg} / \mathrm{m}^{3}\right)$ & 651 \\
Ignition temperature $\left({ }^{\circ} \mathrm{C}\right)$ & 132 \\
Flash point $\left({ }^{\circ} \mathrm{C}\right)$ & $2.4 \times 10^{-3}$ \\
Thermal expansion coefficient $\left(\mathrm{K}^{-1}\right)$ & 22.5 \\
Calorific value $(\mathrm{MJ} / \mathrm{kg})$ & 6.06 \\
Air-fuel ratio $(\mathrm{kg} / \mathrm{kg})$ & $7500 \mathrm{mmHg}$ at $25^{\circ} \mathrm{C}$ \\
Vapor pressure & 1.37 at $25^{\circ} \mathrm{C}$ \\
Heat of vaporization $(\mathrm{MJ} / \mathrm{kg})$ & $15.5-27$ \\
Flammability limits $(\mathrm{Vol} \%$ in air $)$ & 0.6819 \\
Specific gravity at $20{ }^{\circ} \mathrm{C}$ and $1 \mathrm{~atm}$ & $110-130$ \\
Research octane $\mathrm{No}$. & \\
\hline
\end{tabular}

Overall, development of compatible technologies for production, distribution, and storage, may make global $\mathrm{NH}_{3}$-based vehicular applications attractive considering the zero carbon emission property upon combustion. Fuel properties of $\mathrm{NH}_{3}$ in comparison with other fuels currently used in the transportation industry are presented in Table 11.

\subsection{Chemical synthesis of ammonia}

$\mathrm{NH}_{3}$ is industrially produced using the Haber-Bosch process (costing $\sim 495 \mathrm{USD} / \mathrm{t} \mathrm{NH}_{3}$ ) in which $\mathrm{N}_{2}$ from air is reacted with $\mathrm{CH}_{4}$-derived $\mathrm{H}_{2}$ in the presence of a $\mathrm{Ru}$ or $\mathrm{Fe}$ catalyst to generate $\mathrm{NH}_{3}$ (Smil, 2001; Li et al., 2019). The process, however, is accomplished at high temperature and pressure; typically, at $475{ }^{\circ} \mathrm{C}$ and $20 \mathrm{MPa}$, respectively. Additionally, for every metric ton of $\mathrm{NH}_{3}$ produced, two metric tons of $\mathrm{CO}_{2}$ are generated, and the recovery efficiency of $\mathrm{NH}_{3}$ is about $38 \%$, both of which have adverse economic and environmental implications.

\subsection{Microbial production of ammonia}

The production of $\mathrm{NH}_{3}$ from non-fossil fuels can have an important effect on reduction of carbon and GHG footprints owing to the potential reduction in the amount of natural gas and other conventional fuels currently being used for its production. At least 24 bacterial genera, mostly isolated from the digestive tracts of ruminants and swine manure, have been used to produce different amounts of $\mathrm{NH}_{3}$. The hyper $\mathrm{NH}_{3}$-producing bacteria belong primarily to the genera Clostridium, Eubacterium, 
Table 11.

Properties of ammonia in comparison to gasoline and liquefied petroleum gas.*

\begin{tabular}{|c|c|c|c|c|c|c|c|c|}
\hline Fuel/Storage & $\begin{array}{c}\text { Pressure } \\
\text { (Mpa) }\end{array}$ & $\begin{array}{l}\text { Density } \\
\left(\mathrm{kg} / \mathrm{m}^{3}\right)\end{array}$ & $\begin{array}{c}\text { Calorific } \\
\text { value } \\
(\mathrm{MJ} / \mathrm{kg}) \\
\end{array}$ & $\begin{array}{c}\text { Peak flame } \\
\text { temperature } \\
\left({ }^{\circ} \mathrm{C}\right)\end{array}$ & $\begin{array}{l}\text { Price in } 2019 \\
\text { (US\$/L) }\end{array}$ & $\begin{array}{c}\text { Energy/Exergy density } \\
\left(\mathbf{G J} / \mathbf{m}^{3}\right)\end{array}$ & $\begin{array}{l}\text { Energetic cost }{ }^{\text {a }} \\
\text { (US\$/GJ) }\end{array}$ & $\begin{array}{c}\mathrm{CO}_{2} \text { emission } \\
\text { through } \\
\text { combustion }\end{array}$ \\
\hline Gasoline/liquid tank & 0.1 & 71.9-76 & 46.7 & 1977 & 1.10 & $34.4 / 34.3$ & 27.7 & Yes \\
\hline $\mathrm{NH}_{3} /$ pressurized tank & 1 & 73 & 22.5 & 1850 & 0.44 & $13.6 / 11.9$ & 12.6 & No \\
\hline LPG/pressurized tank & 1.4 & $52.5-58$ & 48.9 & 1884 & 0.60 & $19.0 / 11.6$ & 27.1 & Yes \\
\hline
\end{tabular}

${ }^{a}$ Fuel cost per unit of tank volume

LPG: liquefied petroleum gas; and $\mathrm{NH}_{3}$ : Ammonia

* Source: Zamfirescu and Dincer (2009), Widmar (2019), and https://www.globalpetrolprices.com

Fusobacterium, Peptostreptococcus, and Pseudomonas, which when used have productivities as great as $681 \mathrm{mg} / \mathrm{L} / \mathrm{d}$ (Whitehead and Cotta, 2004; Latvala et al., 2014).

The treatment of biological wastes such as agricultural residues, animal manures, animal blood from slaughterhouses, etc. utilizing anaerobic digestion processes is becoming attractive considering the human population growth and associated increased waste generation (Shirzad et al., 2019). For example, approximately 700 million tons/yr of animal manure are produced in the USA, with potential effects on air and water quality as well as ecological consequences such as eutrophication. Notably, $\mathrm{NH}_{3}$ is one of the gases produced during anaerobic digestion. Approximately 1,700 (large scale), 17,400 (out of which 300 are large scale), 102,700, and 2,000,000 anaerobic digestion facilities are currently operational in USA, Europe, China, and India, respectively (Ho, 2005; Baere and Mattheeuws, 2010; USEPA, 2012; Scarlat et al., 2018; Shirzad et al., 2019). The $\mathrm{NH}_{3}$ and ammonium ion $\left(\mathrm{NH}_{4}{ }^{+}\right)$, referred to as total ammonia nitrogen (TAN) which are interconvertible depending on pH and temperatures (Eqs. 2 and 3) (Rittmann and McCarty, 2012), are produced as a result of operation of these digesters. More specifically, the higher $\mathrm{pH}$ and temperature leads to the lesser proportion of $\mathrm{N}$ flux that is in form of $\mathrm{NH}_{4}^{+}$. Thus, $\mathrm{pH}$ and temperature conditions in the digester can be manipulated and exploited to produce and recover $\mathrm{NH}_{3}$ from anaerobic digesters.

$\mathrm{NH}_{4}^{+} \leftrightarrow \mathrm{NH}_{3}+\mathrm{H}^{+}$

$\left[\mathrm{NH}_{3}-\mathrm{N}\right]=([\mathrm{TAN}]) /((1+([\mathrm{H}+]) / \mathrm{Ka})$

where, $\left[\mathrm{NH}_{3}-\mathrm{N}\right]$ is the concentration of $\mathrm{N}$ in $\mathrm{NH}_{3}$ and $K_{a}$ is the temperature dependent dissociation coefficient.

To improve $\mathrm{NH}_{3}$ production during anaerobic digestion, Babson et al. (2013) developed an approach in the process that shifts the production of $\mathrm{CH}_{4}$ towards $\mathrm{NH}_{3}$ synthesis. By adjusting the $\mathrm{C}: \mathrm{N}$ ratio in the digestion feedstock, approximately $61 \%$ of total $\mathrm{N}$ flux was converted to $\mathrm{NH}_{3}$ (Babson et al., 2013). Integration of a separate hydrolysis fermenter upstream of the anaerobic digester has been reported to prevent $\mathrm{NH}_{3}$ toxicity to fermenting microorganisms and enhance digester stability (Babson et al., 2013). A novel process was patented in 2014 involving enzymatic hydrolysis of food industry wastes followed by microbial submerged fermentation (preferably Clostridium spp. deposited as VTT E- 123272 and VTT E- 123273) at optimized conditions (Latvala et al., 2014). At the end of fermentation process, TAN is recovered by using $\mathrm{NH}_{3}$ gas capturing technologies while stripping is used to convert the ionic form $\left(\mathrm{NH}_{4}^{+}\right)$to $\mathrm{NH}_{3}$ or alternatively, precipitation or mechanical methods may be used to recover $\mathrm{NH}_{4}^{+}$(Latvala et al., 2014).

\subsection{Ammonia recovery}

Air or stream stripping is typically used for the recovery of $\mathrm{NH}_{3}$ from $\mathrm{NH}_{3-}$ laden effluents from landfill leachate, municipal waste water treatment facilities, slaughterhouse waste digesters, dairy anaerobic digestion, and biogas plants (Jiang et al., 2010; Errico et al., 2018; Mavinic et al., 2019). Because $\mathrm{NH}_{3}$ is easily dissociable in caustic solution, the stripping technique often involves a pretreatment step in which the $\mathrm{pH}$ of the effluent is increased using sodium hydroxide $(\mathrm{NaOH})$ or limestone through multiple mixing operations in a stirred tank reactor. The resulting flocculated inorganic compounds such as carbonates, phosphates, and sulfates are either separated after conducting the alkalization process in the sedimentation basins or retained throughout the entire process. The treated effluent stream is introduced at the top of the packed bed column from where it flows down to meet a counter-current air (lower operating costs) or steam (higher efficiency) flow that strips the $\mathrm{NH}_{3}$ from the liquid phase. The $\mathrm{NH}_{3}$ gas and treated $\mathrm{H}_{2} \mathrm{O}$ are collected at the top and sump of the column, respectively. Further purification and treatment may include $\mathrm{NH}_{3}$ distillation $\left(\mathrm{NH}_{3}-\mathrm{H}_{2} \mathrm{O}\right.$ or anhydrous $\left.\mathrm{NH}_{3}\right)$, absorption with an acid (salt solution) in a scrubber, and subsequent incineration. In the distillation step, $\mathrm{NH}_{3}$ and $\mathrm{H}_{2} \mathrm{O}$ vapors are passed through a condenser (low temperature) or a high-pressure column to form anhydrous $\mathrm{NH}_{3}$. The cost of refrigeration makes the use of a condenser for the fractionation of $\mathrm{NH}_{3}-\mathrm{H}_{2} \mathrm{O}$ to pure $\mathrm{NH}_{3}$ economically unattractive when compared to the pressurized column operating at about $1.4 \mathrm{MPa}$ and temperature of $38^{\circ} \mathrm{C}$, which is amenable to use of cooling water for the fractionation of $\mathrm{NH}_{3}-\mathrm{H}_{2} \mathrm{O}$ vapors. From the biofuel industry perspective, stripping of $\mathrm{NH}_{3}$ with steam is preferable as it allows the production of $\mathrm{NH}_{3}$ with fewer contaminants. The ion exchange method of $\mathrm{NH}_{3}$ recovery has not gained much attention due to the lack of capacity for utilization of large amounts of solids $(<1 \%)$ with the use of this technology (Jiang et al., 2010).

5.5. Ammonia derivatives as fuel components: production, applications, and performance

In addition to being a potential transportation fuel, $\mathrm{NH}_{3}$ can be used for production of fuel additives and feedstock chemicals that may be used in the production of fuels (Fig. 6). Oil soluble polyamines have been applied as dispersant additive to improve fuel detergency, which enhances the removal or prevention of deposits in the combustion chamber (Koehler and Claffey, 1999). Reaction of $\mathrm{NH}_{3}$ with methanol in the presence of an $\mathrm{Al}_{2} \mathrm{O}_{5} \mathrm{Si}$ catalyst leads to formation of three products, which includes monomethylamine (MMA), dimethylamine (DMA), and trimethylamine. These methylamines can be used as rocket fuels and fuel additives. Furthermore, a reaction between MMA and chlorobenzene $\left(\mathrm{C}_{6} \mathrm{H}_{5} \mathrm{Cl}\right)$ in the presence of $\mathrm{Cu}$ as a catalyst results in generation of $n$-methylaniline. Both $n$-methylaniline and dimethylamine hydrochloride (DMA-HCl) are important chemicals used in the production of "antiknock" aviation fuel additive. There have been suggestions that DMA could be a potential gasoline additive with a $10 \%(\mathrm{v} / \mathrm{v})$ DMA incorporation to gasoline to increase the octane number of gasoline by five (Ezeldin et al., 2015). With the reaction between DMA salt and sodium nitrate $\left(\mathrm{NaNO}_{3}\right)$, there is generation of dimethylnitrosamine (DMNA) which can be oxidized with chloramine $\left(\mathrm{NH}_{2} \mathrm{Cl}\right)$ to produce 1,1-dimethylhydrazine (UDMH), a propellant for rockets. Dimethylaminopropylamine (DMAPA) is produced by reacting DMA with acrylonitrile $\left(\mathrm{C}_{3} \mathrm{H}_{3} \mathrm{~N}\right)$ in a process referred to as Michael reaction followed by a hydrogenation step. The generated compound which contains one primary and a tertiary amine group serves as an intermediate feedstock for the production of various fuel additives (Huntsman, 2017). For example, when DMAPA is reacted with polyisobutenyl chloride, a fuel additive is produced which is capable of preventing engine fouling and reducing $\mathrm{HC}$ exhaust gas emissions. A reaction between $\alpha, \beta$-dibromopropionitrile and DMAPA can be utilized for generation of an effective carburetor cleaner. Other carburetor detergents have also been produced by reacting DMAPA with alkylphenols and aldehydes or with thioglycolic acid and chlorinated polyisobutene (Huntsman, 2017). Furthermore, ash-free lubricant additives have been 
produced by using a reaction between DMAPA and $\mathrm{C}_{2} \mathrm{H}_{4}, \mathrm{C}_{3} \mathrm{H}_{6}$, or 1,4 hexadiene copolymer. Indeed, Huntsman (2017) formulated a lubricating oil additive with improved anti-corrosion, dispersancy, and anti-wear properties by reacting DMAPA with alkyl phenol, formaldehyde, and sulfur.

In addition to methanol, $\mathrm{NH}_{3}$ can be reacted with ethanol to produce fuel additives. For example, the reaction of $\mathrm{NH}_{3}$ and ethanol results in generation of diethanolamine (DEA), an industrial amine that confers lubricity and anti-wear properties to fuels. While some of these reactions do not generally result in production yields that justify commercialization, there can be platforms developed utilizing this knowledge for further research to bring to fruition the development of $\mathrm{NH}_{3}$ as a non-carbon fuel.

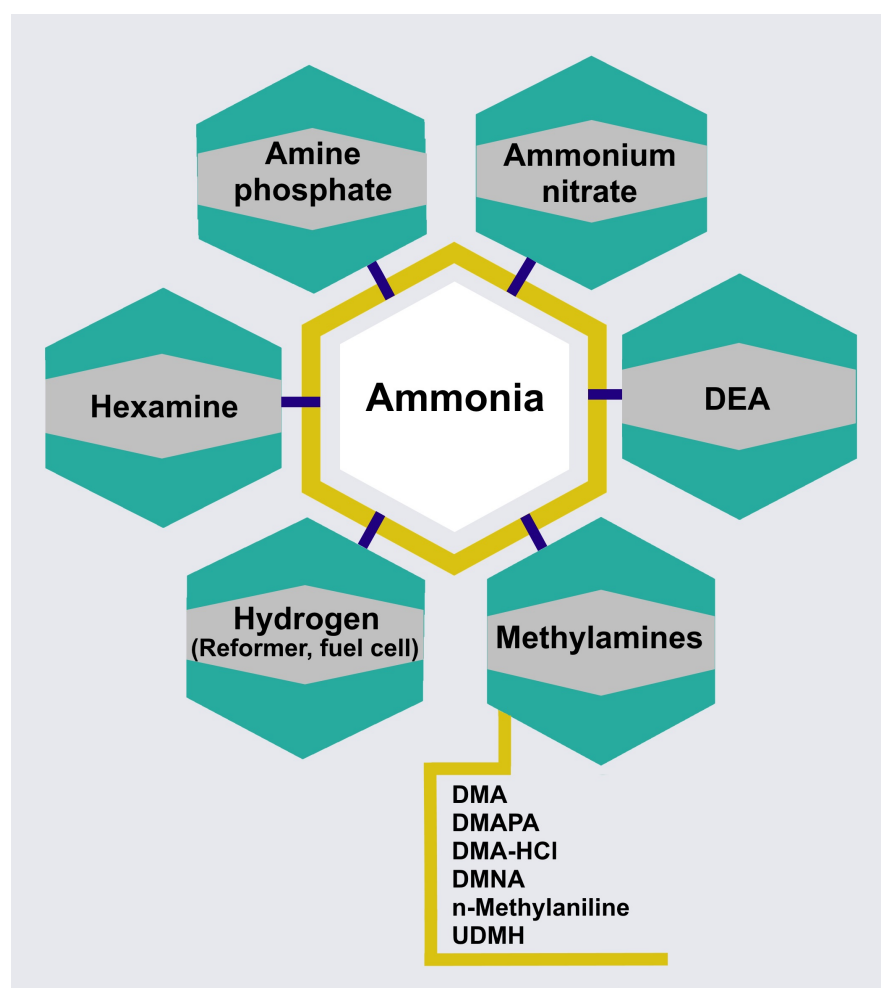

Fig. 6. Fuels and fuel additives from ammonia; DEA, diethanolamine; DMA, dimethylamine; DMA-HCl, dimethylamine hydrochloride; DMAPA, dimethylaminopropylamine; DMNA, dimethylnitrosamine; and UDMH, 1,1-dimethylhydrazine.

\section{Bio-jet fuels (biokerosene)}

\subsection{Background and possibilities}

The aviation industry is an essential part of modern mobility of people, goods, and services. Aviation transportation is responsible for the release of $2.4 \%$ of the $13.5 \%$ global $\mathrm{CO}_{2}$ released by the transport sector. In 2018 , up to 346 million $\mathrm{m}^{3}$ ( 2.72 billion barrels) of jet-fuel was consumed which is expected to reach 441 million $\mathrm{m}^{3}$ ( $\sim 3.47$ billion barrel) in 2040 . The rapid growth in jet-fuel consumption in 2018 conveniently exceeded by $4 \%$ (typical expectations of $1-3 \%$ ) compared with value recorded in the preceding years (Babau et al., 2013; Holbrook, 2018). Commercial airplanes are generally operated with jet kerosene, a relatively safe energy dense fuel with desirable combustion quality. A summary of the fuel properties of kerosene are included in Table 12. Kerosene is an oil distillate, which can also be extracted from oil shale, coal, and wood. The methods of kerosene production from petroleum will not be included in this review. There, however, will be inclusion of information about biosynthesis processes involving microbial conversion of organic matter into kerosene or its intermediate compounds.
Table 12.

Fuel properties of kerosene.

\begin{tabular}{ll}
\hline Chemical formula & Mixture of hydrocarbons $(\mathrm{C} 9$ to $\mathrm{C} 16)$ \\
Molar mass $(\mathrm{g} / \mathrm{mol})$ & 170.34 \\
Boiling Point $\left({ }^{\circ} \mathrm{C}\right)$ & $15-300$ \\
Melting point $\left({ }^{\circ} \mathrm{C}\right)$ & -20 \\
Density $\left(\mathrm{kg} / \mathrm{m}^{3}\right)$ & 800 \\
Ignition temperature $\left({ }^{\circ} \mathrm{C}\right)$ & 220 \\
Flash point $\left({ }^{\circ} \mathrm{C}\right)$ & $37-65$ \\
Thermal expansion coefficient $\left(\mathrm{K}^{-1}\right)$ & $9.6 \times 10^{-4}$ \\
Viscosity $\left(\mathrm{m}^{2} / \mathrm{s}\right)$ & $2.39 \times 10^{-4}$ \\
Calorific value $(\mathrm{MJ} / \mathrm{kg})$ & 35 \\
Air-fuel ratio $(\mathrm{kg} / \mathrm{kg})$ & 15.6 \\
Vapor pressure & $0.7 \mathrm{kPa}$ \\
Heat of vaporization $(\mathrm{MJ} / \mathrm{kg})$ & 43.1 \\
Octane No. & $15-20$ \\
\hline
\end{tabular}

\subsection{Microbial production of bio-jet fuel}

The Amyris direct sugar to hydrocarbon (DSHC) process is probably the most desirable method for the production of bio-jet fuel as the process can be utilized for generation of aviation kerosene that meets the American Society for Testing and Materials (ASTM) D7566 specifications (Neuling and Kaltschmitt, 2015). The use of the process results in conversion of sugars from corn, sugarcane, and lignocellulosic biomass to $\mathrm{C}_{15}$ alkenes that are termed Farnesenes $\left(\mathrm{C}_{15} \mathrm{H}_{24}\right)$, and other by-products through utilization of the mevalonate pathway with genetically engineered yeast and enzymes as biocatalysts in an advanced aerobic fermenter. The production of the enzymes and the cultivation of the yeast are performed in separate vessels (Saha et al., 2005). The generated $\mathrm{C}_{15} \mathrm{H}_{24}$ is extracted and saturated to form Farnesane $\left(\mathrm{C}_{15} \mathrm{H}_{32}\right)$ by using hydrotreating processes. This process can be used to generate valuable compounds for the chemical and pharmaceutical industries (Saha et al., 2005). In 2015 the Amyris DSHC process is operated on a small-scale, generating approximately 24,000 tons $\mathrm{C}_{15} \mathrm{H}_{32}$ per annum in Brotas, Brazil (Neuling and Kaltschmitt, 2015).

Alcohol-to-jet fuel (AtJ) is another method through which organic materials can be converted into jet fuel using fermenting microorganisms and enzymes as biocatalysts. In this process, alcoholic feedstocks such as ethanol and butanol which have been previously produced through microbial fermentation of sugar, starch, or lignocellulose-containing raw materials, are dehydrated using acid $\left(\mathrm{H}_{3} \mathrm{PO}_{4}\right.$ or $\left.\mathrm{H}_{2} \mathrm{SO}_{4}\right)$ catalytic reactions at 170 to $200{ }^{\circ} \mathrm{C}$ in the presence of metal oxide catalysts to form alkenes (Breitmaier and Jung, 2005; Wollrab, 2009; Pechstein et al., 2018). Catalytically controlled oligomerization of generated short-chain alkenes $\left(\mathrm{C}_{4} \mathrm{H}_{10}\right.$ or $\left.\mathrm{C}_{2} \mathrm{H}_{6}\right)$ to longer molecules is subsequently performed (Neuling and Kaltschmitt, 2015). The generated product is separated and treated with $\mathrm{H}_{2}$ to saturate alkenes to alkanes in the presence of a catalyst such as $\mathrm{Ni}$, palladium (Pd), or Pt. A fuel cocktail comprising 48\% kerosene, 35\% gasoline, and $17 \%$ diesel is obtained (Hull, 2012). Although the reaction can be performed at ambient pressure and temperature, the performance can be improved at greater pressures and/or temperatures (Breitmaier and Jung, 2005). Byogy Renewables Inc. is the leading company that has adapted the AtJ process for the production of kerosene using ethanol and $\mathrm{H}_{2}$ as feedstocks (Weiss, 2013). Similarly, LanzaTech/Swedish Biofuels produce ethanol from gasified biomass or industrial waste gases utilizing synthesis gas fermentation processes followed by the use of AtJ method for conversion of ethanol and $\mathrm{C}_{4} \mathrm{H}_{8}$ to kerosene (Holmgren, 2013). Gevo uses the AtJ process to produce synthetic paraffinic kerosene from isobutanol derived from fermentation of hydrolyzed lignocellulosic biomass (Johnston, 2013). For examples, Gevo operates a small demonstration plant with a total production capacity of about 290 tons/yr in Silsbee, Texas, and Swedish Biofuels operates a working pilot plant producing 10 metric tons/yr bio-jet fuel in Stockholm, Sweden (Hull, 2012; Johnston, 2013). 
Table 13.

Comparison of various microbial techniques for bio-kerosene production with commercial HEFA processing. Source: Neuling and Kaltschmitt (2015).

\begin{tabular}{|c|c|c|c|c|c|c|c|c|}
\hline Process & Feedstock & Additive & $\begin{array}{c}\text { Process } \\
\text { complexity }^{\text {a }}\end{array}$ & $\begin{array}{l}\text { Kerosene } \\
\text { efficiency }\end{array}$ & $\begin{array}{c}\text { Overall } \\
\text { efficiency }\end{array}$ & $\begin{array}{l}\text { Production } \\
\operatorname{cost}^{b}\end{array}$ & Market maturity & $\begin{array}{c}\text { Developmental } \\
\text { potential }\end{array}$ \\
\hline HEFA & $\begin{array}{l}\text { All types of oils } \\
\text { and fats }\end{array}$ & $\begin{array}{l}\text { Large amount of } \mathrm{H}_{2} ; \mathrm{NiMo} / \mathrm{Al}_{2} \mathrm{O}_{3} \text {, } \\
\text { zeolites (ZSM) or Pt metal } \\
\text { catalysts }\end{array}$ & - & $<50 \%$ & $<60 \%$ & - & $\begin{array}{l}\text { Commercially } \\
\text { operated }\end{array}$ & Low \\
\hline Amyris DSHC & Biomass ${ }^{\mathbf{b}}$ & Low amount of $\mathrm{H}_{2}$ & Higher & About $97 \%$ & $<97 \%$ & Higher & Demo-plant & High \\
\hline AtJ & Biomass & $\begin{array}{l}\text { Low amount of } \mathrm{H}_{2} ; \mathrm{Ni}, \mathrm{Pt}, \mathrm{Pd} \\
\text { catalysts }\end{array}$ & Similar & $48 \%$ & NA & Higher & $\mathrm{R} \& \mathrm{D}$ process & High \\
\hline Bio-GtL & $\begin{array}{l}\text { Biomass except } \\
\text { lignin }\end{array}$ & $\begin{array}{l}\text { Large amount of } \mathrm{H}_{2}, \mathrm{O}_{2} \text {, and } \\
\text { solvents for } \mathrm{CO}_{2} \text { separation; } \\
\text { Co or Ru catalysts }\end{array}$ & Similar & $50-60 \%$ & NA & $\begin{array}{l}\text { Similar/ } \\
\text { Higher }\end{array}$ & $\mathrm{R} \& \mathrm{D}$ process & Medium \\
\hline
\end{tabular}

HEFA, hydroprocessed esters and fatty acids; NA, not applicable; DSHC, direct sugar to hydrocarbon; AtJ, alcohol-to-jet; R\&D, research and development; GtL, gas-to-liquid

${ }^{\text {a }}$ Compared to HEFA

${ }^{\mathbf{b}}$ Starch, sugar and lignocellulosic biomass

Intriguingly, Gevo's AtJ was utilized as a $20 \%$ blend in a test commercial flight by Alaska Airlines and the fuel met the international ASTM standards (Alaska Airlines, 2016; Gevo Inc, 2016).

Gas-to-liquid (GtL) processes as a potential cost effective microbial process for the production of kerosene has also been investigated. With this method, $\mathrm{CH}_{4}$ derived from anaerobic digestion of various organic wastes (such as corn silage, grass silage, and sugar beets) can be transformed into bio-kerosene via syngas to gasoline plus (STG+) process with a thermochemical single-loop or FT process (LaMonica, 2012; Shirzad et al., 2019; Tabatabaei et al., 2019b). GtL process for kerosene production is attractive because the anaerobic digestion technology for the production of the chief feedstock $\left(\mathrm{CH}_{4}\right)$ is mature and economically viable (if all benefits of anaerobic digestion process are considered) (Neuling and Kaltschmitt, 2015; Shirzad et al., 2019). The process is initiated with the breakdown of $\mathrm{CH}_{4}$ to $\mathrm{CO}$ and $\mathrm{H}_{2}$ using steam $\mathrm{CH}_{4}$ reforming, POX, or autothermal reforming (ATR), which results in the generation of a $\mathrm{H}_{2}$ : $\mathrm{CO}$ mixture (i.e., syngas) (De Klerk, 2012). In the STG+ process, the syngas is transferred sequentially through two reactors with compatible catalysts to generate methanol, which is dehydrated to form DME (see Section 2.4). In the third reactor, the DME is catalytically transformed into HCs including kerosene, aromatics, naphthenes, and trace amounts of olefins. The fourth and last reactor is where transalkylation and hydrogenation steps occur resulting in the reduction of durene and trimethybenzene contents of the $\mathrm{HCs}$ to improve the octane rating and desirable viscometric properties of the generated fuel. Following separation of gas and liquid products, residual gases are recycled to the feed stream of the first reactor whereas the liquid fuel that is composed of kerosene, aromatics and naphthenes is transferred to a storage tank http://www.primusge.com/press-room/white-papers/.

In the FT process, the $\mathrm{H}_{2}: \mathrm{CO}$ ratio is adjusted using the $\mathrm{H}_{2} \mathrm{O}$-gas shift process while the excess $\mathrm{CO}_{2}$ is removed either with compatible solvents or dissolved in aqueous solutions of alkanolamines. The syngas is then converted into long-chain $\mathrm{HCs}$ in a reaction that uses $\mathrm{Co}, \mathrm{Fe}$, or Ru catalyst. Table 13 presents comparison between processes used for the production of bio-kerosene with the commercial hydro-processed esters and fatty acids (HEFA) process (Neuling and Kaltschmitt, 2015). The HEFA process involves hydrogenation of triglycerides followed by isomerization to branched alkanes to meet the ASTM D7566 specifications, and separation using distillation procedures. These reaction processes are conducted at an elevated pressure (10 MPa) and a high temperature $\left(400{ }^{\circ} \mathrm{C}\right)$. Notably, the use of the HEFA process allows for algal and microbial triglycerides to be used as feedstocks for kerosene production (Robota et al., 2013; Yeh et al., 2013), an important development decreasing the reliance on food-grade vegetable oils such as palm, rape, peanut and soybean oils as feedstock.

\section{Glycerol}

\subsection{Background and possibilities}

Glycero can be produced naturally by some microorganisms, e.g., $S$. cerevisiae or by chemical synthesis in the petrochemical and soap industries. Glycerol is also a major co-product of the biodiesel industry, where animal fats and vegetable oils (both containing long chain fatty acids) are converted into biodiesel by reaction of these feedstocks with short-chain alcohols such as ethanol or methanol (Tabatabaei et al., 2019a). The reaction process, termed the transesterification reaction, can be accelerated by addition of heat and catalysts such as $\mathrm{KOH}$, sodium methoxide $\left(\mathrm{CH}_{3} \mathrm{ONa}\right)$, and $\mathrm{NaOH}$. The transesterification of triglycerides results in the formation of mono-alkyl ester (biodiesel) and approximately $10 \%$ to $15 \%$ crude glycerol (co-product) (Quispe et al., 2013; Tabatabaei et al., 2019a).

Microbial production of glycerol for use as a biofuel is not technically and economically feasible (Wang et al., 2001; Quispe et al., 2013). More specifically, when glycerol is combusted, there cannot be maintained a stable flame in a conventional combustion system due to its low calorific value and/or presence of $\mathrm{H}_{2} \mathrm{O}$ in the mixture. Glycerol is viscous at ambient temperatures, thus, rendering atomization with conventional atomizers problematic (Tabatabaei et al., 2019a). Crude glycerol, especially as a coproduct of the biodiesel industry, contains salts, which are corrosive in combustion injectors and in post combustion systems. Alternatively, glycerol can be combusted in specially-designed boilers for the generation of heat and electricity (Quispe et al., 2013). The production of combustible pellets by mixing waste glycerin with waste biomass for substitution of coa for energy generation is another option (Brady et al., 2008). Some properties of glycerol are described in Table 14. The application of glycerin as a fuel additive has been studied by Mota et al. (2010). When there was blending of solketal (glycerin reacted with ketal) with gasoline in amounts as much as $5 \%(\mathrm{v} / \mathrm{v})$, the octane number of the gasoline-glycerol blend was increased by 2.5 points, and there was decreased gum formation Additionally, the potential blending of gasoline with derivatives of glycerol such as propanediol and propanol as oxygenates has been suggested (Fernando et al., 2007). These derivatives and other valuable products such as citric acid, dihydroxyacetone, ethanol, LA, pigments, polyhydroxyalcanoate, propionic acid (PA), and SA can be synthesized through utilization of a compatible microorganism.

\subsection{Microbial production of glycerol}

Glycerol production using chemical synthetic procedures is no longer an attractive process mainly due to impractical economic cost of the major precursor for this process, i.e., $\mathrm{C}_{3} \mathrm{H}_{6}$, on one hand and the improvements made in microbial fermentation and glycerol recovery techniques on the other hand (Hester, 2000). The technology shift for glycerol production has also occurred because of the marked replacement of conventional animalfat-based-soap with detergents. Currently, glycerol is still applied as humectant in some types of soap or other cosmetic products available in the market. The fermentation process can occur with use of various microorganisms such as bacteria (B. subtilis, Bacillus welchii and 
Table 14.

Fuel properties of glycerol.

\begin{tabular}{ll}
\hline Chemical formula & \\
Structure & 290 \\
Molar mass $(\mathrm{g} / \mathrm{mol})$ & 17.8 \\
Boiling Point $\left({ }^{\circ} \mathrm{C}\right)$ & 1126 \\
Melting point $\left({ }^{\circ} \mathrm{C}\right)$ & 393 \\
Density $\left(\mathrm{kg} / \mathrm{m}^{3}\right)$ & 176 \\
Ignition temperature $\left({ }^{\circ} \mathrm{C}\right)$ & 160 \\
Flash point $\left({ }^{\circ} \mathrm{C}\right)$ & 19 \\
Heat of vaporization $(\mathrm{cal} / \mathrm{g})$ & $5 \times 10^{-4}$ \\
Calorific value $(\mathrm{MJ} / \mathrm{kg})$ & $0.003 \mathrm{mmHg}$ at $50^{\circ} \mathrm{C}$ \\
Thermal expansion coefficient $\left(\mathrm{K}^{-1}\right)$ & 0.95 \\
Vapor pressure &
\end{tabular}

Lactobacillus lycopersici), yeasts (Candida boidinii, Candida magnolia $\mathrm{I}_{\mathrm{z}} \mathrm{B}_{\mathrm{a}}$, Candida glycerinogenes, Pichia farinose, S. cerevisiae, Saccharomyces ellipsoideus, and $Z$. rouxii), molds, and algae. While glycerol production using bacteria has been unattractive due to the slow fermentation rate and low yields of product (Wang et al., 2001), glycerol production with yeast, S. cerevisiae, has been relatively attractive and successful with the process currently being utilized commercially. Glycerol metabolism in $S$. cerevisiae occurs in the cytosol, and involves the glycolytic intermediate dihydroxyacetone phosphate (DHAP) through the catalytic activity of glycerol-3-phosphate dehydrogenase and glycerol-3-phosphatase (Wang et al., 2001). In anaerobic fermentation process using this yeast to produce glycerol, ethanol production should be retarded by trapping acetaldehyde in a complex through the addition of bisulfite ions (the steering agent). Under this condition, electron transfer from the cytosolic NADH to acetaldehyde cannot occur and instead, the accumulated $\mathrm{NADH}$ is oxidized through the reduction of DHAP to glycerol-3-phosphate. Alternatively, the fermentation can also be conducted as normal alcoholic fermentation at neutral or alkaline $\mathrm{pH}(7 \leq)$. In this process, NADH molecules are generated as the result of acetaldehyde oxidation to AA. When there is no $\mathrm{O}_{2}$ available, the re-oxidation of this NADH molecule takes place through DHAP reduction to glycerol-3-phosphate which is further converted into glycerol. Sparging of the bioreactor with $\mathrm{CO}_{2}$ or strict application of aeration control has been found to increase the efficiency of glycerol production to as great as $40 \%$ (Wang et al., 2001).

The relatively low glycerol titer in fermentation broth and its high cost of recovery are the main challenges for commercial bio-glycerol producers (Wang et al., 2001). These limitations can be mitigated by the development of osmotolerant yeasts without loss in glycerol producing capacity. Use of these yeast strains can result in fermentation of as much as $45 \%$ (w/w) of the total sugar with an improved glycerol production in an aerobic fermentation process with no requirement for steering or osmotic solutes. This process is simpler with reduced contamination risk when compared to conventional methods where bisulfites or alkali techniques are used for glycerol production. Commercial production of glycerol has been reported in a 50,000-L airlift fermenter with an average yield of 51 wt.\% using genetically-modified $C$. glycerinogenes (Zhuge et al., 2001).

Additionally, glycerol is produced as a co-product during ethanolic fermentation. The most feasible approach for the recovery of glycerol (about $90 \%$ ) from fermentation broth is by the use of a patented technique known as carrier-distillation in which cell debris and dissolved solids are initially removed by filtration followed by the addition of inorganic inert materials to the filtrate and distillation at 160 to $180{ }^{\circ} \mathrm{C}$ (Zhuge and Liu, 1990). This technique can be coupled to an ion-exchange chromatography for the production of medical grade glycerol. Other methods including a vacuum distillation technique have also been tested. While use of the ion exclusion method in conjunction with ion exchange has been reported to result in production of glycerol of high purity, the extensive pretreatment of the fermentation broth prior to glycerol recovery makes the process cost prohibitive (Zhuge et al., 2001).

In a cost-benefit analysis performed in the year 2000, the cost of microbial glycerol production was estimated to be between US\$400/t and US\$ 530/t, vs. its price of US\$ 1100/t to US\$ $1250 / \mathrm{t}$ in the same year indicating its profitability (Hester, 2000). However, this scenario drastically changed through the increasing establishment of the biodiesel industry resulting in surplus availability of as glycerol (the main co-product of the transesterification reaction) and consequent fall of glycerol market price.

\subsection{Glycerol derivatives as fuel additives: production, applications, and performance}

Conversion of glycerol to value-added products such as fuel additives (Fig. 7) has received remarkable attention in the past decade due to the surplus of glycerol that resulted from the increased production of biodiesel worldwide (Rahimzadeh et al., 2018; Tabatabaei et al., 2019a).

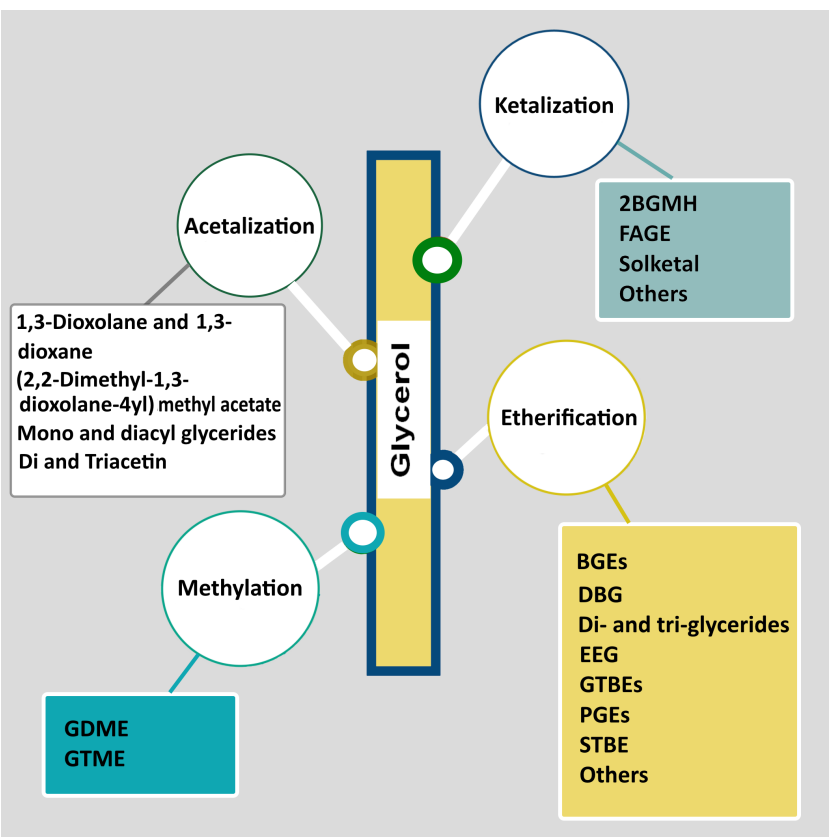

Fig. 7. Reported glycerol derivatives with fuel enhancing properties; 2BGMH, 2-butanoneglycerol and methyl hexonoate; BGE, butyl glycerol ethers; DBG, di-butoxy glycerol; EEG, ethyl ether of glycerol; FAGE, fatty acid formal glycerol ester; GDME, glycerol dimethoxy ether; GTBE, glycerol tert-butyl ethers; GTME, glycerol trimethoxy ether; PGE, propy glycerol ethers; and STBE, solketal tert-butyl ether.

The addition of ketal derivatives of glycerol into biodiesel improves cold flow properties and maintains iodine and viscosity values of the fuel blend. However, the free hydroxyl group of glycerol must be esterified prior to its addition into biodiesel to meet the EN14214 specifications with respect to the FAME content and oxidation stability (De Torres et al., 2012). Glycero ketal esters, a transesterified product of 2-butanone-glycerol and methyl hexonoate (2BGMH), has been proposed for use as a promising diesel fuel additive for the reduction of smoke emission in diesel engines (Oprescu et al., 2014; Tabatabaei et al., 2019a). Fatty acid formal glycerol ester (FAGE), produced from glycerol and used cooking oil or waste animal fats subjected to a transketalization-transesterification combined process, has been reported to improve the lubricity of the diesel fuel (Lapuerta et al. 2015). Glycerol can also be bio-converted to FAGE using an engineered $E$ coli strain YL15 with highly acceptable production efficiencies $(813 \mathrm{mg} / \mathrm{L})$ 
(Yang et al., 2013). The combustion of diesel containing 20\% FAGE, however, resulted in increased $\mathrm{NO}_{\mathrm{x}}, \mathrm{CO}$, and $\mathrm{PM}$ emissions at cold engine temperatures due to the high viscosity and poor volatility. The inclusion of solketal resulted in a reduction in gum formation and improvement in fuel octane point-number by 2.5. Shirani et al. (2014) produced solketal in a continuous reactor by ketalization of glycerol with use of subcritical acetone and Purolite ${ }^{\circledR}$ PD206 as a catalyst at $20^{\circ} \mathrm{C}$ and a pressure of $12 \mathrm{MPa}$ with a $95 \%$ product yield. Solketal can be converted into a novel biodiesel oxygenate additive such as solketal tertbutyl ether (STBE) using either batch or continuous flow processing (Vicente et al., 2010; Monbaliu et al., 2011; Tabatabaei et al., 2019a). While there has been some progress, the batch etherification of solketal with $\mathrm{C}_{4} \mathrm{H}_{8}$ remains to be a challenging approach due to the significant safety measures needed during industrial scale production as well as reagent immiscibility in the early reaction stage.

Furthermore, Spooner-Wyman et al. (2003) evaluated the production of dibutoxy glycerol (DBG) by etherification with isobutylene for use as a diesel fuel blend. The results of the study indicate that DBG is a promising diesel fuel additive with the capacity to reduce PM emissions during diesel combustion. Similarly, Noureddini et al. (1998) was able to induce catalytic etherification of glycerol with isobutylene at $80^{\circ} \mathrm{C}$ for 1 to $2 \mathrm{~h}$ and the corresponding glycerol ethers formed were compatible for use with diesel and biodiesel fuels. There was a reduction in the cloud point and viscosity of biodiesel by $5{ }^{\circ} \mathrm{C}$ and $8 \%$, respectively, when the glycerol ethers were blended at $20 \%$ in diesel and biodiesel fuels (Noureddini et al., 1998). Alternatively, Saengarun et al. (2017) reported on the etherification of glycerol with 1-butene or $\mathrm{C}_{3} \mathrm{H}_{6}$ with addition of an acidic heterogeneous catalyst (that included amberlyst-15, S100, and S200 resins) for synthesis of butyl glycerol ethers (BGEs) or propyl glycerol ethers (PGEs), respectively. When blended with palm oil derived diesel, BGEs and PGEs can be used to reduce the cloud point, thus, improving flow capacity of diesel fuel and increasing the life spans of fuel filters and injectors in engines.

\section{Conclusions}

Different types of liquid biofuels (i.e., bioethanol, biomethanol, biobutanol, bio-ammonia, biokerosene, and bioglycerol) that could be produced by microbial processes including their advantages and disadvantages from fuel properties perspective have been comprehensively reviewed in this article. In order to understand the mechanisms behind each biochemical process, the fuelgenerating microorganisms, different biological pathways, some main influential parameters on microbial biofuel production, as well as deficiencies and limitations of microbial-based processes have also been scrutinized.

Currently, ethanol (143 billion liters produced in 2017) is the world largest biofuel consumed, $80 \%$ of which is produced by fermentation. The application of bioethanol as fuel extender is popular and many countries support blending gasoline with ethanol up to $10 \%$, v/v. On the dark side, the world top two bioethanol producing countries, i.e., the USA and Brazil, accounting for more than $85 \%$ of the total amount of bioethanol produced globally from 2007 to 2015 utilize corn and sugarcane, respectively. The application of these food commodities could nullify the advantages of using bioethanol and in some cases, could even have negative consequences. To address this concern, lignocellulosic feedstocks should be more seriously exploited. In fact, there is mature knowledge and technology for lignocellulose-based bioethanol production but some economic constraints on the way of its global commercialization must first be resolved.

Butanol is the best liquid microbial biofuel for substituting gasoline and diesel with respect to fuel characteristics, i.e., energy content, hydrophobicity, flash point, low volatility, miscibility, and octane-enhancement property, greater heat of evaporation, and reduced $\mathrm{NO}_{\mathrm{X}}$ emissions. However, compared to bioethanol, 8-18 times lower concentrations of biobutanol could be reached during fermentation limiting its application as biofuel. The commercialization of biobutanol has been significantly improved by metabolic engineering techniques. Sustainable biobutanol production from non-food substrates, increasing tolerance to biobutanol titer in biobutanol-producting microorganisms, and enhancing biobutanol recovery from fermentation broth, are among the major challenges to overcome to pave the way for economically viable commercialization of this green fuel.

Methanol is also a good fuel extender, and it can be produced from $\mathrm{CH}_{4}$ conversion by some microorganisms. Therefore, anaerobic digestion process may be coupled with the methanol industry to convert the raw biogas generated into methanol, which is a better transportation fuel than $\mathrm{CH}_{4}$. For a successful biomethanol production, the microorganisms involved should be engineered by manipulating their MDH enzyme while electron donors such as formate should also be provided to enhance methanol accumulation in bioreactors and prevent the oxidation of produced methanol to $\mathrm{CO}_{2}$ by methanotrophs. However, despite some achievements, the current commercial microbial production of methanol is not yet profitable.

Microorganisms could also contribute to bio-jet fuel production from various feedstocks (sugar, starch, and lignocellulose) via different technologies such as DSHC, AtJ, and Bio-GtL. Among these processes, DSHC has already reached the demo-plant stage and has the most complex process with high overall efficiency of up to $97 \%$. Intriguingly, despite lower additives requirement such as $\mathrm{H}_{2}$ by DSHC and AtJ processes, BioGtL could be conducted at relatively lower costs. The kerosene yield of DSHC, AtJ, Bio-GtL techniques stands at $97 \%, 48 \%$, and $50-60 \%$ the last two techniques are still in at $R \& D$ stage though.

The production of $\mathrm{NH}_{3}$ through microbial processes is also well-known; however, its application as biofuel still requires further development of specifically designed ICEs. The other impediment on the way of $\mathrm{NH}_{3}$ application as biofuel is the concern that owing to the main application of $\mathrm{NH}_{3}$ as biofertilizer (source of nitrogen), such an approach could result in adverse consequences to the agricultural sector. In contrast to ammonia, the interest for microbial production of glycerol has declined since 2001 due to the rapidly growing biodiesel industry, delivering ample amounts of glycerol as co-product. Moreover, it is not possible to burn glycerol directly in ICEs but recently, efforts are directed toward its conversion into some promising fuel additives.

It should also be highlighted that desired characteristics for production of biofuels and precursors of interest could be effectively conferred to appropriate microorganisms via rapid, rational, and extremely powerful metabolic engineering techniques, i.e., by introducing entire new pathways or modifying existing ones. This allows the development of superior microbial cell factories, required for commercialization of biofuels. For instance, modified microorganisms could assimilate new substrates, which could not be previously degraded by them, subsequently increasing the economic profitability of the microbial biofuel production systems. In addition to technological developments to improve microbial biofuels production, development of coherent social and environmentally compatible strategies and framework policies that result in reductions in fossil fuel subsidies in favor of biofuels could play a substantial role in increasing investments in these green energy carriers

Overall, it could be concluded that microbial biofuels production under the biorefinery scheme employing waste-to-biofuel technologies as well as the subsequent conversion of the generated biofuels into various fue additives as value-added products could be a promising solution to boost the global economy and mitigate climate change simultaneously.

\section{References}

[1] Abedinifar, S., Karimi, K., Khanahmadi, M., Taherzadeh, M.J., 2009. Ethanol production by Mucor indicus and Rhizopus oryzae from rice straw by separate hydrolysis and fermentation. Biomass Bioenergy 33(5), 828-833.

[2] AFDC, 2018. Energy efficiency and renewable energy. Alternative Fuel Data Center, U.S. Department of Energy. (accessed on 21 Aug. 2019).

[3] Aghbashlo, M., Tabatabaei, M., Khalife, E., Shojaei, T.R., Dadak, A., 2018. Exergoeconomic analysis of a DI diesel engine fueled with diesel/biodiesel (B5) emulsions containing aqueous nano cerium oxide. Energy 149, 967-978

[4] Agrawal, M., Mao, Z., Chen, R.R., 2011. Adaptation yields a highly efficient xylose-fermenting Zymomonas mobilis strain. Biotechnol. Bioeng. 108(4), 777-785.

[5] Alaska Airlines, 2016. Alaska Airlines flies first commercial flight with new biofuel made from forest residuals. (accessed on 17 Sep. 2019).

[6] Alia, K.B., Rasul, I., Azeem, F., Hussain, S., Siddique, M.H., Muzammil, S., Riaz, M., Bari, A., Liaqat, S., Nadeem, H., 2019. Microbial production of ethanol, in: Inamuddin, M.F.A., Asiri, 
A.M. (Eds.), Microbial Fuel Cells: Materials and Applications. Materials Research Forum LLC., Pennsylvania, pp. 307-334.

[7] Amine, M., Awad, E.N., Ibrahim, V., Barakat, Y., 2018. Effect of ethyl acetate addition on phase stability, octane number and volatility criteria of ethanol-gasoline blends. Egypt. J. Pet. 27(4), 567-572.

[8] Amine, M., Zahran, M., Awad, E., El-Zein, S., Barakat, Y., 2013. Volatility criteria and specifications of some gasoline-ester blends. Inter. J. Mod. Org. Chem. 2, 226-250.

[9] Amini, H., Sowlat, M.H., 2014. National and sub-national environmental burden of disease in Iran from 1990 to 2013-study profile. Arch. Iran. Med. 17(1), 62.

[10] Aminifarshidmehr, N., 1996. The management of chronic suppurative otitis media with acid media solution. Am. J. Otol. 17(1), 24-25.

[11] Annous, B.A., Blaschek, H.P., 1991. Isolation and characterization of Clostridium acetobutylicum mutants with enhanced amylolytic activity. Appl. Microbiol. Biotechnol. 57(9), 2544-2548.

[12] Anthony, C., 1992. The c-type cytochromes of methylotrophic bacteria. Biochim. Biophys. Acta. 1099(1), 1-15.

[13] Arteconi, A., Mazzarini, A., Di Nicola, G., 2011. Emissions from ethers and organic carbonate fuel additives: a review. Water, Air, Soil Pollut. 221(1-4), 405.

[14] Atsumi, S., Cann, A.F., Connor, M.R., Shen, C.R., Smith, K.M., Brynildsen, M.P., Chou, K.J., Hanai, T., Liao, J.C., 2008a. Metabolic engineering of Escherichia coli for 1-butanol production. Metab. Eng. 10(6), 305-311.

[15] Atsumi, S., Hanai, T., Liao, J.C., 2008b. Non-fermentative pathways for synthesis of branched-chain higher alcohols as biofuels. Nature 451(7174), 86

[16] Azimi, H., Tezel, H., Thibault, J., 2019. Optimisation of the in-situ recovery of butanol from $\mathrm{ABE}$ fermentation broth via membrane pervaporation. Chem. Eng. Res. Des. 150, 49-64.

[17] Babau, M., Cescut, J., Allouche, Y., Lombaert-Valot, I., Fillaudeau, L., Uribelarrea, J., Molina-Jouve, C., 2013. Towards a microbial production of fatty acids as precursors of biokerosene from glucose and xylose. Oil Gas Sci. Technol. 68(5), 899-911.

[18] Babson, D.M., Bellman, K., Prakash, S., Fennell, D.E., 2013. Anaerobic digestion for methane generation and ammonia reforming for hydrogen production: A thermodynamic energy balance of a model system to demonstrate net energy feasibility. Biomass Bioenergy. 56, 493-505.

[19] Baer, S.H., Blaschek, H.P., Smith, T.L., 1987. Effect of butanol challenge and temperature on lipid composition and membrane fluidity of butanol-tolerant Clostridium acetobutylicum. Appl. Microbiol. Biotechnol. 53(12), 2854-2861.

[20] Baere, L., Mattheeuws, B., 2010. Anaerobic digestion of MSW in Europe. BioCycle 51(2), 24-26.

[21] Balat, M., Balat, H., Öz, C., 2008. Progress in bioethanol processing. Prog. Energy. Combust. Sci. 34(5), 551-573.

[22] Ball, K.F., Bostick, J.G., Brennan, T.J., 1999. Fuel lubricity from blends of a diethanolamine derivative and biodiesel. United States Patent US5891203 A.

[23] Beal, E.J., House, C.H., Orphan, V.J., 2009. Manganese-and irondependent marine methane oxidation. Science 325(5937), 184-187.

[24] Bechtold, R., 1997. Alternative fuels for vehicle fleet demonstration program. Report of the New York State Energy Research and Development Authority, NYSERDA Report.

[25] Bermejo, L.L., Welker, N.E., Papoutsakis, E.T., 1998. Expression of Clostridium acetobutylicum atcc 824 genes in Escherichia coli for acetone production and acetate detoxification. Appl. Microbiol. Biotechnol. 64(3), 1079-1085.

[26] Bertilsson, M., Olofsson, K., Lidén, G., 2009. Prefermentation improves xylose utilization in simultaneous saccharification and cofermentation of pretreated spruce. Biotechnol. Biofuels 2(1), 8 .

[27] Bjerre, A.B., Olesen, A.B., Fernqvist, T., Plöger, A., Schmidt, A.S., 1996. Pretreatment of wheat straw using combined wet oxidation and alkaline hydrolysis resulting in convertible cellulose and hemicellulose. Biotechnol. Bioeng. 49(5), 568-577.

[28] Boetius, A., Ravenschlag, K., Schubert, C.J., Rickert, D., 2000. A marine microbial consortium apparently mediating anaerobic oxidation of methane. Nature 407(6804), 623.
[29] Borden, J.R., Papoutsakis, E.T., 2007. Dynamics of genomic library enrichment and identification of solvent tolerance genes for Clostridium acetobutylicum. Appl. Microbiol. Biotechnol. 73(9), 3061-3068.

[30] Borodina, I., Nielsen, J., 2014. Advances in metabolic engineering of yeast Saccharomyces cerevisiae for production of chemicals. Biotechnol. J. 9(5), 609-620.

[31] Brady, S., Tam, K., Leung, C., Salam, C., 2008. Zero waste biodiesel: Using glycerin and biomass to create renewable energy. UCR Undergrad. Res. J. 2, 5-11,

[32] Brandhorst, H., Baltazar-Lopez, M., Tatarchuk, B., Cahela, D.R., Barron, T., 2008. Ammonia-its transformation and effective utilization. 6th International Energy Conversion Engineering Conference (IECEC). AIAA 2008-5610.

[33] Breitmaier, E., Jung, G., 2005. Organische Chemie. Grundlagen, Stoffklassen, Reaktionen, Konzepte, Molekülstruktur; zahlreiche Formeln, Tabellen, 5., überarb. Aufl. Thieme, Stuttgart.

[34] Brooks, T.A., Ingram, L., 1995. Conversion of mixed waste office paper to ethanol by genetically engineered Klebsiella oxytoca strain P2. Biotechnol. Prog. 11(6), 619-625.

[35] Burger, J., Siegert, M., Ströfer, E., Hasse, H., 2010. Poly (oxymethylene) dimethyl ethers as components of tailored diesel fuel: Properties, synthesis and purification concepts. Fuel 89(11), 3315-3319.

[36] Butler, J.R., Pelati, J.E., 2010. Method for production of styrene from toluene and methanol. European Patent, EP2370378A1.

[37] Cáceres, M., Gentina, J.C., Aroca, G., 2014. Oxidation of methane by Methylomicrobium album and Methylocystis sp. in the presence of H2S and NH3. Biotechnol. Lett. 36(1), 69-74.

[38] Chan, S.I., Nguyen, H.H.T., Chen, K.H., Yu, S.S., 2011. Overexpression and purification of the particulate methane monooxygenase from Methylococcus capsulatus (Bath). Methods Enzymol. 495, 177.

[39] Chen, G., Li, S., Jiao, F., Yuan, Q., 2007. Catalytic dehydration of bioethanol to ethylene over $\mathrm{TiO}_{2} / \gamma-\mathrm{Al}_{2} \mathrm{O}_{3}$ catalysts in microchannel reactors. Catal. Today 125(1), 111-119.

[40] Cheng, W.H., Kung, H.H., 1994. Methanol production and use. Marcel Dekker, New York.

[41] Choudhary, T.V., Choudhary, V.R., 2008. Energy-efficient syngas production through catalytic oxy-methane reforming reactions. Angew. Chem., Int. Ed. 47(10), 1828-1847.

[42] Christensen, C.H., Johannessen, T., Sørensen, R.Z., Nørskov, J.K., 2006. Towards an ammonia-mediated hydrogen economy? Catal. Today 111(1), 140-144.

[43] Colby, J., Stirling, D.I., Dalton, H., 1977. The soluble methane mono-oxygenase of Methylococcus capsulatus (Bath). Its ability to oxygenate $\mathrm{n}$-alkanes, $\mathrm{n}$-alkenes, ethers, and alicyclic, aromatic and heterocyclic compounds. Biochem. J. 165(2), 395-402.

[44] Cotton, A.F., Wilkinson, G., Bochmann, M., Murillo, C.A., 1999. Advanced inorganic chemistry. John Wiley and Sons, USA.

[45] Cox, J.M., Day, D.J., Anthony, C., 1992. The interaction of methanol dehydrogenase and its electron acceptor, cytochrome $\mathrm{c}_{\mathrm{L}}$, in the facultative methylotroph Methylobacterium extorquens AM1 and in the obligate methylotroph Methylophilus methylotrophus. Biochim. Biophys. Acta 1119(1), 97-106.

[46] Criddle, C.S., Hart, J.R., Wu, W.M., Sundstrom, E.R., Morse, M.C., Billington, S.L., Rostkowski, K.H., Frank, C.W., 2012. Production of PHA using biogas as feedstock and power source. United State Patent US20130071890A1.

[47] Cummins, L., 1989. Internal Fire. Revised ed. Society of Automotive Engineers, Incorporated, Warrendale, Pennsylvania.

[48] Dabbagh, H., Ghobadi, F., Ehsani, M., Moradmand, M., 2013. The influence of ester additives on the properties of gasoline. Fuel 104, 216-223.

[49] De Klerk, A., 2012. Fischer-Tropsch Refining. John Wiley and Sons, Weinheim, Hoboken, New Jersey.

[50] De Torres, M., Jimenez-Oses, G., Mayoral, J.A., Pires, E., de los Santos, M., 2012. Glycerol ketals: Synthesis and profits in biodiesel blends. Fuel 94, 614-616. 
[51] Dedysh, S.N., Dunfield, P.F., 2011. Facultative and obligate methanotrophs: How to identify and differentiate them. Methods Enzymol. 495, 31

[52] Dedysh, S.N., Knief, C., Dunfield, P.F., 2005. Methylocella species are facultatively methanotrophic. J. Bacteriol. 187(13), 4665-4670.

[53] Dehghani, A., Ranjbar, M., Eliassi, A., 2018. Novel porous iron molybdate catalysts for synthesis of dimethoxymethane from methanol: Metal organic frameworks as precursors. Nanochem. Res. 3(1), 50-61.

[54] Dehhaghi, M., Kazemi Shariat Panahi, H., Guillemin, G.J., 2019. Microorganisms, tryptophan metabolism, and kynurenine pathway: A complex interconnected loop influencing human health status. Int. J. Tryptophan Res. 12, 1-10.

[55] Dehhaghi, M., Kazemi Shariat Panahi, H., Guillemin, G.J., 2018a. Microorganisms' footprint in neurodegenerative diseases. Front. Cell. Neurosci. 12, 466.

[56] Dehhaghi, M., Mohammadipanah, F., 2017. Evaluation of growth inhibition activity of myxobacterial extracts against multi-drug resistant Acinetobacter baumannii. Prog. Biol. Sci. 6(2), 181-187.

[57] Dehhaghi, M., Mohammadipanah, F., Guillemin, G.J., 2018 b. Myxobacterial natural products: An under-valued source of products for drug discovery for neurological disorders. Neurotoxicology 66, 195-203

[58] DeRosa, T.F., 2012. Next generation of international chemical additives: A critical review of current US patents. Elsevier, United Kingdom.

[59] Dias De Oliveira, M.E., Vaughan, B.E., Rykiel, E.J., 2005. Ethanol as fuel: Energy, carbon dioxide balances, and ecological footprint. AIBS Bull. 55(7), 593-602.

[60] Dien, B., Cotta, M., Jeffries, T., 2003. Bacteria engineered for fuel ethanol production: Current status. Appl. Microbiol. Biotechnol. 63(3), 258-266

[61] Dong, J.J., Han, R.Z., Xu, G.C., Gong, L., Xing, W.R., Ni, Y., 2018. Detoxification of furfural residues hydrolysate for butanol fermentation by Clostridium saccharobutylicum DSM 13864. Bioresour. Technol. 259, 40-45.

[62] Doran-Peterson, J., Cook, D.M., Brandon, S.K., 2008. Microbial conversion of sugars from plant biomass to lactic acid or ethanol. Plant J. 54(4), 582-592.

[63] Dunfield, P.F., Belova, S.E., Vorob'ev, A.V., Cornish, S.L., Dedysh, S.N., 2010. Methylocapsa aurea sp. nov., a facultative methanotroph possessing a particulate methane monooxygenase, and emended description of the genus Methylocapsa. Int. J. Syst. Evol. Microbiol. 60(11), 2659-2664.

[64] Dürre, P., 2005. Sporulation in clostridia (genetics), in: Dürre P. (Ed.), Handbook on clostridia. CRC Press, Boca Raton, Florida, pp. 659-666.

[65] Energy Information Administration, 1988. Alternative to traditional transportation fuels. DOE/EIA-0585(98). Washington, DC

[66] Errico, M., Sotoft, L.F., Nielsen, A.K., Norddahl, B., 2018. Treatment costs of ammonia recovery from biogas digestate by air stripping analyzed by process simulation. Clean Technol. Environ. Policy 20(7), $1479-1489$.

[67] Ettwig, K.F., Butler, M.K., Le Paslier, D., Pelletier, E., Mangenot, S., Kuypers, M.M., Schreiber, F., Dutilh, B.E., Zedelius, J., De Beer, D., 2010. Nitrite-driven anaerobic methane oxidation by oxygenic bacteria. Nature 464(7288), 543

[68] Ezeji, T., Milne, C., Price, N.D., Blaschek, H.P., 2010. Achievements and perspectives to overcome the poor solvent resistance in acetone and butanol-producing microorganisms. Appl. Microbiol. Biotechnol. 85(6), 1697-1712.

[69] Ezeji, T., Qureshi, N., Blaschek, H.P., 2007. Butanol production from agricultural residues: impact of degradation products on Clostridium beijerinckii growth and butanol fermentation. Biotechnol. Bioeng. 97(6), 1460-1469

[70] Ezeldin, M., Masaad, A.M., Suleman, N.M., 2015. Effect of diethylamine on physicochemical properties of reformat gasoline. Am. J. Sci. Res. (106), 88-96.

[71] Feibelman, P.J., Stumpf, R., 2006. Comments on potential roles of ammonia in a hydrogen economy - a study of issues related to the use of ammonia for on-board vehicular hydrogen storage. Sandia Natl. Lab.

[72] Fernando, S., Adhikari, S., Kota, K., Bandi, R., 2007. Glycerol based automotive fuels from future biorefineries. Fuel 86(17), 2806-2809.

[73] Fiedler, E., Grossmann, G., Kersebohm, D.B., Weiss, G., Witte, C., 2003. Methanol. Ullmann's Encyclopedia of Industrial Chemistry. 6th ed. Wiley-VCH GmbH, Weinheim.

[74] Françoisse, O., Thyrion, F., 1991. Kinetics and mechanism of ethyl tert-butyl ether liquid-phase synthesis. Chem. Eng. Process 30(3), 141-149.

[75] Frank, J., Krimpen, S.H., Verwiel, P.E.J., Jongejan, J.A., Mulder, A.C., Duine, J.A., 1989. On the mechanism of inhibition of methanol dehydrogenase by cyclopropane-derived inhibitors. Eur. J. Biochem. 184(1), 187-195.

[76] Foulquier, C., Huang, C.-N., Thiel, A., Wilding-Steel, T., Soula, J., Yoo, M., Ehrenreich, A., Meynial-Salles, I., Liebl, W., Soucaille, P., 2019. An efficient method for markerless mutant generation by allelic exchange in Clostridium acetobutylicum and Clostridium saccharobutylicum using suicide vectors. Biotechnol. Biofuels 12(1), 31

[77] Gapes, J., 2000. The economics of acetone-butanol fermentation: Theoretical and market considerations. J. Mol. Microbiol. Biotechnol. 2(1), 27-32.

[78] Ge, X., Yang, L., Sheets, J.P., Yu, Z., Li, Y., 2014. Biological conversion of methane to liquid fuels: status and opportunities. Biotechnol. Adv. 32(8), 1460-1475.

[79] Gevo Inc., 2016. Gevo's alcohol to jet fuel meets approved ASTM standard. Clears key hurdle to flying first commercial test flight with Alaska airlines. (accessed on 12 Sep. 2019).

[80] Gómez Cuenca, F., Gómez Marín, M., Folgueras Díaz, M.B., 2011 Effects of ethylene glycol ethers on diesel fuel properties and emissions in a diesel engine. Energy Convers. Manage. 52(8), 3027-3033

[81] Green, E.M., Boynton, Z.L., Harris, L.M., Rudolph, F.B. Papoutsakis, E.T., Bennett, G.N., 1996. Genetic manipulation of acid formation pathways by gene inactivation in Clostridium acetobutylicum ATCC 824. Microbiology 142(8), 2079-2086.

[82] Greene, N., 2004. Growing energy. How biofuels can help end America's oil dependence. Natural Resources Defense Council.

[83] Gunasekaran, P., Raj, K.C., 1999. Ethanol fermentation technology-Zymomonas mobilis. Curr. Sci. 77(1), 56-68.

[84] Gupta, R., Sharma, K.K., Kuhad, R.C., 2009. Separate hydrolysis and fermentation (SHF) of Prosopis juliflora, a woody substrate, for the production of cellulosic ethanol by Saccharomyces cerevisiae and Pichia stipitis-NCIM 3498. Bioresour. Technol. 100(3), 1214-1220.

[85] Hahn-Hägerdal, B., Galbe, M., Gorwa-Grauslund, M.F., Lidén, G., Zacchi, G., 2006. Bio-ethanol-the fuel of tomorrow from the residues of today. Trends Biotechnol. 24(12), 549-556.

[86] Hajjari, M., Tabatabaei, M., Aghbashlo, M., Ghanavati, H., 2017 A review on the prospects of sustainable biodiesel production: A global scenario with an emphasis on waste-oil biodiesel utilization. Renewable Sustainable Energy Rev. 72, 445-464.

[87] Hal, B., William, K., Scott, S., 1982. The forbidden fuel: Power alcohol in the twentieth century. Boyd Griffin, New York.

[88] Hamedi, J., Dehhaghi, M., Mohammdipanah, F., 2015a. Isolation of extremely heavy metal resistant strains of rare actinomycetes from high metal content soils in Iran. Int. J. Environ. Res. 9(2), 475-480.

[89] Hamedi, J., Mohammadipanah, F., Panahi, H.K.S., 2015b. Biotechnological exploitation of Actinobacterial members. in: Maheshwari, D., Saraf, M. (Eds.), Halophiles. Vol. 7, Springer, Cham, pp. 57-143.

[90] Hamelinck, C.N., Van Hooijdonk, G., Faaij, A.P., 2005. Ethanol from lignocellulosic biomass: techno-economic performance in short-, middle-and long-term. Biomass Bioenergy 28(4), 384-410.

[91] Han, B., Su, T., Wu, H., Gou, Z., Xing, X.H., Jiang, H., Chen, Y., Li, X., Murrell, J.C., 2009. Paraffin oil as a "methane vector" for rapid and high cell density cultivation of Methylosinu. 
trichosporium OB3b. Appl. Microbiol. Biotechnol. 83(4), 669-677.

[92] Han, J.S., Ahn, C.M., Mahanty, B., Kim, C.G., 2013. Partial oxidative conversion of methane to methanol through selective inhibition of methanol dehydrogenase in methanotrophic consortium from landfill cover soil. Appl. Biochem. Biotechnol. 171(6), 1487-1499.

[93] Hansen, J., 1997. Methanol synthesis, in: Ertl, G., Knozinger, H., Weitkamp, J. (Eds.), Handbook of heterogeneous catalysis. Vol. 4, Wiley-VCH GmbH, Weinheim, pp. 1856.

[94] Hanson, R.S., Hanson, T.E., 1996. Methanotrophic bacteria. Microbiol. Rev. 60(2), 439-471.

[95] Hardenberg, H.O., Morey, S., 1992. Samuel Morey and his atmospheric engine. Society of Automotive Engineers, Warrendale, Pennsylvania.

[96] Harris, L., Blank, L., Desai, R., Welker, N., Papoutsakis, E., 2001. Fermentation characterization and flux analysis of recombinant strains of Clostridium acetobutylicum with an inactivated solR gene. J. Ind. Microbiol. Biotechnol. 27(5), 322-328.

[97] Harvey, B.G., 2016. High density fuels from isoprene. United State Patent US9371258 B1.

[98] Haynes, C.A., Gonzalez, R., 2014. Rethinking biological activation of methane and conversion to liquid fuels. Nat. Chem. Biol. 10(5), 331339.

[99] Hester, A., 2000. Microbial glycerol. Ind. Bioprocess 22(4), 3-5.

[100] Ho, M.W., 2005. Biogas bonanza for third world development. Institute of Science in Society, London, UK.

[101] Holbrook, E., 2018. Demand for jet fuel skyrockets, efficiency gains to follow. Energy Manager Today.

[102] Holbroock, J., 2007. Wrap-up/Ammonia and the clean energy portfolio. Proceedings of the Ammonia-Sustainable, Emission Free Fuel Conference, October 15-16, San Francisco, CA. Iowa Energy Center.

[103] Holmgren, J., 2013. Innovative use of industrial waste gases to produce sustainable fuels and chemicals. Presentation held at the Avalon Air Show, Geelong, Australia Google Scholar.

[104] Huang, C.N., Liebl, W., Ehrenreich, A., 2018. Restriction-deficient mutants and marker-less genomic modification for metabolic engineering of the solvent producer Clostridium saccharobutylicum. Biotechnol. Biofuels 11(1), 264

[105] Hull, A., 2012. Technology for the production of fully synthetic aviation fuels, diesel and gasoline. Contribution to Solakonferansen. Stavanger.

[106] Huntsman., 2017. Dimethylaminopropylamine (DMAPA). Technical Bulletin, Huntsman Advanced Technology Center, Huntsman Corporation.

[107] Inui, M., Suda, M., Kimura, S., Yasuda, K., Suzuki, H., Toda, H., Yamamoto, S., Okino, S., Suzuki, N., Yukawa, H., 2008. Expression of Clostridium acetobutylicum butanol synthetic genes in Escherichia coli. Appl. Microbiol. Biotechnol. 77(6), 1305-1316.

[108] James, D.D., Moghaddam, R.B., Chen, B., Pickup, P.G., 2018. Ruthenium-tin oxide/carbon supported platinum catalysts for electrochemical oxidation of ethanol in direct ethanol fuel cells. J. Electrochem. Soc. 165(3), F215-F219.

[109] Jeffries, T., Jin, Y., 2004. Metabolic engineering for improved fermentation of pentoses by yeasts. Appl. Microbiol. Biotechnol. 63(5), 495-509.

[110] Jensen, J.O., Vestb $\varnothing$, A.P., Li, Q., Bjerrum, N., 2007. The energy efficiency of onboard hydrogen storage. J. Alloys Compd. 446, 723728.

[111] Jiang, A., Zhang, T., Zhao, Q., Frear, C., Chen, S., 2010. Integrated ammonia recovery technology in conjunction with dairy anaerobic digestion. Climate Friendly Farming, Washington State University.

[112] Jiménez-Bonilla, P., Wang, Y., 2018. In situ biobutanol recovery from clostridial fermentations: a critical review. Crit. Rev. Biotechnol. 38(3), 469-482.

[113] Jingura, R.M., Kamusoko, R., 2017. Methods for determination of biomethane potential of feedstocks: A review. Biofuel Res. J. 4(2), $573-586$

[114] Joachimsthal, E.L., Rogers, P.L., 2000. Characterization of a highproductivity recombinant strain of Zymomonas mobilis for ethanol production from glucose/xylose mixtures. Appl. Biochem. Biotechnol. 84(1-9), 343-356.

[115] Johnston, G., 2013. Alcohol to jet (AtJ). Contribution to Paris Air Show. June 2013, Paris

[116] Jones, R., 2011. Ethyl acetate as fuel or fuel additive. United State Patent US20110296744A1.

[117] Joshi, B., Joshi, J., Bhattarai, T., Sreerama, L., 2019. Currently used microbes and advantages of using genetically modified microbes for ethanol production. in: Ray, C.R., Ramachandran, S (Eds.), Bioethanol Production from Food Crops. Elsevier, pp. $293-$ 316.

[118] Jung, A.K., Voelkel, L., Crema, S., Misske, A., 2016. Composition and method to improve the fuel economy of hydrocarbon fueled internal combustion engines. United States Patent US9447351B2.

[119] Kádár， Z., Szengyel, Z., Réczey, K., 2004. Simultaneous saccharification and fermentation (SSF) of industrial wastes for the production of ethanol. Ind. Crops Prod. 20(1), 103-110.

[120] Kagyrmanova, A., Chumachenko, V., Korotkikh, V., Kashkin, V., Noskov, A., 2011. Catalytic dehydration of bioethanol to ethylene: Pilot-scale studies and process simulation. Chem. Eng. J. 176, 188 194.

[121] Karas, L., Piel, W.J., 2005. Ethers. Fifth ed. Kirk-Othmer Encyclopedia of Chemical Technology, Vol. 10.

[122] Karimi, K., Emtiazi, G., Taherzadeh, M.J., 2006. Ethanol production from dilute-acid pretreated rice straw by simultaneous saccharification and fermentation with Mucor indicus, Rhizopus oryzae, and Saccharomyces cerevisiae. Enzyme Microb. Technol. 40(1), 138-144

[123] Katahira, S., Mizuike, A., Fukuda, H., Kondo, A., 2006. Ethanol fermentation from lignocellulosic hydrolysate by a recombinant xylose-and cellooligosaccharide-assimilating yeast strain. Appl. Microbiol. Biotechnol. 72(6), 1136-1143

[124] Kazemi Shariat Panahi, H., Dehhaghi, M., Aghbashlo, M., Karimi, K., Tabatabaei, M., 2019a. Conversion of residues from agro-food industry into bioethanol in Iran: An under-valued biofuel additive to phase out MTBE in gasoline. Renewable Energy 145, 699-710.

[125] Kazemi Shariat Panahi, H., Dehhaghi, M., Aghbashlo, M., Karimi, K., Tabatabaei, M, 2019b. Shifting fuel feedstock from oil wells to sea: Iran outlook and potential for biofuel production from brown macroalgae (ochrophyta; phaeophyceae). Renewable Sustainable Energy Rev. 112, 626-642.

[126] Kazemi Shariat Panahi, H., Tabatabaei, M., Aghbashlo, M., Dehhaghi, M., Rehan, M., Nizami, A.S., 2019c. Recent updates on the production and upgrading of bio-crude oil from microalgae. Bioresour. Technol. Rep. 7, 100216.

[127] Kochloefl, K., 1997. Steam reforming, in: Ertl G., Knozinger, H., Weitkamp, J. (Eds.), Handbook of heterogeneous catalysis. Vol. 4, Wiley-VCH GmbH. Weinheim, pp. 1819.

[128] Koehl, W.J., Benson, J.D., Burns, V.R., Gorse, R.A., Hochhauser, A.M., Knepper, J.C., Leppard, W.R., Painter, L.J., Rapp, L.A., Reuter, R.M., 1993. Comparison of effects of MTBE and TAME on exhaust and evaporative emissions-Auto/oil air quality improvement research program. SAE Technical Paper. 0148-7191.

[129] Koehler, D., Claffey, W., 1999. Polymeric-amine fuel and lubricant additive. United State Patent US5962738A.

[130] Koppram, R., Nielsen, F., Albers, E., Lambert, A., Wännström, S., Welin, L., Zacchi, G., Olsson, L., 2013. Simultaneous saccharification and co-fermentation for bioethanol production using corncobs at lab, PDU and demo scales. Biotechnol. Biofuels 6(1), 2.

[131] Kroch, E., 1945. Ammonia-a fuel for motor buses. J. Inst. Pet. 31, 213-223.

[132] Kumar, A., Singh, J., Baskar, C., 2019. Lignocellulosic biomass for bioethanol production through microbes: Strategies to improve process efficiency. in: Rastegari, A.A., Yadav, A.N., Gupta, A. (Eds.), Prospects of renewable bioprocessing in future energy systems. Springer, pp. 357-386.

[133] Lagona, J.A., Loper, J.T., 2017. Lubricating oil composition and additive therefor having improved wear properties. United States Patent US9574158B2. 
[134] LaMonica, M., 2012. Natural gas tapped as bridge to biofuels, MIT Technology Review. (accessed on 12 Sep. 2018).

[135] Lamy, C., Coutanceau, C., 2012. Electrocatalysis of alcohol oxidation reactions at platinum group metals, in: Liang, Z.X., Zhao, T.S. (Eds.), Catalysts for alcohol-fuelled direct oxidation fuel cells. Royal Society of Chemistry. Cambridge, United Kingdom.

[136] Lancet., 2016. Air pollution-crossing borders. Lancet 388.

[137] Lapuerta, M., Rodríguez-Fernández, J., García-Contreras, R., 2015. Effect of a glycerol-derived advanced biofuel-FAGE (fatty acid formal glycerol ester)-on the emissions of a diesel engine tested under the New European Driving Cycle. Energy 93, 568-579.

[138] Latvala, V., Ketola, A., Oskanen, I., Koskenniemi, K., Laaksonen, M., Lensu, E., 2014. Method for producing ammonia or ammonium by fermentation. United States Patent, Application No.14/565,055.

[139] Lee, S.Y., Park, J.H., Jang, S.H., Nielsen, L.K., Kim, J., Jung, K.S., 2008. Fermentative butanol production by clostridia. Biotechnol. Bioeng. 101(2), 209-228.

[140] Levine, J.A., Wu, S., Chasan, D.E., Rabbat, P., Fenton, R.J., Phillips, G.C., 2018. Friction-reducing compound, method of producing same, and lubricant composition. United States Patent US20170321147A1.

[141] Li, J., Feaster, S., Kohler, A., 2019. A multi-objective multitechnology (MOMT) evaluation and analysis framework for ammonia synthesis process development. Comput.-Aided Chem. Eng. 47, 415420.

[142] Lin, Y.L., Blaschek, H.P., 1983. Butanol production by a butanoltolerant strain of Clostridium acetobutylicum in extruded corn broth. Appl. Environ. Microbiol. 45(3), 966-973.

[143] Liu, Z.H., Chen, H.Z., 2016. Simultaneous saccharification and cofermentation for improving the xylose utilization of steam exploded corn stover at high solid loading. Bioresour. Technol. 201, 15-26.

[144] Lü, X.C., Yang, J.G., Zhang, W.G., Huang, Z., 2005. Improving the combustion and emissions of direct injection compression ignition engines using oxygenated fuel additives combined with a cetane number improver. Energy Fuels 19(5), 1879-1888.

[145] McDonald, R.C., Hamdan, M., 2019. Compact Direct Methanol Fuel Cell: Design Approach Using Commercial Micropumps. J. Electrochem. Energy Convers. Storage 16(1), 011003.

[146] MacLean, H.L., Lave, L.B., 2003. Evaluating automobile fuel/propulsion system technologies. Prog. Energy Combust. Sci. 29(1), 1-69.

[147] Mangelsdorf, I., Boehncke, A., Könnecker, G., 2002. Diethylene glycol dimethyl ether. World Health Organization, Geneva.

[148] Mariano, A.P., Qureshi, N., Filho, R.M., Ezeji, T.C., 2011. Bioproduction of butanol in bioreactors: new insights from simultaneous in situ butanol recovery to eliminate product toxicity. Biotechnol. Bioeng. 108(8), 1757-1765.

[149] Mariano, A.P., Qureshi, N., Filho, R.M., Ezeji, T.C., 2012. Assessment of in situ butanol recovery by vacuum during acetone butanol ethanol (ABE) fermentation. J. Chem. Technol. Biotechnol. 87(3), 334-340.

[150] Matsushika, A., Inoue, H., Kodaki, T., Sawayama, S., 2009. Ethanol production from xylose in engineered Saccharomyces cerevisiae strains: current state and perspectives. Appl. Microbiol. Biotechnol. 84(1), 37-53

[151] Mavinic, D.S., Lobanov, S., Koch, F.A., Farhana, S., 2019. Process for removal or recovery of ammonium nitrogen from wastewater streams. United States Patent 20190062172A1.

[152] McGuinness, D.S., 2011. Olefin oligomerization via metallacycles: Dimerization, trimerization, tetramerization, and beyond. Chem. Rev. 111(3), 2321-2341.

[153] Mohammadipanah, F., Hamedi, J., Dehhaghi, M., 2015. Halophilic bacteria: Potentials and applications in biotechnology. in: Maheshwari, D., Saraf, M. (Eds.), Halophiles. Vol. 7, Springer, Cham, pp. 277-321.

[154] Meadows, C.W., Kang, A., Lee, T.S., 2018. Metabolic engineering for advanced biofuels production and recent advances toward commercialization. Biotechnol. J. 13(1), 1600433.

[155] Mohammadipanah, F., Panahi, H.K.S., Imanparast, F., Hamedi, J., 2016. Development of a reversed-phase liquid chromatographic assay for the quantification of total persipeptides in fermentation broth. Chromatographia 79(19-20), 1325-1332.
[156] Monbaliu, J.C.M., Winter, M., Chevalier, B., Schmidt, F., Jiang, Y., Hoogendoorn, R., Kousemaker, M.A., Stevens, C.V., 2011. Effective production of the biodiesel additive STBE by a continuous flow process. Bioresour. Technol. 102(19), 9304-9307.

[157] Montoya, D., Arévalo, C., Gonzales, S., Aristizabal, F., Schwarz, W.H., 2001. New solvent-producing Clostridium sp. strains, hydrolyzing a wide range of polysaccharides, are closely related to Clostridium butyricum. J. Ind. Microbiol. Biotechnol. 27(5), 329335.

[158] Morschbacker, A., 2009. Bio-ethanol based ethylene. J. Macromol. Sci., Polym. Rev. 49(2), 79-84.

[159] Mota, C.J., Da Silva, C.X., Rosenbach Jr, N., Costa, J., Da Silva, F.V., 2010. Glycerin derivatives as fuel additives: The addition of glycerol/acetone ketal (solketal) in gasolines. Energy Fuels 24(4), 2733-2736

[160] Naidoo, M., Tai, S.L., Harrison, S.T.L., 2018. Energy requirements for the in-situ recovery of biobutanol via gas stripping. Biochem. Eng. J. 139, 74-84.

[161] Nair, R.V., Green, E.M., Watson, D.E., Bennett, G.N., Papoutsakis, E.T., 1999. Regulation of the sol locus genes for butanol and acetone formation in Clostridium acetobutylicum ATCC 824 by a putative transcriptional repressor. J. Bacteriol. 181(1), 319-330.

[162] Neuling, U., Kaltschmitt, M., 2015. Conversion routes for production of biokerosene - status and assessment. Biomass Convers. Biorefin. 5(4), 367-385.

[163] News Release Lotus Engineering, 2008. Lotus researches cars running on $\mathrm{CO}_{2}$ - Exige 270E Tri-fuel is the next stage of Lotus engineering's long-term sustainable, Synthetic Alcohol Research.

[164] Ng, C.Y.C., Takahashi, K., Liu, Z., 2016. Isolation, characterization, and optimization of an aerobic butanol-producing bacterium from Singapore. Biotechnol. Appl. Biochem. 63(1), 8691

[165] Nibin, T., Sathiyagnanam, A., Sivaprakasam, S., Saravanan, C., 2005. Investigation on emission characteristics of a diesel engine using oxygenated fuel additive. IE (I) J. 86, 51-54.

[166] Nielsen, D.R., Leonard, E., Yoon, S.H., Tseng, H.C., Yuan, C., Prather, K.L.J., 2009. Engineering alternative butanol production platforms in heterologous bacteria. Metab. Eng. 11(4), 262-273.

[167] Noureddini, H., Dailey, W., Hunt, B., 1998. Production of ethers of glycerol from crude glycerol-the by-product of biodlesel production. Chem. Biomol. Eng. Res. 13,121-129.

[168] Novozhilov, V., Joseph, P., Ishiko, K., Shimada, T., Wang, H., Liu, J., 2011. Polymer combustion as a basis for hybrid propulsion: A comprehensive review and new numerical approaches. Energies 4(10), 1779-1839.

[169] Nowell, G.P., 1994. On the road with methanol: The present and future benefits of methanol fuel. Acurex Environmental Technical Report.

[170] O'rourke, C., Kavasmaneck, P., Uhl, R., 1981. Manufacture of nbutanol and 2-ethylhexanol by the rhodium oxo process and applications of the alcohols, in: Wickson, E.J. (Ed.), Monohydric alcohols, ACS Publications, Washington, D.C., pp. 71-85.

[171] Ogbu, I., Ajiwe, V., 2016. Fuel properties and their correlations with fatty acids structures of methyl-and butyl-esters of Afzelia africana, Cucurbita pepo and Hura crepitans seed oils. Waste Biomass Valorization 7(2), 373-381.

[172] Okonkwo, C., Azam, M., Ezeji, T., Qureshi, N., 2016. Enhancing ethanol production from cellulosic sugars using Scheffersomyces (Pichia) stipitis. Bioprocess Biosyst. Eng. 39(7), 1023-1032.

[173] Olah, G.A., Goeppert, A., Prakash, G.S., 2011. Beyond oil and gas: the methanol economy. 2nd Edition ed. Wiley-VCH, Weinheim.

[174] Olofsson, K., Palmqvist, B., Lidén, G., 2010. Improving simultaneous saccharification and co-fermentation of pretreated wheat straw using both enzyme and substrate feeding. Biotechnol. Biofuels 3(1), 17 .

[175] Oprescu, E.E., Dragomir, R.E., Radu, E., Radu, A., Velea, S., Bolocan, I., Stepan, E., Rosca, P., 2014. Performance and emission characteristics of diesel engine powered with diesel-glycerol derivatives blends. Fuel Process. Technol. 126, 460-468 
[176] Panahi, H.K.S., Mohammadipanah, F., Dehhaghi, M., 2016. Optimization of extraction conditions for liquid-liquid extraction of persipeptides from Streptomyces zagrosensis fermentation broth. Eur. Chem. Bull. 5, 408-415.

[177] Park, S., Shah, N.N., Taylor, R.T., Droege, M.W., 1992. Batch cultivation of Methylosinus trichosporium OB3b: II. Production of particulate methane monooxygenase. Biotechnol. Bioeng. 40(1), 151157.

[178] Pavlov, O., Karsakov, S., Pavlov, S.Y., 2011. A new technology for the production of isoprene from isobutene-containing $\mathrm{C} 4$ fractions and formaldehyde: Prospects for industrial reconstruction. Theor. Found. Chem. Eng. 45(4), 487-491.

[179] Pechstein, J., Neuling, U., Gebauer, J., Kaltschmitt, M., 2018. Alcoholto-Jet (AtJ), in: Kaltschmitt, M., Neuling, U. (Eds), Biokerosene. Springer, pp. 543-574.

[180] Peng, L., Chen, Y., 2011. Conversion of paper sludge to ethanol by separate hydrolysis and fermentation (SHF) using Saccharomyces cerevisiae. Biomass Bioenergy 35(4), 1600-1606.

[181] Perry, J.H., Perry, C.P., 1990. Methanol: Bridge to a renewable energy future. University Press of America, Lanham, Maryland.

[182] Qi, Z., Hui, W., Qin, Z.f., Wu, Z.W., Wu, J.B., Fan, W.B., Wang, J.G., 2011. Synthesis of polyoxymethylene dimethyl ethers from methanol and trioxymethylene with molecular sieves as catalysts. Ranliao Huaxue Xuebao 39(12), 918-923.

[183] Quispe, C.A., Coronado, C.J., Carvalho Jr, J.A., 2013. Glycerol: Production, consumption, prices, characterization and new trends in combustion. Renewable Sustainable Energy Rev. 27, 475-493.

[184] Qureshi, N., Blaschek, H., 2001. Recent advances in ABE fermentation: Hyper-butanol producing Clostridium beijerinckii BA101. J. Ind. Microbiol. Biotechnol. 27(5), 287-291.

[185] Qureshi, N., Maddox, I.S., Friedl, A., 1992. Application of continuous substrate feeding to the $\mathrm{ABE}$ fermentation: Relief of product inhibition using extraction, perstraction, stripping, and pervaporation. Biotechnol. Prog. 8(5), 382-390.

[186] Raganati, F., Procentese, A., Olivieri, G., Russo, M.E., Salatino, P., Marzocchella, A., 2018. Bio-butanol separation by adsorption on various materials: Assessment of isotherms and effects of other ABEfermentation compounds. Sep. Purif. Technol. 191, 328-339.

[187] Rahimpour, M.R., Keshtkari, S., Aryafard, E., 2019. Ethanol for Air Transportation, in: Basile, A., Iulianelli, A., Dalena, F., Nejat, T.V. (Eds.), Ethanol. Elsevier, pp. 425-448.

[188] Rahimzadeh, H., Tabatabaei, M., Aghbashlo, M., Panahi, H.K.S., Rashidi, A., Goli, S.A.H., Mostafaei, M., Ardjmand, M., Nizami, A.S., 2018. Potential of acid-activated bentonite and $\mathrm{SO}_{3} \mathrm{H}$-functionalized MWCNTs for biodiesel production from residual olive oil under biorefinery scheme. Front. Energy Res. 6, 137.

[189] Rakopoulos, D., Rakopoulos, C., Giakoumis, E., Dimaratos, A., Kyritsis, D., 2010. Effects of butanol-diesel fuel blends on the performance and emissions of a high-speed DI diesel engine. Energy Convers. Manage. 51(10), 1989-1997.

[190] Reda, T., Plugge, C.M., Abram, N.J., Hirst, J., 2008. Reversible interconversion of carbon dioxide and formate by an electroactive enzyme. Proc. Natl. Acad. Sci. 105(31), 10654-10658.

[191] Reed, T.B., Lerner, R., 1973. Methanol: A versatile fuel for immediate use. Science 182(4119), 1299-1304

[192] RFA, 2019. Annual fuel ethanol production. U.S. and world ethanol production. Renewable Fuels Association. (accessed on 21 Aug. 2019).

[193] Rittmann, B.E., McCarty, P.L., 2012. Environmental biotechnology: principles and applications. 4th ed. Tata McGraw-Hill Education, Boston, MA.

[194] Robota, H.J., Alger, J.C., Shafer, L., 2013. Converting algal triglycerides to diesel and HEFA jet fuel fractions. Energy Fuels 27(2), 985-996

[195] Romm, J.J., 2004. The hype about hydrogen: fact and fiction in the race to save the climate. Island Press, Washington, DC.

[196] Rühl, J., Schmid, A., Blank, L.M., 2009. Selected Pseudomonas putida strains able to grow in the presence of high butanol concentrations. Appl. Environ. Microbiol. 75(13), 4653-4656.
[197] Saengarun, C., Petsom, A., Tungasmita, D.N., 2017. Etherification of glycerol with propylene or 1-butene for fuel additives. Sci. World J. Article ID: 4089036

[198] Saha, B.C., Iten, L.B., Cotta, M.A., Wu, Y.V., 2005. Dilute acid pretreatment, enzymatic saccharification and fermentation of wheat straw to ethanol. Process Biochem. 40(12), 3693-3700.

[199] Sajedi, H., Mohammadipanah, F., Shariat Panahi, H.K., 2018. An image analysis-aided method for redundancy reduction in differentiation of identical actinobacterial strains. Future Microbiology 13(3), 313-329.

[200] Sarkar, N., Ghosh, S.K., Bannerjee, S., Aikat, K., 2012. Bioethanol production from agricultural wastes: An overview. Renewable Energy 37(1), 19-27.

[201] Sassner, P., Galbe, M., Zacchi, G., 2006. Bioethanol production based on simultaneous saccharification and fermentation of steampretreated Salix at high dry-matter content. Enzyme Microb. Technol. 39(4), 756-762.

[202] Scarlat, N., Dallemand, J.F., Fahl, F., 2018. Biogas: Developments and perspectives in Europe. Renewable energy 129, 457-472.

[203] Schechter, A., Teller, H., Kashyap, D., 2019. Enhanced anodic reaction of dimethyl ether (DME) on Ptpdsn based catalysts for high power low temperature fuel cells. The Electrochemical Society. pp. 1528-1528.

[204] Schelling, H., Stroefer, E., Pinkos, R., Haunert, A., Tebben, G.D., Hasse, H., Blagov, S., 2005. Method for producing polyoxymethylene dimethyl ethers, U.P. 0207954A1, Google Patents.

[205] Schwarz, W., Gapes, J., 2006. Butanol-rediscovering a renewable fuel. BioWorld Europe 1, 16-19.

[206] Searchinger, T., Heimlich, R., Houghton, R.A., Dong, F., Elobeid, A., Fabiosa, J., Tokgoz, S., Hayes, D., Yu, T.H., 2008. Use of US croplands for biofuels increases greenhouse gases through emissions from land-use change. Science 319(5867), 1238-1240.

[207] Semrau, J.D., DiSpirito, A.A., Yoon, S., 2010. Methanotrophs and copper. FEMS Microbiol. Rev. 34(4), 496-531

[208] Serov, A., Kwak, C., 2010. Recent achievements in direct ethylene glycol fuel cells (DEGFC). Appl. Catal., B. 97(1), 1-12.

[209] Shahbazi, H., Taghvaee, S., Hosseini, V., Afshin, H., 2016. A GIS based emission inventory development for Tehran. Urban Clim. $17,216-229$

[210] Shao, P., Huang, R., 2007. Polymeric membrane pervaporation. J. Membr. Sci. 287(2), 162-179.

[211] Sheets, J.P., Ge, X., Li, Y.F., Yu, Z., Li, Y., 2016. Biological conversion of biogas to methanol using methanotrophs isolated from solid-state anaerobic digestate. Bioresour. Technol. 201, 5057.

[212] Shirani, M., Ghaziaskar, H.S., Xu, C.C., 2014. Optimization of glycerol ketalization to produce solketal as biodiesel additive in a continuous reactor with subcritical acetone using Purolite ${ }^{8}$ PD206 as catalyst. Fuel Process. Technol. 124, 206-211.

[213] Shirzad, M., Kazemi Shariat Panahi, H., Dashti, B.B., Rajaeifar, M.A., Aghbashlo, M., Tabatabaei, M., 2019. A comprehensive review on electricity generation and GHG emission reduction potentials through anaerobic digestion of agricultural and livestock/slaughterhouse wastes in Iran. Renewable Sustainable Energy Rev. 111, 571-594

[214] Singh, A.P., Anbumani, K., 2011. A comparative study on the use of butyl esters of soyabean and sunflower oils as biodiesel fuel for compression ignition engine. J. Iran. Mech. Eng. 12, 68-85.

[215] Smil, V., 2001. Enriching the earth: Fritz Haber, Carl Bosch, and the transformation of world food production. MIT press, Cambridge, MA

[216] Spooner-Wyman, J.K., Appleby, D.B., Yost, D.M., 2003. Evaluation of di-butoxy glycerol (DBG) for use as a diesel fuel blend component. SAE Technical Paper. 0148-7191.

[217] Steen, E.J., Chan, R., Prasad, N., Myers, S., Petzold, C.J., Redding, A., Ouellet, M., Keasling, J.D., 2008. Metabolic engineering of Sacharomyces cerevisiae for the production of n-butanol. Microb. Cell Fact. 7(1), 36. 
[218] Stein, L.Y., Yung, Y.L., 2003. Production, isotopic composition, and atmospheric fate of biologically produced nitrous oxide. Annu. Rev. Earth Planet. Sci. 31(1), 329-356.

[219] Stocker, T.F., Qin, D., Plattner, G.K., Tignor, M., Allen, S.K., Boschung, J., Nauels, A., Xia, Y., Bex, B., Midgley, B., 2013. IPCC, 2013: Climate change 2013: The physical science basis. Contribution of working group I to the fifth assessment report of the intergovernmental panel on climate change, Cambridge University Press.

[220] Stockes, K., 2007. Ammonia construction record and comments on ammonia fuel. Proc. of the Ammonia-Sustainable, Emission Free Fuel Conference, October 15-16.

[221] Strickland, G., 1981. Ammonia as a hydrogen energy-storage medium. 5th annual thermal storage meeting, Paper 8010555-2 10th October 1980, VA, USA. McLean.

[222] Su, Z., Ge, X., Zhang, W., Wang, L., Yu, Z., Li, Y., 2017. Methanol production from biogas with a thermotolerant methanotrophic consortium isolated from an anaerobic digestion system. Energy Fuels 31(3), 2970-2975.

[223] Subramani, V., Gangwal, S.K., 2008. A review of recent literature to search for an efficient catalytic process for the conversion of syngas to ethanol. Energy Fuels 22(2), 814-839.

[224] Swings, J., De Ley, J., 1977. The biology of Zymomonas. Bacteriol. Rev. 41(1), 1.

[225] Szczodrak, J., Fiedurek, J., 1996. Technology for conversion of lignocellulosic biomass to ethanol. Biomass Bioenergy 10(5-6), 367375.

[226] Sze, M.C., 1966. Manufacture of aqueous formaldehyde solution and paraformaldehyde. United State Patent US3277179A.

[227] Tabatabaei, M., Aghbashlo, M., Dehhaghi, M., Kazemi Shariat Panahi, H., Mollahosseini, A., Hosseini, M., 2019a. Reactor technologies for biodiesel production and processing: A review. Prog. Energy Combust. Sci. 74, 239-303.

[228] Tabatabaei, M., Aghbashlo, M., Valijanian, E., Hamed, K.S.P., Nizami, A.S., Ghanavati, H., Sulaiman, A., Mirmohamadsadeghi, S., Karimi, K., 2019b. A comprehensive review on recent biological innovations to improve biogas production, part 2: Mainstream and downstream strategies. Renewable Energy 146, 1204-1220.

[229] Taher, E., Chandran, K., 2013. High-rate, high-yield production of methanol by ammonia-oxidizing bacteria. Environ. Sci. Technol. 47(7), 3167-3173

[230] Takeguchi, M., Furuto, T., Sugimori, D., Okura, I., 1997. ptimization of methanol biosynthesis by Methylosinus trichosporium OB3b: An approach to improve methanol accumulation. Appl. Biochem. Biotechnol. 68(3), 143-152.

[231] Tampier, M., Smith, D., Bibeau, E., Beauchemin, P., 2004. Identifying environmentally preferable uses for biomass resources. Environmental Services Inc.

[232] Temchin, J., 2003. Analysis of market characteristics for conversion of liquid fueled turbines to methanol. The Methanol Foundation and Methanex, Inc.

[233] Theisen, A.R., Murrell, J.C., 2005. Facultative methanotrophs revisited. J. Bacteriol. 187(13), 4303-4305.

[234] Thomas, G., Parks, G., 2006. Potential roles of ammonia in a hydrogen economy: a study of issues related to the use ammonia for on-board vehicular hydrogen storage. US Department of Energy.

[235] Tomas, C.A., Welker, N.E., Papoutsakis, E.T., 2003. Overexpression of groESL in Clostridium acetobutylicum results in increased solvent production and tolerance, prolonged metabolism, and changes in the cell's transcriptional program. Appl. Environ. Microbiol. 69(8), 49514965 .

[236] Ujor, V., Okonkwo, C., Ezeji, T.C., 2016. Unorthodox methods for enhancing solvent production in solventogenic Clostridium species. Appl. Microbiol. Biotechnol. 100(3), 1089-1099.

[237] United Nations, 2015. Climate action now.

[238] USEPA, 2012. Energy projects and candidate landfills. Landfill methane outreach program. USEPA. Washington DC.

[239] Uyttebroek, M., Van Hecke, W., Vanbroekhoven, K., 2015. Sustainability metrics of 1-butanol. Catal. Today 239, 7-10.
[240] Van Blarigan, P., 2000. Advanced internal combustion engine research. DOE Hydrogen Program Review NREL/CP-570-28890.

[241] Vane, L.M., 2005. A review of pervaporation for product recovery from biomass fermentation processes. J. Chem. Technol. Biotechnol. 80(6), 603-629.

[242] Vicente, G., Melero, J.A., Morales, G., Paniagua, M., Martín, E., 2010. Acetalisation of bio-glycerol with acetone to produce solketal over sulfonic mesostructured silicas. Green Chem. 12(5), 899-907.

[243] Vidal, J., 2015. World leaders urged to cut air pollution to save lives in poor countries International edition: The Guardian.

[244] Voelcker, J., 2015. 1.2 billion vehicles on world's roads now, 2 billion by 2035: report, in: Green car reports. Vol. 7, pp. 14

[245] Walker, M., Iyer, K., Heaven, S., Banks, C., 2011. Ammonia removal in anaerobic digestion by biogas stripping: an evaluation of process alternatives using a first order rate model based on experimental findings. Chem. Eng. J. 178, 138-145.

[246] Wang, Z., Zhuge, J., Fang, H., Prior, B.A., 2001. Glycerol production by microbial fermentation: A review. Biotechnol. Adv. 19(3), 201-223

[247] WBA, 2018. WBA global bioenergy statistics 2018. World Bioenergy Association- The Global Voice of Bioenergy.

[248] Weiss, K., 2013. Commercialization of a renewable aviation fuel industry in brasil. Contribution to Ethanol Summit. June 2013, Sao Paulo.

[249] Wendt, J., Sternling, C., 1974. Effect of ammonia in gaseous fuels on nitrogen oxide emissions. J. Air Pollut. Control Assoc. 24(11), $1055-1058$

[250] Westbrook, C.K., Pitz, W.J., Curran, H.J., 2006. Chemical kinetic modeling study of the effects of oxygenated hydrocarbons on soot emissions from diesel engines. J. Phys. Chem. A. 110(21), 69126922.

[251] Whitehead, T.R., Cotta, M.A., 2004. Isolation and identification of hyper-ammonia producing bacteria from swine manure storage pits. Curr. Microbiol. 48(1), 20-26.

[252] Widmar D., 2019. Higher fertilizer prices in 2019. Agricultural economic insights. (accessed on 22 Aug. 2019).

[253] Wollrab, A., 2009. Organische chemie. (ed.), Eine Einführung für Lehramts- und Nebenfachstudenten, Springer Berlin Heidelberg. Berlin, Heidelberg.

[254] Wood, B.E., Ingram, L., 1992. Ethanol production from cellobiose, amorphous cellulose, and crystalline cellulose by recombinant Klebsiella oxytoca containing chromosomally integrated Zymomonas mobilis genes for ethanol production and plasmids expressing thermostable cellulase genes from Clostridium thermocellum. Appl. Environ. Microbiol. 58(7), 2103-2110.

[255] World Bank, 2016. The cost of air pollution: strengthening the economic case for action. World Bank and Institute for Health Metrics and Evaluation.

[256] Wright, M.E., Harvey, B.G., Quintana, R.L., 2008. Highly efficient zirconium-catalyzed batch conversion of 1-butene: A new route to jet fuels. Energy Fuels 22(5), 3299-3302.

[257] Xin, F., Yan, W., Zhou, J., Wu, H., Dong, W., Ma, J., Zhang, W., Jiang, M., 2018. Exploitation of novel wild type solventogenic strains for butanol production. Biotechnol. Biofuels 11(1), 252.

[258] Yang, L., Zhu, Z., Wang, W., Lu, X., 2013. Microbial recycling of glycerol to biodiesel. Bioresour. Technol. 150, 1-8.

[259] Yang, S., Fei, Q., Zhang, Y., Contreras, L.M., Utturkar, S.M., Brown, S.D., Himmel, M.E., Zhang, M., 2016. Zymomonas mobilis as a model system for production of biofuels and biochemicals. Microb. Biotechnol. 9(6), 699-717.

[260] Yeh, T.M., Dickinson, J.G., Franck, A., Linic, S., Thompson, L.T., Savage, P.E., 2013. Hydrothermal catalytic production of fuels and chemicals from aquatic biomass. J. Chem. Technol. Biotechnol. 88(1), 13-24.

[261] Zamfirescu, C., Dincer, I., 2009. Ammonia as a green fuel and hydrogen source for vehicular applications. Fuel Process Technol. 90(5), 729-737

[262] Zhang, W., Ge, X., Li, Y.F., Yu, Z., Li, Y., 2016. Isolation of a methanotroph from a hydrogen sulfide-rich anaerobic digester for 
methanol production from biogas. Process Biochem. 51(7), 838-844.

[263] Zheng, Y., Tang, Q., Wang, T., Liao, Y., Wang, J., 2013. Synthesis of a green fuel additive over cation resins. Chem. Eng. Technol. 36(11), 1951-1956.

[264] Zheng, Y.J., Bruice, T.C., 1997. Conformation of coenzyme pyrroloquinoline quinone and role of $\mathrm{Ca}^{2+}$ in the catalytic mechanism of quinoprotein methanol dehydrogenase. Proc. Natl. Acad. Sci. 94(22), 11881-11886.

[265] Zhu, H., Liu, G., Yuan, J., Chen, T., Xin, F., Jiang, M., Fan, Y., Jin, W., 2019. In-situ recovery of bio-butanol from glycerol fermentation using PDMS/ceramic composite membrane. Sep. Purif. Technol. 229, 115811.
[266] Zhu, R., Wang, X., Miao, H., Huang, Z., Gao, J., Jiang, D., 2008. Performance and emission characteristics of diesel engines fueled with diesel- dimethoxymethane (DMM) blends. Energy Fuels 23(1), 286-293.

[267] Zhuge, J., Fang, H., Wang, Z., Chen, D., Jin, H., Gu, H., 2001. Glycerol production by a novel osmotolerant yeast Candida glycerinogenes. Appl. Microbiol. Biotechnol. 55(6), 686-692.

[268] Zhuge, J., Liu, X., 1990. A glycerol recovery method for glycerol production by fermentation. Chinese Patent CN 1047532A.

[269] Zverlov, V., Berezina, O., Velikodvorskaya, G., Schwarz, W. 2006. Bacterial acetone and butanol production by industrial fermentation in the Soviet Union: Use of hydrolyzed agricultural waste for biorefinery. Appl. Microbiol. Biotechnol. 71(5), 587597. 